\title{
ARRANGEMENT, DESCRIPTION, AND PRESENTATION OF THE FAIRLIE FAMILY COLLECTION AT THE ART GALLERY OF ONTARIO: A CASE STUDY IN COLLECTIONS MANAGEMENT
}

by

Laura C. Gentili, BA, University of Windsor, 2012

\author{
An applied thesis project \\ presented to Ryerson University \\ in partial fulfillment of the \\ requirements for the degree of \\ Master of Arts \\ in the program of
}

Film and Photography Preservation and Collections Management

Toronto, Ontario, Canada, 2015

(c) Laura C. Gentili 2015 


\section{AUTHOR'S DECLARATION}

I hereby declare that I am the sole author of this thesis. This is a true copy of the thesis, including any required final revisions, as accepted by my examiners.

I authorize Ryerson University to lend this thesis to other institutions or individuals for the purpose of scholarly research.

I further authorize Ryerson University to reproduce this thesis by photocopying or by other means, in total or in part, at the request of other institutions or individuals for the purpose of scholarly research.

I understand that my thesis may be made electronically available to the public.

Laura C. Gentili 


\begin{abstract}
Arrangement, Description, and Presentation of the Fairlie Family Collection at the Art Gallery of Ontario:

A Case Study in Collections Management

Master of Arts, 2015

Laura C. Gentili

Film and Photography Preservation and Collections Management

Ryerson University
\end{abstract}

This thesis presents the results of an applied project in Collections Management, comprising the intellectual arrangement of the Fairlie Family fonds at the Art Gallery of Ontario (AGO), and the creation of a finding aid to facilitate future access and research. This project analyzes twelve Canadian family albums from the AGO's collection of photography that were compiled by the Fairlie family between the years of 1880 and 1950. This project is comprised of three major parts: (1) an analytical paper, (2) extensive inventories and object-level cataloguing records, and (3) the creation of a finding aid for the family documents and related ephemera.

The first part of this thesis consists of an analytical paper discussing the historical context of the albums and what they can tell us about the Fairlie family and the time and place in which they were created. The albums document the family's exploits in photography, from mining in northern Ontario, various travel destinations, summer camping in Temagami, and life in upper-middle-class Toronto during the first half of the twentieth century. The practical component of this project includes genealogical research; detailed inventories for each of the twelve albums; the intellectual arrangement, rehousing, and creation of a finding aid for the textual records and related ephemera; and updated cataloguing records linking the albums with the Fairlie Family fonds in The Museum System database (TMS) so that both the photographic collection and contextual information are more accessible. 


\section{ACKNOWLEDGMENTS}

This thesis would not have been possible without the assistance and support from many people.

I would like to thank the staff at the Art Gallery of Ontario, in particular Sophie Hackett, Amy Furness, Liana Radvak, and Sabine Shafer for their advice and continuous guidance throughout my project.

I would like to thank Max Dean for donating such a rich collection to the AGO and for taking the time to share his insight with me.

My thesis advisor, Sarah Parsons, for helping me to perfect this project.

My second reader, Jennifer Rutkair, for taking the time to read and critique this document.

A special thanks to Tam Fairlie, Gail Sjuberg at the Gulf Island Driftwood Newspaper, the University of Toronto Archives, and the Upper Canada College Archives for their assistance with this project.

Thank you to my friends and family for their ongoing support, the professors at Ryerson University in the FPPCM program, and my partner Kyle Lefaive for loving me and always pushing me to be the best I can be.

And last, but not least, thank you to the FPPCM class of 2015. I would like to extend a special thank you to Kasia Laszczuk, Carla-Jean Stokes, and Cassandra Zeppieri for their support and company throughout this long process. 
For my parents.

For their endless love, encouragement, and support. 


\section{TABLE OF CONTENTS}

Author's Declaration $\quad$ ii

Abstract $\quad$ iii

Acknowledgements iv

Dedication $\quad$ v

Table of Contents vi vi vi

List of Figures vii

PART I: ANALYTICAL PAPER 1

$\begin{array}{ll}\text { Chapter 1: Introduction } & 2\end{array}$

Chapter 2: The Max Dean Collection $\quad 5$

$\begin{array}{ll}\text { Chapter 3: Literature Survey } & 8\end{array}$

$\begin{array}{lr}\text { a. Snapshots and the Family Album } & 8\end{array}$

b. Contextual Research 11

c. Finding Aids and Collections Management Resources 13

Chapter 4: Historical Analysis $\quad 15$

PART II: PRACTICAL PROJECT 36

Chapter 5: AGO Archives and Special Collections 37

Chapter 6: Approach and Methodology 38

1. Album Inventories 38

2. Cataloguing Records 39

3. Finding Aid 40

$\begin{array}{ll}\text { Chapter 7: Conclusion } & 45\end{array}$

$\begin{array}{ll}\text { APPENDICES } & 47\end{array}$

I. Album Inventories $\quad 48$

II. TMS Cataloging Records

III. Fairlie Family Tree $\quad 62$

IV. "Photos Recall Christmas Past" by Alan F. Fairlie, November 28, 2000

V. Fairlie Family fonds Finding Aid 64

$\begin{array}{ll}\text { Bibliography } & 74\end{array}$ 


\section{LIST OF FIGURES}

Figure 1: Fairlie family album, 1930

Figure 2: Fairlie family album, c. 1910 - 1930

Figure 3: Alan's childhood album, c. 1930s

Figure 4: Alan's childhood album, c. 1930s

Figure 5: Early snapshots taken in the UK, c. 1880- 1905

Figure 6: Early experiments in photography, c. 1905

Figure 7: Picturesque Silverland, 1922

Figure 8: Mining scenes and equipment, c. 1903 - 1915

Figure 9: The Cobalt Song, c. 1910

Figure 10: Miners with their cameras, Cobalt, Ontario, c. 1910

Figure 11: Interior shots of the Fairlie's home in Cobalt, 1929

Figure 12: Matthew in a brand new Buick, c. 1930

Figure 13: Alan and Joyce at Christmas, 1938

Figure 14: Joyce and Alan in their school uniforms, 1939

Figure 15: Alan's Camp Temagami album, 1936

Figure 16: Alan and Joyce, Toronto, 1938

Figure 17: Vacationing in Rostrevor, 1939

Figure 18: Vacationing in Temagami, 1939

Figure 19: Matthew's camping trip, c. 1930s

Figure 20: Alan's Scrapbook, "The Personal Record of a Good Will Ambassador," 1950

Figure 21: Experimenting with silhouettes, c. 1930s

Figure 22: Film poster for "Ageless Britain," filmed and narrated by Alan F. Fairlie, c. 1950

Figure 23: Film poster for "Alpine Europe," filmed and narrated by Alan F. Fairlie, c. 1950

Figure 24: Alan with his camera, Ektachrome transparency, c. 1950

Figure 25: Intellectual arrangement of the Fairlie Family fonds

All photographs are courtesy of the Art Gallery of Ontario. 
PART I

ANALYTICAL PAPER 


\section{CHAPTER 1: INTRODUCTION}

Since the invention of photography, people have eagerly used the medium to record themselves, their history, their country, and their culture. The introduction of the portable fixed-focus camera in the late nineteenth century brought photography into the lives of everyday people who were able to make their own photographs and compile them into albums. ${ }^{1}$ For the first time in history, ordinary people were given the opportunity to make pictures as they pleased, free of any professional training or technical expertise. ${ }^{2}$

The Fairlies were one of the millions of families inspired by photography, using the medium to capture and record their experiences and their lives.

This study examines the organization, contents, and significance of the Fairlie collection at the Art Gallery of Ontario (AGO). The collection, compiled between the years of 1880 and 1950, consists of twelve vernacular albums and two boxes of related family documents and ephemera. ${ }^{3}$ It was donated to the AGO in 2012 by Toronto-based artist Max Dean as part of a larger acquisition of over 200 albums. What is significant to this collection is not only the images, but also the entire practice of photography as the Fairlie family saw it; their participation in and experience with the medium. ${ }^{4}$ The value of a collection such as this lies in its size. Having access to a number of albums compiled by the same family creates an opportunity to trace their use of the medium over time. Taken together, the albums offer insight into the first generation of photographic storytelling, documenting changes in photographic technology and responses to

\footnotetext{
${ }^{1}$ Barbara Levine and Stephanie Snyder, Snapshot Chronicles: Inventing the American Photo Album (New York: Princeton ${ }^{2}$ Douglas R. Nickel, Snapshots: The Photography of Everyday Life, 1888 to the Present (San Francisco: San Francisco Museum of Modern Art, 1998), 10. For the purpose of this study, "technical expertise and professional training" refers to the ability early practitioners had in operating cameras, chemically sensitizing plates, developing their own negatives in a darkroom, and executing successful photographic prints on their own.

${ }^{3}$ It should be noted that the initial collection contained fourteen albums; however, after extensive research I have concluded that the Fairlie family only compiled twelve of the albums. Another family from Toronto compiled the remaining two albums in the collection. For the purpose of this thesis, only the twelve will be analyzed.

${ }^{4}$ Sophie Hackett Gift Seeking Certification from the Canadian Cultural Property Export Review Board, Research Report (Toronto: AGO, Research Report, February 2012).
} 
industrialization, urban growth, and modern life. The albums also provide information about the past and are worthy of study because of what they can reveal to us about a specific time and place in Canadian history.

Reverend John (1844-1919) and Hannah Fairlie (c. 1847-1929) immigrated to Canada in the midnineteenth century from Scotland. One of their nine children, Matthew Fraser Fairlie (1883-1944), attended Queens University in Kingston and later moved to Cobalt, Ontario with his wife Anne Louise (c. 1881-1961) to work as a Mining Engineer during the Silver Rush of 1903. They moved to Toronto in the late 1920s, purchased a house in Forest Hill, adopted two children-Joyce (1929-1956) and Alan (19272001) - and continued to have connections to the mining industry, the Canadian Pacific and National Railways, and the growing financial district of Toronto. The albums depict the family's exploits in photography including mining in northern Ontario, various travel destinations, summer camping in Temagami, and life in upper-middle-class Toronto during the first half of the twentieth century. The collection also includes two boxes of family documents and related ephemera, consisting of letters to and from family members, passports, notebooks and diaries, newspaper clippings, birth certificates, and assorted photographs and negatives. As social and cultural documents, these materials portray various aspects of Canadian life, depicting events, activities, and places significant to both the city of Toronto and the province of Ontario.

The reasons for undertaking this project are to facilitate access to the collection, to provide it with a historical context, and to gain practical knowledge of archival and collections management practices. While the primary focus of this thesis is practical, secondary contextual and historical research has also been carried out in order to provide a framework for better understanding this body of work. The objective of this thesis is to provide the AGO with a comprehensive record of the materials in order to make them more accessible to staff and researchers. This thesis is divided into two major parts: Part I is an analytical paper 
that includes a survey of relevant research on the topic, a section discussing the provenance of the collection, and a historical analysis that traces the family's use of photography during the period in question. Part II is a practical project that addresses collections management concerns. It includes sections discussing my approach and methodology, as well as information on the AGO's Archives and Special Collections. Moreover, the project includes twelve album inventories, TMS cataloguing records, genealogical research, and a finding aid for the supporting family documents and related ephemera.

Each album in the Fairlie collection provides a unique study of visual communication, expressing a story of the compiler, those portrayed, and the time and place in which they lived. ${ }^{5}$ The albums not only represent a significant period in the history of photography when the medium was first introduced into everyday life, but they also chronicle a significant portion of Canadian history, documenting family life from the late nineteenth century to the 1950s. Each album presents views that are unique to members of the Fairlie family, portraying the aspects of their lives that they believed to be most worthy of recording.

A comprehensive study such as this can be used as a framework for better understanding family albums in a Canadian context. Furthermore, this thesis provides a case study for researching and interpreting photographic albums, raising questions concerning the various narratives and typologies that albums present and how they can be linked to larger social and cultural histories. If we better understood the provenance and historical context behind the collection, we could then better understand its significance and why it is important to make these materials more accessible. Through conducting historical research, cataloguing, compiling inventories, and both intellectually and physically organizing the materials, the project has helped to create an identity for the collection at the AGO.

\footnotetext{
${ }^{5}$ Steven Kramer, "Robert C. Kraut's Japan: Cataloguing and Contextualizing post-World War Two Photographic Albums of Japan and the South Pacific"(Master's thesis, Ryerson University, 2013), 9.
} 


\section{CHAPTER 2: THE MAX DEAN COLLECTION}

Over a ten-year period-from approximately 1992 to 2012-Toronto artist Max Dean amassed a collection of over 600 photographic albums. ${ }^{6}$ Through a project called Max Dean: Album, which was developed by the AGO in partnership with the 2012 Scotiabank CONTACT Photography Festival, Dean used his collection of family albums to question the changing nature of photographic objects and to consider what meanings they held as collectibles. As part of his project, Dean passed the albums that he collected on to willing new owners, giving the "orphaned" albums a new context and a new meaning. Regardless of their context, whether public or private, albums present visual narratives and function as "vehicle[s] for storytelling." ${ }^{8}$ These are some of the reasons that lead Dean to collect so many of them.

When Dean began collecting albums in the early 1990s, his original intention was to disassemble them and use the photographs as part of a project he called As Yet Untitled (1992-1995). The piece consisted of an industrial robot that was programmed to pick up a family photograph and present it to the viewer. ${ }^{9}$ The viewer could choose to save it—at which point the robotic arm would deposit it into an archival box-or not save it—which allowed the robot to insert the photograph into a paper shredder. ${ }^{10}$ Through his work, Dean left it up to the viewer to determine the fate of these found family photographs. While searching for material for his project at the Pike Place Market in Seattle, Dean purchased some of his first family albums. After carefully examining the albums in his hotel room, Dean decided that there was no way he could possibly disassemble them. As he said, "photo albums are the one, and possibly only story, many of us write."11 The power of the images and the intimacy of the narratives from people that he had never met inspired Dean, and so his collection began.

\footnotetext{
${ }^{6}$ Hackett, Gift Seeking Certification from the Canadian Cultural Property Export Review Board, Research Report.

${ }^{7}$ Heather Rigg, "The Public Lives of Private Family Albums: A Case Study in Collections and Exhibitions at the Art Gallery of Ontario and Max Dean: Album” (Mater's thesis, Ryerson University, 2012), 17.

${ }^{8}$ Ibid., 17-19.

${ }^{9}$ This sculpture by Dean is currently part of the AGO's permanent collection.

${ }^{10}$ Robert Enright, “The Certainty of Machines: An Interview with Max Dean,” Border Crossings, no. 101, (2007), accessed May 16, 2015, http://bordercrossingsmag.com/article/the-certainty-of-machines-an-interview-with-max-dean ${ }^{11}$ Ibid.
} 
After years of collecting albums from various places, Dean realized that he had more albums than he could properly care for; it was time for him to pass on the custodianship to others. Dean began by allowing Maia Sutnik and Sophie Hackett—curators of photography at the AGO—to carefully look through his collection and choose albums that they felt were historically and visually interesting. Their selection, which eventually totaled over 200 albums, would find a new home at the AGO.

The Fairlie collection was of particular interest to Dean because of its size and rarity. He was drawn to the collection because it not only included a number albums that were created and collected by one single family, but it also contained personal documents and materials that offered information about their lives. Although Dean does not remember exactly where he acquired the collection, he believes that whomever he got it from "scooped it up" at a content sale somewhere in Toronto. ${ }^{12}$ A collection such as this is unique in that it includes multiple albums from one family, allowing viewers to trace their photographic practice to determine what each generation found photo-worthy in its time. ${ }^{13}$ As part of this project, it is important to note that supporting materials such as the ones included with Dean's donation, are not always self-evident and, in most cases, require analysis in order to gain further insight. A large portion of the historical information and family research that is included as part of this project was discovered by carefully examining the collection of supporting materials and documents.

The twelve albums in the Fairlie collection were from a total of 237 albums that the AGO selected to acquire for the museum's collection and is the largest concentration of albums within the larger donation. ${ }^{14}$ The Fairlie albums were selected for their uniqueness and historical content, as being representative of Toronto and Ontario. ${ }^{15}$ Having access to the albums and the information contained within them, as well as the supporting documents, was interesting to Hackett because these materials could assist in contextualizing the collection at the AGO. Moreover, they provided a biographical element that

\footnotetext{
${ }^{12}$ Max Dean, interview by the author, April 29, 2015.

${ }^{13}$ Hackett, Gift Seeking Certification from the Canadian Cultural Property Export Review Board, Research Report.

${ }^{14}$ Ibid.

${ }^{15}$ Sophie Hackett, interview by the author, May 5, 2015.
} 
may not have been possible otherwise. The related documents and textual records provide a framework for piecing together the Fairlie family's story.

Dean's projects raise questions about family albums and snapshots and the meanings that these objects have once they are removed from their original context. If they do hold value outside of the living memory of those who took them, what kind of meaning are we to assign to them today? ${ }^{16}$ When private objects become public documents, personal memories are revealed, allowing us to better understand how a particular group of people during a particular time chose to document their lives. Discussing the provenance of the Fairlie collection allows us to better understand the role and function of these materials as part of a public institution - why they are significant and what information they can offer to us.

Researching where the Fairlie albums came from and how they became part of the AGO's collection is an essential part of tracing their past and providing them with meaning today.

\footnotetext{
${ }^{16}$ Vid Ingelevics, “Damage Done: Materializing the Photographic Image,” Prefix Photo, no. 11 (Spring/Summer 2005$): 48$.
} 


\section{CHAPTER 3: LITERATURE SURVEY}

This literature survey takes an interdisciplinary approach to the study of vernacular photography and family albums, encompassing work from a variety of perspectives. The review begins with an examination of texts written about the history of the snapshot, as well as sources that examine the use of these photographs in family albums. Emphasis is placed on critical literature that examines the social history of the photographic album and the role of these objects in public spaces. Moreover, this survey discusses texts written about the social history of Canada, specifically addressing the northern Ontario frontier, the city of Toronto, and family life in Canada from the late nineteenth century to the 1950s. The survey concludes with a review of collections management resources, including texts written about archival practices and the creation and use of finding aids.

\section{A. SNAPSHOTS AND THE FAMILY ALBUM}

Although snapshot photography is not the primary focus of this study, the following research has been conducted in order to better understand how the evolution of the genre influenced the use of the family album and vice versa. Until the last two decades of the twentieth century, the amateur snapshot was rarely discussed in works on photography. ${ }^{17}$ An exception to this is Brian Coe and Paul Gates' The Snapshot Photograph: The Rise of Popular Photography, 1888-1939 published in $1977 .{ }^{18}$ The authors address the development of the snapshot over the period in question, discussing the social and technological impacts of the first Kodak camera. ${ }^{19}$ This is a useful resource because not only does it trace the changes in camera technology that occurred between 1888 and 1939, but it also addresses the ways in which these developments affected the entire practice of photography in the everyday. Unfortunately, the authors do

\footnotetext{
${ }^{17}$ Anna Krentz, “Snapshots with an Edge: A Study of Deckled Edge in the North American Snapshot” (Master's thesis, Ryerson University, 2009), 4.

${ }^{18}$ This book, comprised of 46 pages of illustrated text and another 90 of captioned images, draws from the collection of the British Kodak Museum, which has since been absorbed into the National Media Museum.

${ }^{19}$ Brian Coe and Paul Gates, The Snapshot Photograph: The Rise of Popular Photography, 1888-1939 (London: Ash \& Grant Publishing, 1977), 16.
} 
not analyze any photographs in great detail for their social or cultural implications. Although this text presents relevant information on the early history of the snapshot, recent literature written on the topic provides a more in-depth examination of this type of photography as it exists in a contemporary context.

The Art of the American Snapshot, 1888-1978 was published in 2007 to accompany an exhibition at the National Gallery of Art. ${ }^{20}$ The book traces the evolution of snapshot imagery and describes how different technical, social, and cultural factors affected the look of snapshots at different periods. In the introduction, curator Sarah Greenough emphasizes that the subjects, approaches, and styles of the snapshot "have evolved over time in response to changing technologies and cultural influences." ${ }^{21}$ The history of the snapshot is divided into chronological periods, each generation discussing significant trends, technologies, and wider social histories. As Greenough points out, it is important to consider the ways in which this type of photography corresponded with and responded to significant moments and events throughout history. Similar ideas are explored in the essays from Now Is Then: Snapshots from the Maresca Collection, published in 2008 alongside an exhibition at the Newark Museum. The writings in this text emphasize the importance of the social and cultural contexts in which snapshots and vernacular objects are produced..$^{22}$ Marvin Heiferman's essay, "Now is Then: The Thrill and Fate of Snapshots," emphasizes the significance of the social, cultural, and visual contexts in the creation of snapshots, using the 1920s and 1930s as a case study. Although he does not tie his discussion to any specific photographs or body of photographs, he is successful at studying snapshots within the context of the time period in which they were created, drawing attention to pivotal moments in history such as women's rights, immigration, rising salaries, new fashion trends, and the rise of capitalism. Geoffrey Batchen's essay in the same book, titled "From Infinity to Zero," also emphasizes the importance of the context in which snapshots were made and discusses how this

\footnotetext{
${ }^{20}$ Sarah Greenough et al., The Art of the American Snapshot, 1888-1978: From the Collection of Robert E. Jackson (Washington: National Gallery of Art, 2007).

${ }^{21}$ Ibid., 6.

${ }^{22}$ Now is Then: Snapshots from the Maresca Collection features 150 images from the 1920s through the 1960s that have been selected from a collection of nearly 600 snapshots assembled by Frank Maresca.
} 
information can be linked to different social histories. Batchen argues that snapshots are fascinating because they become open to new and varied interpretations after they are removed from their original context. Although the snapshot is a photographic image that tends to be predictable in appearance and style, Batchen states that as a cultural phenomenon, the snapshot is a complex social device that is full of information about the past. ${ }^{23}$ Forget Me Not: Photography and Remembrance was also written by Batchen and published in 2004. This text analyzes the various ways in which vernacular photography has been used throughout history to preserve memory. In a section dedicated specifically to the family album, Batchen discusses how these objects function as vehicles of information that allow individuals and families to express their social rituals, personal dreams, and project memories in a tangible, visual form.

Martha Langford's 2001 book, Suspended Conversations: The Afterlife of Memory in Photographic Albums, is based on a collection of Canadian family albums compiled between 1860 and 1960 and held at the McCord Museum of Canadian History. In this text, Langford discusses how photographic albums tell intimate and revealing stories about people and families and how these stories can be related to oral narratives. Langford's study focuses on albums that have what she calls an "afterlife," existing in a new domain - the public space of the museum. She states that photographic images, made by others for various purposes, contain historical and cultural knowledge and can be linked to the ways in which photography has helped to shape notions of memory, identity, and family. ${ }^{24}$ Langford discusses particular albums from the archive, tracing family relationships, different compilers, and reoccurring images, exploring the significance of these elements to each family they represent. Although she raises interesting points and addresses the album as a three-dimensional object, Langford's purpose remains somewhat unclear, leaving readers with the question of how we are to effectively use her methodology to unlock the narratives she is suggesting. What value does Langford's framework provide for this genre of photography, and how can her method help to "unlock" the stories that exist within photographic albums?

\footnotetext{
${ }^{23}$ Geoffrey Batchen, "From Infinity to Zero," in Now is Then: Snapshots from the Maresca Collection (New York: Princeton Architectural Press, 2008).

${ }^{24}$ Martha Langford, Suspended Conversations: The Afterlife of Memory in Photographic Albums (Montreal: McGill-Queen's University Press, 2001), 15.
} 
Photographer Jo Spence and filmmaker Patricia Holland bring together a number of essays in their 1991 book, Family Snaps: The Meanings of Domestic Photography. The essays in this text examine domestic photography, identity, and the transformation of the family album into narratives of community, religion, and nation. ${ }^{25}$ Patricia Holland discusses the use of snapshots and private family albums in public collections and how this shift in context can help us to better understand various aspects of history and culture. ${ }^{26}$ Similarly, Stephanie Snyder and Barbara Levine's 2006 book, Snapshot Chronicles: Inventing the American Photo Album, explores the history and use of snapshots and photographic albums and considers what makes them worthwhile as both personal and historical objects. ${ }^{27}$ These two texts are significant sources for this project because they discuss the ways in which people have used snapshots in family albums to create and preserve social and cultural narratives. Moreover, both texts use concrete examples and theoretical analyses in order to understand the personal narratives that family albums present.

\section{B. CONTEXTUAL RESEARCH}

The following sources represent a selection of writings on Canadian identity and social history that have been significant for this project. Beyond Wilderness: The Group of Seven, Canadian Identity, and Contemporary Art was published in 2007 and edited by John O'Brien and Peter White. This book explores Canadian national identity through an analysis of the Group of Seven's landscape paintings and is one of the few sources that explore ideas of "northerness" and "wilderness" in relation to Canadian visual history. In Paul N. Walton's essay, "The Group of Seven and Northern Development," Walton draws attention to the late 1890 s as a starting point for economic and industrial growth in Ontario. ${ }^{28}$ Walton's chapter provides a historical analysis of the region and discusses how resource-extraction industries in northern Ontario helped to stimulate new urban growth in the south, especially in the rising financial

\footnotetext{
${ }^{25}$ Jo Spence and Patricia Holland, eds., Family Snaps: The Meanings of Domestic Photography (London: Virago Press Limited, 1991). This publication includes essays written by Annette Kuhn, Val Williams, Stuart Hall, Simon Watney, Joe Spence and Patricia Holland.

${ }^{26}$ Ibid., 2.

${ }^{27}$ The exhibition included approximately 70 exemplary albums spanning from 1898 to 1935.

${ }^{28}$ John O’Brien and Peter White, eds., Beyond Wilderness: The Group of Seven, Canadian Identity, and Contemporary Art (London: McGill-Queen's University Press, 2007).
} 
center of Toronto. This text, along with others written on the history of Ontario such as Robert Bothwell's A Short History of Ontario and Life in Ontario: A Social History by George P.T. Glazebrook, provide contextual information by acknowledging the northern region of Ontario and the mining industry as significant factors in contributing to Canada's identity and growing modernization in the first half of the twentieth century.

Home, Work, and Play: Situating Canadian Social History was edited by John C. Walsh and James Opp and published in 2010. The authors have organized the text into three spatial categories: home, work, and play. Each of the sections examines how these spaces were historically understood and experienced by various people in multiple contexts throughout Canadian history. The authors also discuss the ways in which these spatial experiences have contributed to defining Canadian identity for everyday people. The text includes articles written about the Canadian mining industry, Ontario summer camps, and the Canadian landscape, all of which are recurring themes throughout the Fairlie albums. This source provides relevant information for contextualizing the Fairlie albums and for better understanding the time and place in which they were created. Similar ideas are explored in The Infinite Bonds of Family: Domesticity in Canada, 1850-1940, written by historian Cynthia R. Comacchio and published in 1999. This text explores the social history of Canadian families during a time period that saw an industrial revolution, the First World War, and the Great Depression. Comacchio uses these larger historical events to trace the changes that occurred in the lives of Canadian families. This analysis of major societal events provides the basis for examining how families living and working in Canada responded and adapted to an evolving nation.

Historian Sharon Wall's 2009 book, The Nurture of Nature: Childhood, Antimodernism, and Ontario Summer Camps, 1920-55, examines the cultural meanings of "fresh air" and "wilderness" within the Ontario camping experience. This text provides a significant contribution to the study of leisure and recreation in early twentieth century Canada. In her examination, Wall discusses the Ontario camping movement during the interwar and immediate postwar years and offers insights into the ways in which Canadians struggled to find meaning in modern society. Considering a large portion of the albums in the 
Fairlie collection document summer camping experiences throughout Ontario, this text is a valuable source for understanding the importance of leisure activity for Canadians in the twentieth century.

\section{FINDING AIDS \& COLLECTIONS MANAGEMENT RESOURCES}

Enjoying Archives: What They Are, Where to Find Them, How to Use Them was written by Dave Iredale and published in 1973. This text, along with F.G. Emmison's Introduction to Archives (1978), provides useful introductions to the foundation of archival collections and practices. Although slightly outdated references, they both demonstrate the basic functions of archival procedures and discuss the progress of archives throughout history. ${ }^{29}$

Basic RAD: An Introduction to the preparation of fonds- and series- level descriptions using the Rules for Archival Description (1997) by Jeff O’Brien is a more recent publication that addresses archival collections in Canadian institutions. O'Brien's document is an easy-to-understand resource and is successful at breaking down the Rules for Archival Description (RAD) into the basic elements necessary when describing and creating a finding aid. Another useful resource is the 1998 article, Introduction to Archival Organization and Description, written by Michael J. Fox and Peter L. Wilkerson. ${ }^{30}$ In Part II the authors dedicate a section to descriptive standards and introduce the reader to the different types of finding aids that exist, elaborating in depth on cataloguing records and inventories. Moreover, the authors also provide step-by-step instructions on how to properly process, organize, and arrange materials in archival collections. These resources have been beneficial to me for both parts of my practical project: the creation of detailed inventories for each of the Fairlie albums, as well as the intellectual arrangement and archival organization of the related documents and ephemera for the finding aid.

\footnotetext{
${ }^{29}$ Danielle McAllister, "A Tour Through Scotland: A Finding Aid of Scottish Travel Photography at the Archives \& Special Collections, University of Guelph” (Master’s thesis. Ryerson University, 2010).

${ }^{30}$ Michael J. Fox and Peter L. Wilkerson, Introduction to Archival Organization and Description (Los Angeles: The Getty Information Institute, 1998).
} 
Past theses from Ryerson's Photography Preservation and Collections Management program have been extremely useful during the course of this project. Sarah L. Manco's thesis, "Finding Wolff: Intellectually Arranging the Werner Wolff Fonds at the Ryerson Image Centre," has been particularly helpful in providing a practical methodology for creating an archival finding aid. Although the Wolff collection primarily contains photographic material, Manco's approach is a useful tool of reference. Cassie Lomore's thesis, "Finding Oceania: Organizing a Collection of Oceanic Photographs and Albums at the Art Gallery of Ontario," as well as Danielle McAllister's thesis, “A Tour Through Scotland: A Finding Aid of Scottish Travel Photography at the Archives \& Special Collections, University of Guelph," have also both been useful in providing practical information on finding aids created for object-based collections. Lomore's thesis takes into account the standards used by the AGO for their photographic collections and has been a valuable resource for me in determining what standards are already in place. McAllister's thesis discusses how institutions such as Archives and Special Collections use descriptive finding aids to provide access to and information about their collections. Much like my thesis, McAllister's project specifically addresses the ways in which finding aids can help to build a greater web of connections and narratives for collections. 


\title{
CHAPTER 4: HISTORICAL ANALYSIS
}

\author{
"The family album is a hybrid novel- \\ a saga, a chronicle, a life story, an autobiography, \\ a legend, a photo-romance..."
}

\author{
- Anne-Marie Garat \\ Translated from Photos de Familles, 1994
}

The albums discussed as part of this thesis tell the story of Alan Fraser Fairlie and his family. They were compiled over a seventy-year period-from approximately 1880 to 1950 -and document the Fairlie family's life over the period in question. The photographer and maker of each album vary, but as modes of communication they can be interpreted as a whole, representing a chronological narrative of everyday life. What can these albums tells us about the Fairlie family and the time period in which they were created? In order to answer these questions, the albums must be analyzed for the historical and visual narratives they present. It is in the unassuming images - the family photographs, the images of domestic objects and daily life- that we can find clues to the identity of their makers and the society in which they function. ${ }^{31}$

The albums in the Fairlie collection represent a significant time in the history of photography when the medium was first introduced into everyday life. George Eastman launched the Kodak hand camera in 1888, preloaded with a roll of paper negatives and advertised with the slogan, "You press the button, we do the rest." ${ }^{32}$ By simplifying both the camera and the film processing for the consumer, Eastman made photography accessible to millions of people who could produce pictures without the need of any professional training or technical expertise. As a result, the snapshot was born and photography quickly grew into a cultural phenomenon. ${ }^{33}$ For the first time, people were able to use the medium to document their everyday lives-important events, travels and holidays, family members and pets, cars, and houses.

\footnotetext{
${ }^{31}$ Susan Close, Framing Identity: Social Practices of Photography in Canada (Winnipeg: Arbeiter Ring Publishing, 2008), xviii.

${ }^{32}$ George Eastman used this slogan to market the No. 1 Kodak camera. After the customer used all 100 exposures, they could send the camera to Rochester, New York for processing and printing.

${ }^{33}$ A snapshot is popularly defined as a type of photograph that is taken spontaneously and quickly. As Brian Coe and Paul Gates point out in The Snapshot Photograph: The Rise of Popular Photography, the very idea of the snapshot is connected to hunting-a snapshot was a shooting term applied to photography by Sir John Herschel.
} 
More importantly, it became possible for people to capture and preserve their memories in a tangible, visual form.

The family album also played a powerful role in people's lives, as it became the format through which people could arrange and sequence their snapshots in order to form narratives and express ideas of personal identity. Albums came onto the market as photography became more available and affordable. In the 1860s, prior to the introduction of the hand-held camera and the invention of the snapshot, photographic albums were mass-produced with slots designed to hold standardized photographs such as cartes-de-visite or cabinet cards. ${ }^{34}$ The design of the photographic album continued to evolve in order to keep up with changing technology. The introduction of the Kodak camera in the late nineteenth century allowed for a more available and accessible medium and, as a result, albums were created that better suited the informal nature of the snapshot. ${ }^{35}$ As people began to take their own pictures and compile them into albums, photography became an intimate, personal, and expressive practice. ${ }^{36}$ Amateur photographers were inspired and empowered to capture their experiences on film—to record life not necessarily as it was lived, but as they wished to present $\mathrm{it}^{37}$ Photography soon became an essential social practice for recording and celebrating the family during the transition into industrial modern society. ${ }^{38}$ The albums in the Fairlie collection and the snapshots contained within them represent the shared experiences that were transforming Canadian life at the turn of the century. Within these albums we encounter responses to industrialization and modernization, technological innovation, and family life (fig. 1 and fig. 2).

\footnotetext{
${ }^{34}$ Martha Langford, Telling Pictures and Showing Stories: Photographic Albums in the Collection of the McCord Museum of Canadian History (Montreal: McCord Museum of Canadian History, 2005). A carte-de-visite (CDV) is a small photograph (an albumen print approximately $11.4 \times 6.4 \mathrm{~cm}$ ) individually mounted on a calling card. The form was originally conceived for portraiture; however, there have been other uses throughout history. Also used primarily for portrait photography, cabinet cards were similar to CDVs, only larger (approximately 15.9 x $10.8 \mathrm{~cm}$ ).

${ }^{35}$ Elizabeth Siegel, Galleries of Friendship and Fame: The History of Nineteenth-Century American Photograph Albums (Connecticut: Yale University Press, 2010), 8-10.

${ }^{36}$ Philip Stokes, "The Family Photograph Album: So Great a Cloud of Witnesses," in The Portrait Photograph, ed. Graham Clarke, (Seattle: University of Washington Press, 1992), 194.

${ }^{37}$ Nickel, Snapshots: The Photography of Everyday Life, 42.

${ }^{38}$ Close, Framing Identity: Social Practices of Photography in Canada, 101.
} 
The Fairlie albums represent narratives that are not only personal, but that also reflect and embody various aspects of Canadian culture and society from the late nineteenth century to the $1950 \mathrm{~s}^{39}$

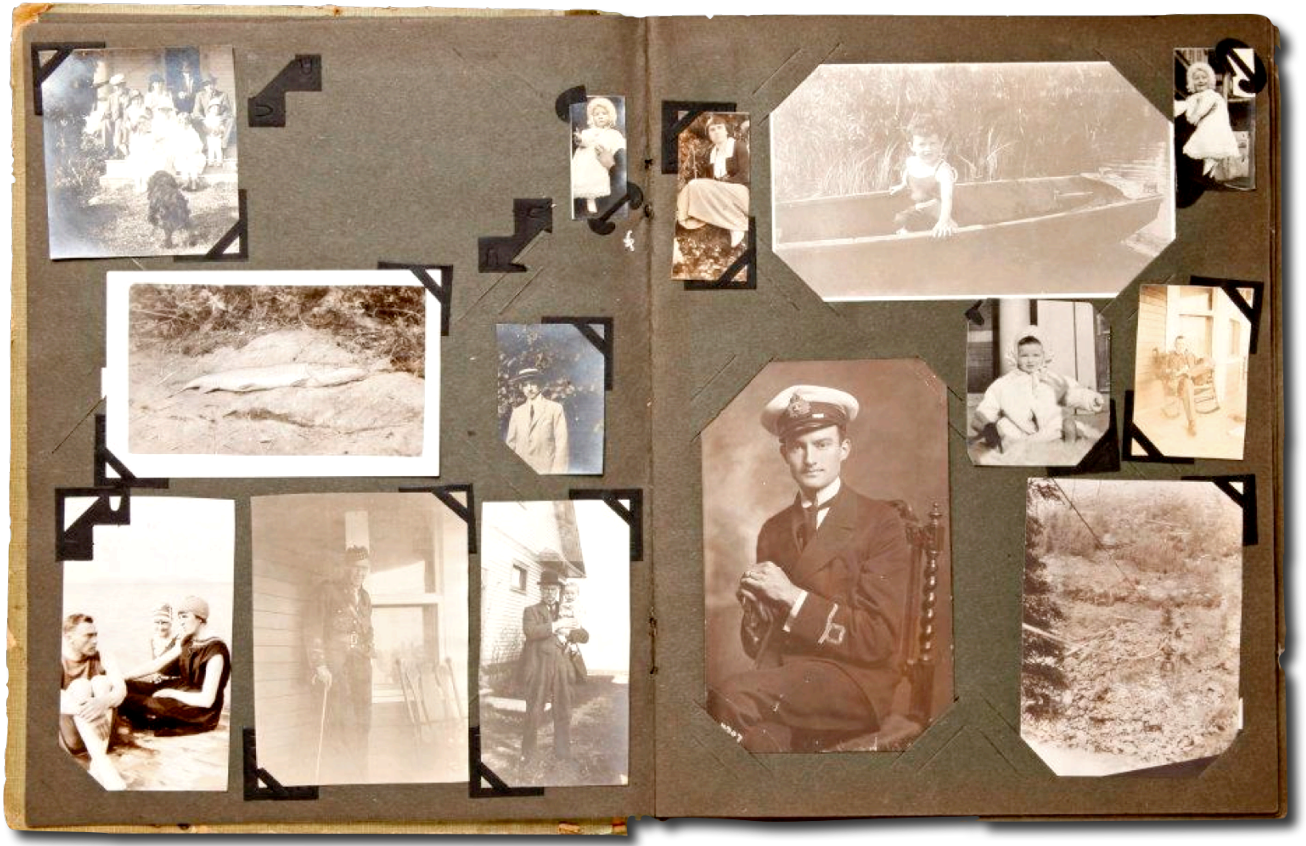

Fig. 1. Fairlie family album, 1930

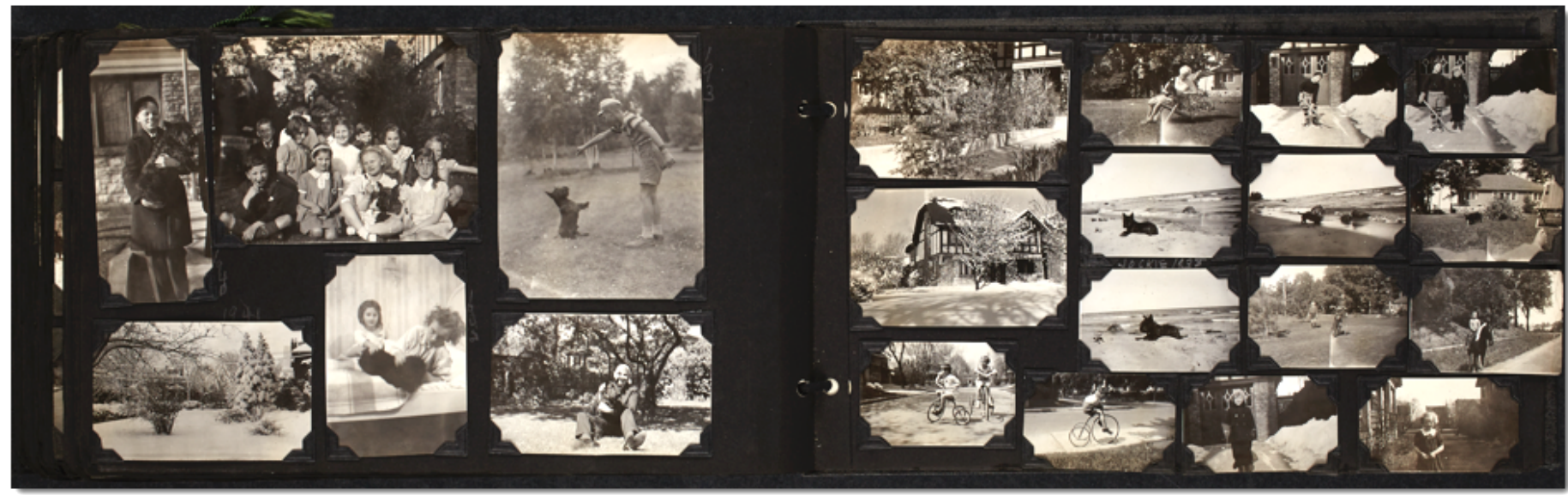

Fig. 2. Fairlie family album, c. 1910-1930

Alan Fairlie's passion for photography began at a young age. As he stated in an article he wrote for The Barnacle newspaper in 2000: “At age six, I was given a Kodak Baby Brownie for Christmas... [and] it just took off from there!" ${ }^{\prime 0}$ He was first introduced to the medium by his father and continued to practice photography into the later years of his life. His nephew Tam Fairlie recalls one visit in particular with his

\footnotetext{
${ }^{39}$ Levine and Snyder, Snapshot Chronicles, 25.

${ }^{40}$ Article courtesy of The Salt Spring Island Driftwood. The Barnacle was a local newspaper in Salt Spring Island, British Columbia, where Alan retired to later in life. He wrote a column called "Senior's Scene," which will be discussed further at the end of the chapter.
} 
uncle: "He pulled out two big stacks of vintage photographs from his pant's pockets. Alan was definitely the photographer of the family." ${ }^{41}$ Research suggests that Alan Fairlie began collecting his family's photography albums in the 1940s, but as a young boy he was always experimenting with the camera, taking photographs during vacations and holidays, school events, camping experiences, and life in the city. He also took many photographs of his sister Joyce and their dogs Jockie, Angus, and Kiltie. Alan compiled a number of the albums in the collection as a boy, with the assistance of his mother and father. An example of this can be seen in an album from the late 1930s where Alan used a pencil to inscribe his name on the front cover of the small leather book (AGO.102897). The last few pages of this album contain a number of imagesapproximately $2 \times 3$ inches in size-that have been collaged onto a single page using small black photocorners. The photographs in these sequences have been taken with a No. 2 Kodak Brownie camera and depict Alan and Joyce riding bikes in their neighborhood, out-of-focus images of their dogs, and photographs taken from Alan's bedroom window in Toronto documenting various "morning scenes," as he calls them [fig. 3 and fig. 4]. ${ }^{42}$ It is evident that Alan had a passion for photography and enjoyed playfully sequencing his pictures into albums.

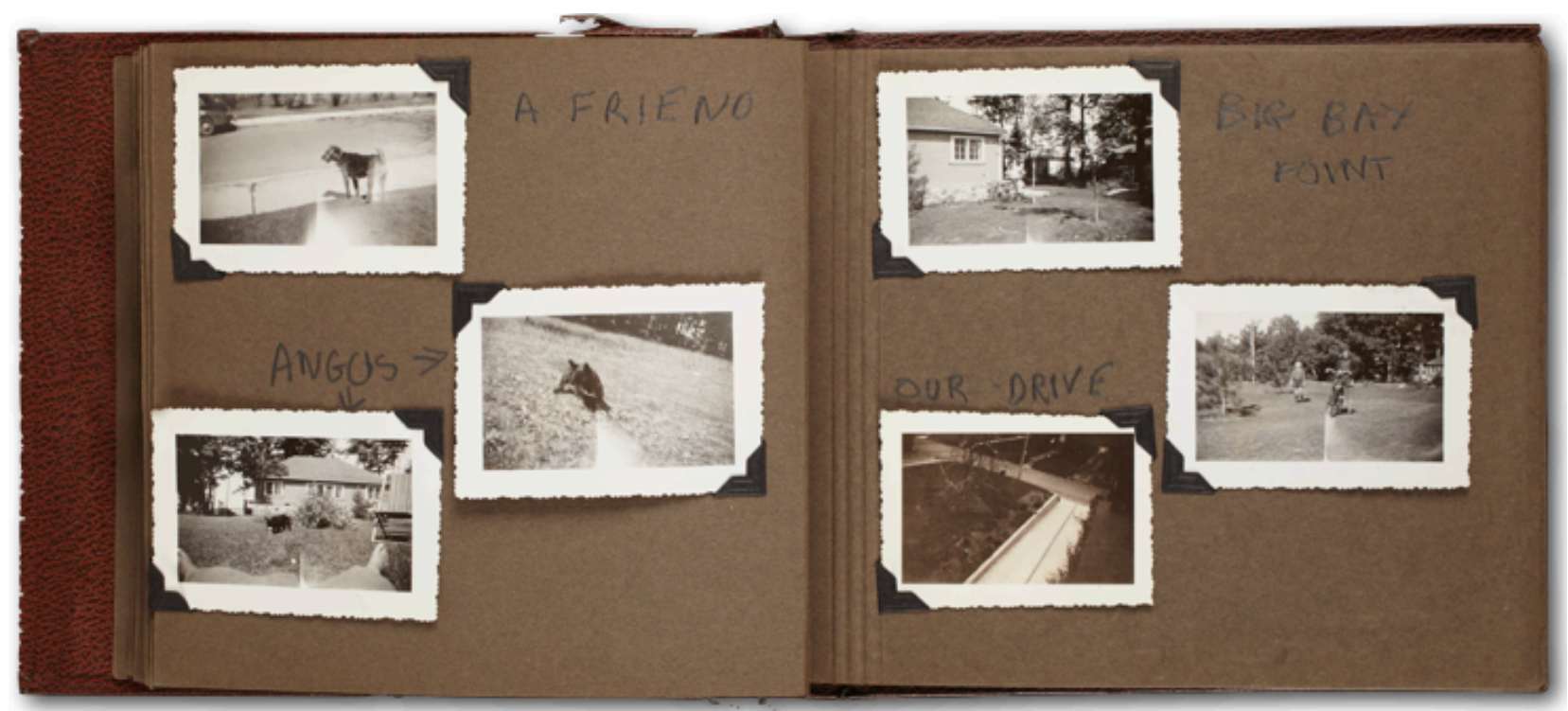

Fig. 3. Alan's childhood album, 1930s

\footnotetext{
${ }^{41}$ Tam Fairlie, interview by the author, May 22, 2015.

${ }^{42}$ The size of photographic prints produced by Kodak cameras is discussed in The Art of the American Snapshot. According to Diane Waggoner, the No. 2 Kodak Brownie made rectangular negatives that were approximately $2 \frac{1 / 4}{4} 3^{1 / 4}$ inches in size.
} 


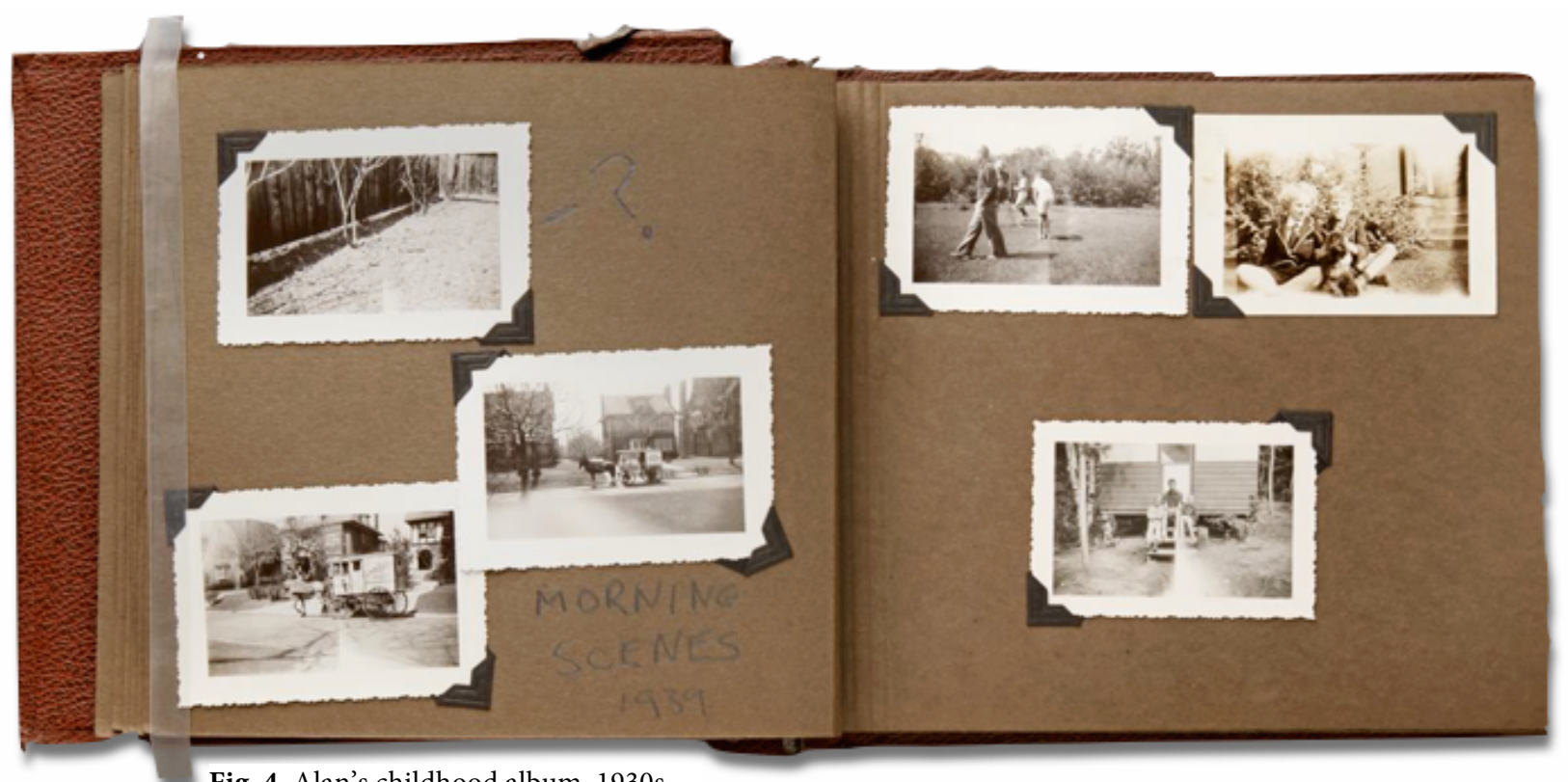

Fig. 4. Alan's childhood album, 1930s

Although Alan did not compile all twelve albums himself, it is obvious that he made a continuous effort to build a collection that successfully documented his family's history. The Fairlies photographic practice can be better understood by examining each of the albums to determine what this particular family believed to be worthy of recording and preserving. As a collection, the Fairlie albums manifest a number of different interests. The first and most prominent one is purely photographic. Each album provides evidence that the compiler was interested in experimenting with photography and documenting various aspects of everyday life with a camera-family and friends, places visited, good times, accomplishments, and milestones. A second theme present in a number of the albums is an interest in urban life: street views, cultural events taking place at Union Station and on Bay Street in Toronto, special outings, and private school gatherings are commonly seen images. The third and final theme present in the Fairlie albums is a strong interest in and relationship to nature and the outdoors. The majority of the albums include photographs that were taken on camping trips depicting family members engaging in activities such as boating, horseback riding, swimming, golfing, and relaxing at various cottage sites throughout Northern Ontario. Alan's efforts to preserve his family's history have resulted in a rich collection of vernacular albums that not only represent his own personal interests and dreams, but that also assist in understanding 
what the entire Fairlie family viewed as important and significant-the factors that contributed to shaping their identities.

\section{EARLY ALBUMS}

Louis J. Fitzpatrick (1879-1943) - Anne Louise Fairlie's older brother and Alan’s uncle-compiled the two earliest albums in the collection in the late nineteenth and early twentieth century (AGO.102891 and AGO.102898). In terms of their materiality, the photographs in these two albums do not appear to have been commercially produced, suggesting that a family member took, developed, and printed the photographs. The silver gelatin prints in each of the albums are not standardized in size or appearancethey do not contain white borders or have a glossy finish, the exposures are inconsistent, and the majority of the images are suffering from varying degrees of silver mirroring.$^{43}$ As examples of early snapshots, these albums represent a time in the history of photography before the medium became an industrialized operation (fig. 5). In this sense, Louis J. Fitzpatrick was a skilled amateur who not only had a strong interest in photography, but who was also knowledgeable about camera technology, exposure times, and darkroom techniques. The photographs in these albums document a trip taken to the United Kingdom in the early

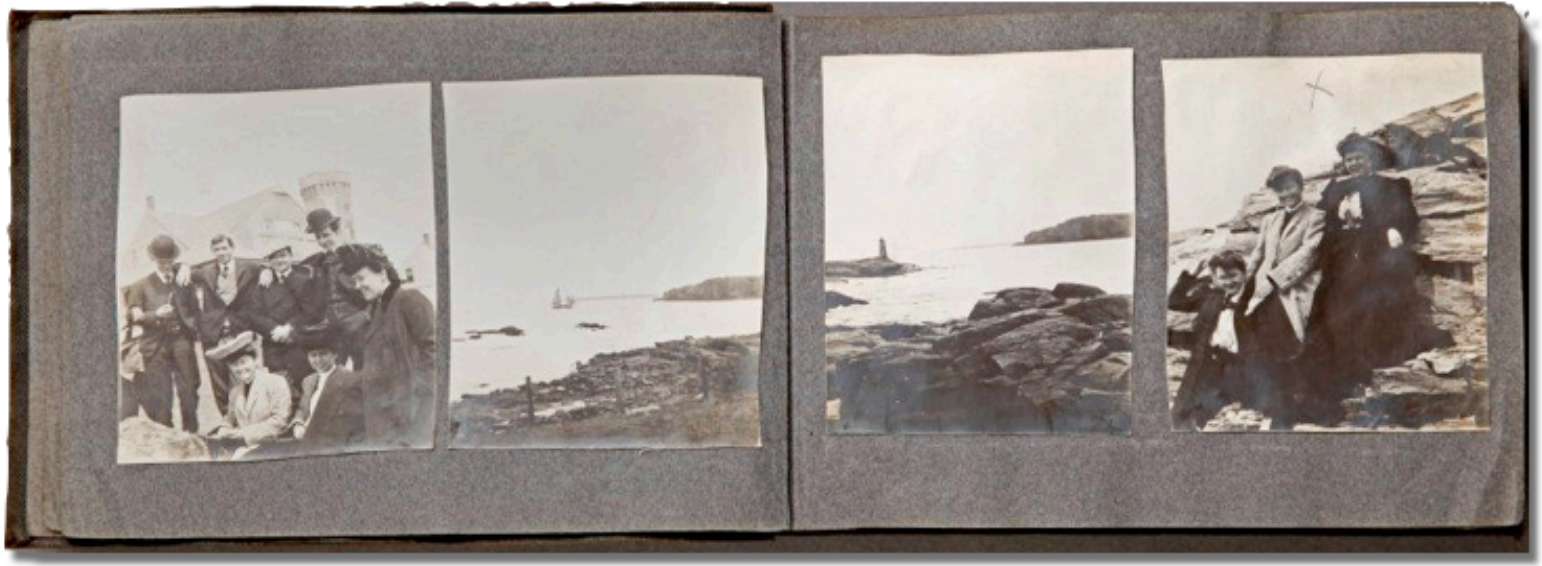

Fig. 5. Early snapshots taken in the UK, c. 1905

\footnotetext{
${ }^{43}$ AGO.102891 measures approximately $32.2 \times 25.5 \times 34 \mathrm{~cm}$ in size and contains 237 photographs. AGO.102898 measures approximately $18.6 \times 28 \times 2.5 \mathrm{~cm}$ in size and contains 207 photographs. According to the Getty Conservation Institute, silver mirroring is characterized by a bluish or shiny discoloration in the shadow areas of a photographic image caused by oxidation of the elemental silver, creating a mirror-like appearance.
} 
1900s and images of family members on a large ship, presumably while travelling in Europe. The albums also include various candid snapshots taken in Ottawa of members of the Fitzpatrick family dressed in very fashionable attire - three-piece suits, bowler hats, tailored jackets, and frilled blouses. The cost of early Kodak cameras was expensive for people of middle-class income, but as part of the upper-class elite, the Fitzpatricks were able to practice photography before it became affordable and widely accessible.

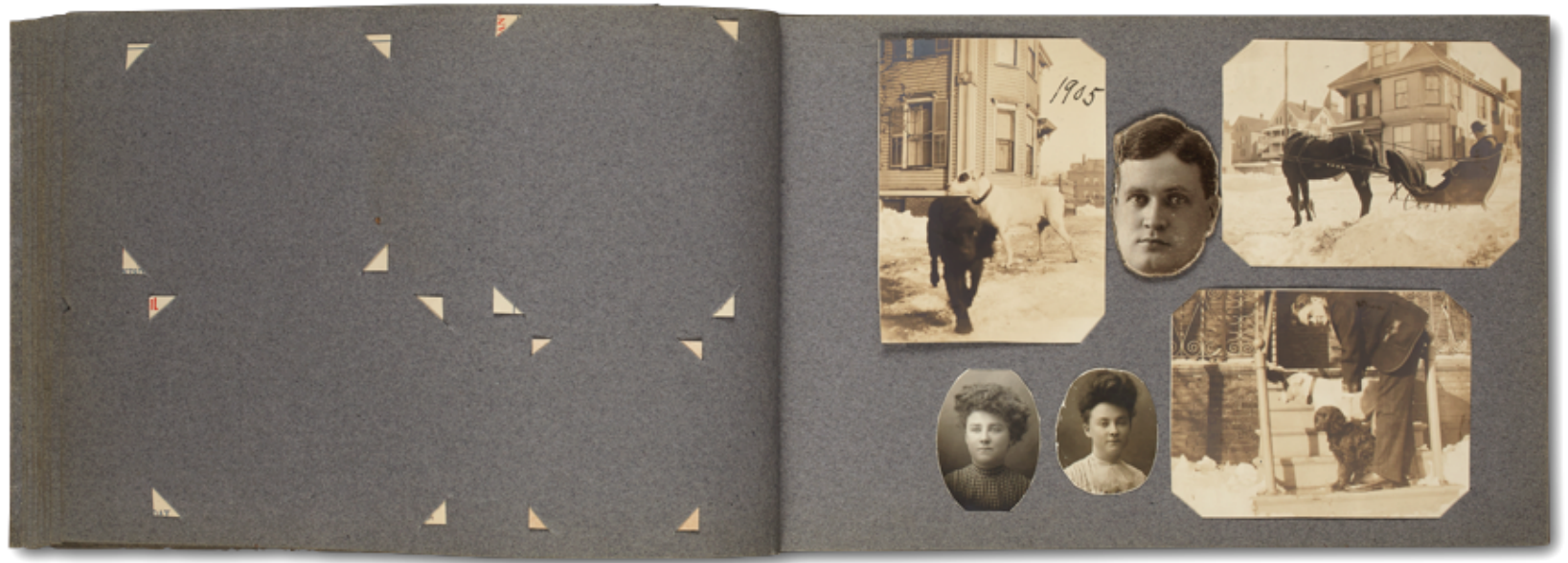

Fig. 6. Early experiments in photography, c. 1905

In the early days of photography, the primary type of image was a carefully staged studio photograph. These photographs, usually in the form of a carte-de-visite or cabinet card, were considered to be cherished family possessions. One of the earliest albums contains an interesting example of the inclusion of formal studio portraiture in an unconventional sense (AGO.102898). On one page in particular, family members and friends have been cut out of their original composition and only their heads have been included on the album page (fig. 6). The cut-out studio images are intermingled with more candid snapshots of family members and pets. What is intriguing here is not necessarily the subject matter of these images, but what was done with the photographs after they were taken. In this example, the albummaker's "imaginative voice" presents images that are uniquely arranged and unusually cropped. ${ }^{44}$ While photograph albums from the period often included slots that fit standard-size, commercially produced images, the Fitzpatricks chose to personalize their albums by uniquely arranging the images within. As

\footnotetext{
${ }^{44}$ Levine and Snyder, Snapshot Chronicles, 19.
} 
Geoffrey Batchen has pointed out in his many writings on the subject, family albums provided everyday people with the opportunity to represent their autobiographies in "artful combinations of words and pictures" and allowed them to visually express the importance of their social rituals, personal dreams, and memories. $^{45}$

\section{MINING ALBUMS}

Canada was experiencing rapid social and economic change as it entered the twentieth century at the height of the Second Industrial Revolution. ${ }^{46}$ At the time, Northern Ontario was the center of the mining industry in Canada, producing enormous economic and industrial wealth for the country. The Timiskaming and Northern Ontario Railway construction began in 1902 and lead to the important discovery of silver in Cobalt. ${ }^{47}$ According to a number of historians, Cobalt was considered to be one of the most accessible and successful mining camps in Canada. ${ }^{48}$

After graduating from Queen's University in Kingston in 1902, Matthew Fairlie and his wife Anne Louise moved to Cobalt where he worked as a Mining Engineer for Kerr-Addison Gold Mines Ltd. during the Silver Rush of 1903. Reflecting his interests and dedication to the Ontario mining frontier, Matthew

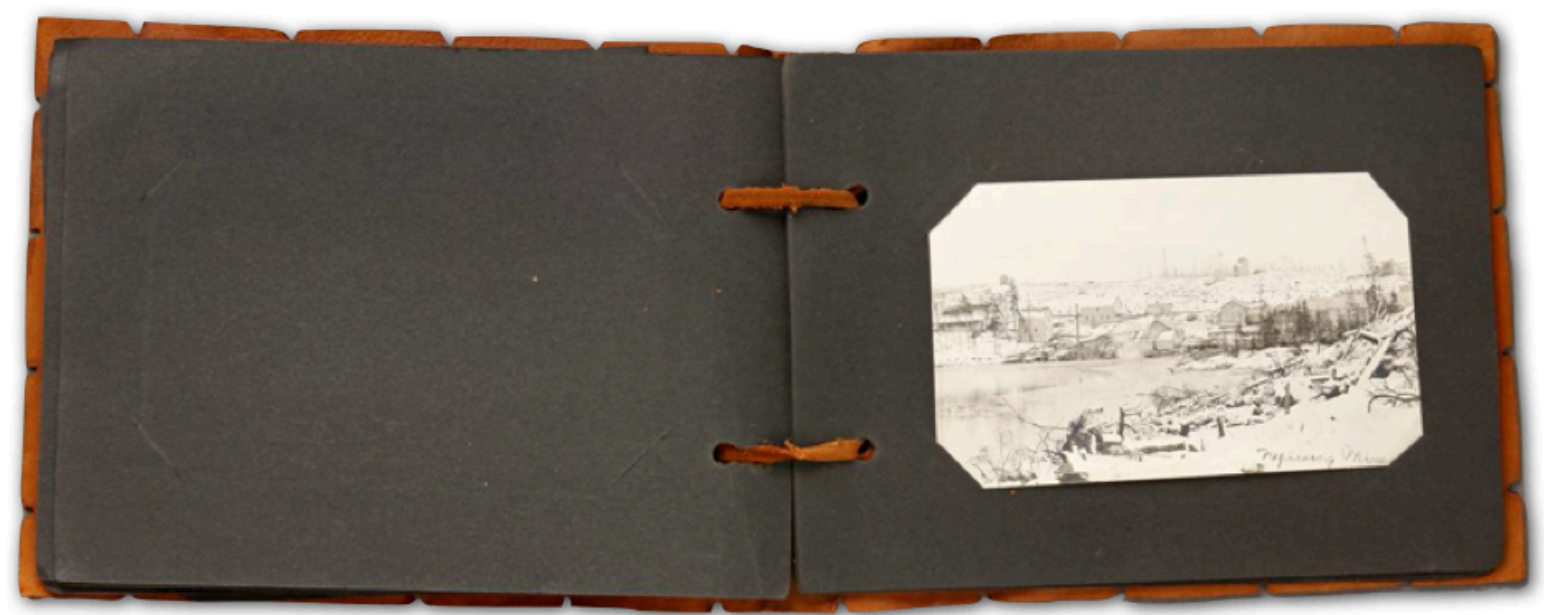

Fig. 7. Picturesque Silverland, 1922

\footnotetext{
${ }^{45}$ Geoffrey Batchen, Forget Me Not: Photography and Remembrance (Cambridge: MIT Press, 2006), 57.

46 The McCord Museum, "Digging for Treasure: Mining in Canada," accessed May 5, 2015.

${ }^{47}$ John Sandlos and Arn Keeling, “Mining," The Canadian Encyclopedia, accessed on May 5, 2015.

${ }^{48}$ H.V. Nelles, The Politics of Development: Forests, Mines, and Hydroelectric Power in Ontario, 1849-1941 (Kingston: McGillQueen's University Press, 2005). Judith Hansen O'Toole, Different Views in Hudson River School Painting (New York: Columbia University Press, 2008).
} 
Fairlie collected and compiled a number of albums recording his experiences in Cobalt. One album from 1922 is titled "Picturesque Silverland," a simple declaration of the subject matter within (AGO.102887).

The title suggests an interesting juxtaposition of the industrialized world versus the picturesque. The picturesque aesthetic has long been associated with literary and artistic works. ${ }^{49}$ The concept alludes to a particular way of seeing and portraying nature as an idealized composition that is suitable for a painting. The album documents various mining sites and landscapes in Cobalt and surrounding towns such as Haileybury and New Liskeard (fig. 7). Although towns such as these were recognized mostly for their contributions to the mining industry, the photographs in this album taken by Matthew Fairlie focus on a different approach, drawing attention to images that highlight a more beautiful and scenic view of "Silverland." The album, which contains 22 carefully placed silver gelatin photographs, also reflects the personal interests of Matthew Fairlie and the dedication he had for his profession. Each photograph is carefully composed and laid out, suggesting that this album was particularly significant.

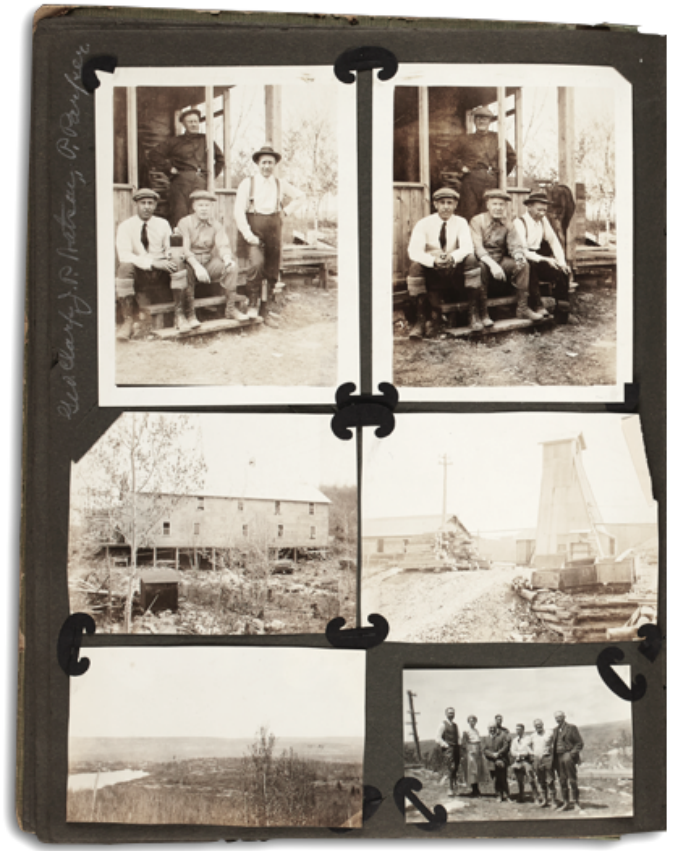

Fig. 8. Mining scenes and equipment, c. 1903-1915

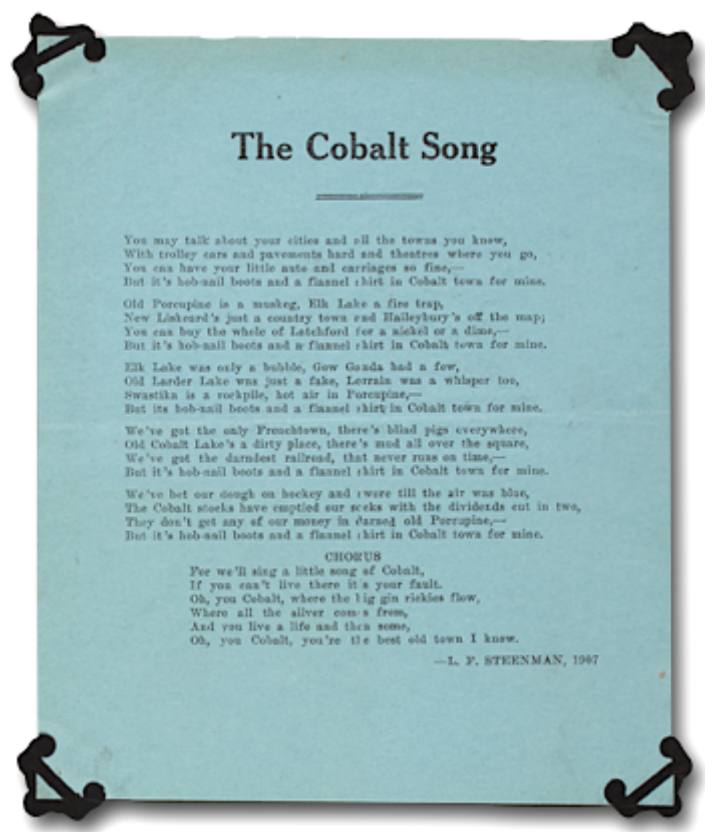

Fig. 9. The Cobalt Song, c. 1910

\footnotetext{
${ }^{49}$ This book was published in association with the Westmoreland Museum of American Art. The concept of the picturesque was derived from the Italian word pittoresco, "from a picture," and defines an object or view worthy of being included in a picture. The picturesque was formulated into an aesthetic category in late eighteenth century Britain, where it was primarily applied to the practices of landscape painting.
} 
Another album from the early twentieth century (AGO.102896), which primarily contains traditional family photographs and snapshots, has also been used to preserve images of mining scenes and equipment, as well as photographs taken at the Cobalt Production Company in the 1920s (fig. 8). "The Cobalt Song," elegantly typed on decorative blue paper, has been secured on the inside back cover of the album with black photo-corners (fig. 9). Like many other mining camps of the time, Cobalt had its own

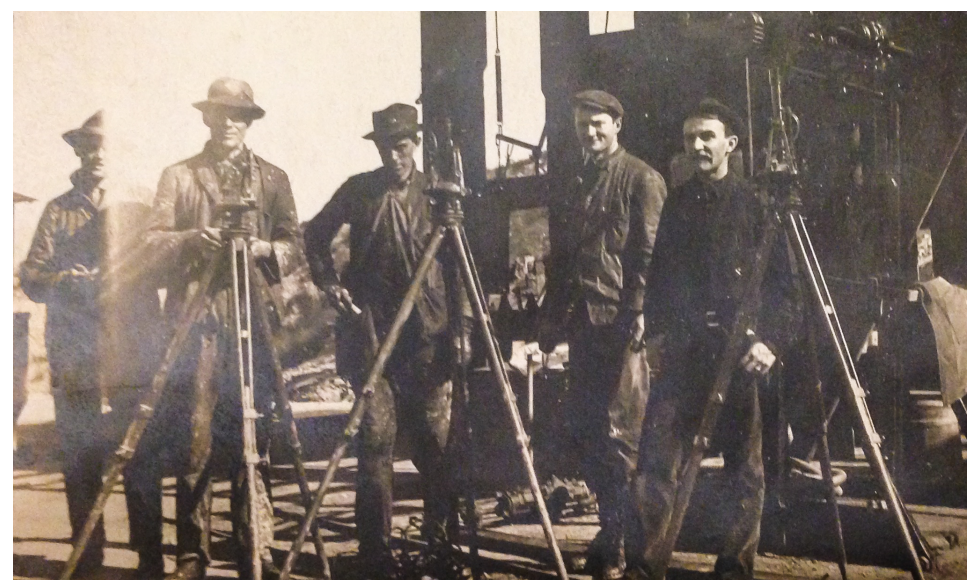

Fig. 10. Miners with their cameras, Cobalt, Ontario, c. 1910 song that helped to keep the memories of the town's mining heritage alive.$^{50}$ Matthew Fairlie and the members of his mining crew were eager to photograph their experiences in and around the town in order to record and preserve their mining legacy (fig. 10).

The mines in Cobalt began to close in the 1920s, which is consistent with when the Fairlie family decided to relocate to Toronto. ${ }^{51}$ As business expanded in the city, many people were drawn there for daily employment. Furthermore, because life on the mining camps was considered to be "raw and rough," Matthew Fairlie most likely accepted a job as a mining consultant in the city where he could begin to raise a family. This pivotal point in Canadian history also corresponded with the rapid growth in technological innovations that were changing the character of Canadian life - "the harnessing of electricity, the invention of the telephone and telegraph, and eventually the introduction of the automobile in the early twentieth century." ${ }^{52}$ As Diane Waggoner states in The Art of the American Snapshot, each of these leaps forward accelerated the pace of life. Responding to such dramatic developments, Canadians "embraced the idea of

\footnotetext{
${ }^{50}$ Charles Dumaresq, “The Cobalt Song," Cobalt Mining Legacy, accessed May 12, 2015, http://www.cobaltmininglegacy.ca/cobaltSong.php

${ }^{51}$ Charlie Angus and Brit Griffin, We Lived a Life and Then Some: The Life, Death, and Life of a Mining Town (Toronto: Between the Lines Publishing, 1996), 58.

${ }^{52}$ Sarah Greenough et al., The Art of the American Snapshot, 10.
} 
family and domesticity as the greatest source of personal happiness..." ${ }^{53}$ Moreover, as consumer society continued to develop, so did the pursuit of leisure activities and interests in recreation and travel. The photographs in the Fairlie albums represent the family's reaction to the urban growth that was taking place in the early twentieth century. Matthew Fairlie and his family were able to escape their busy city lives in Toronto as they pleased, retreating to various sites and towns throughout Northern Ontario.

\section{SOCIAL CLASS}

The first few pages of a 1929 album (AGO.102897) include images of the Fairlie family's home in Cobalt - the parlor and the library, as well as various exterior shots of the house and yard (fig. 11). Other albums (AGO.102896 and AGO.102890) also contain images of the Fairlie's home on Shorncliffe Avenue in Forest Hill, one of Toronto's wealthiest neighborhoods. By examining the photographs within each of the albums, conclusions can be drawn about the social and economic class of the Fairlie family.

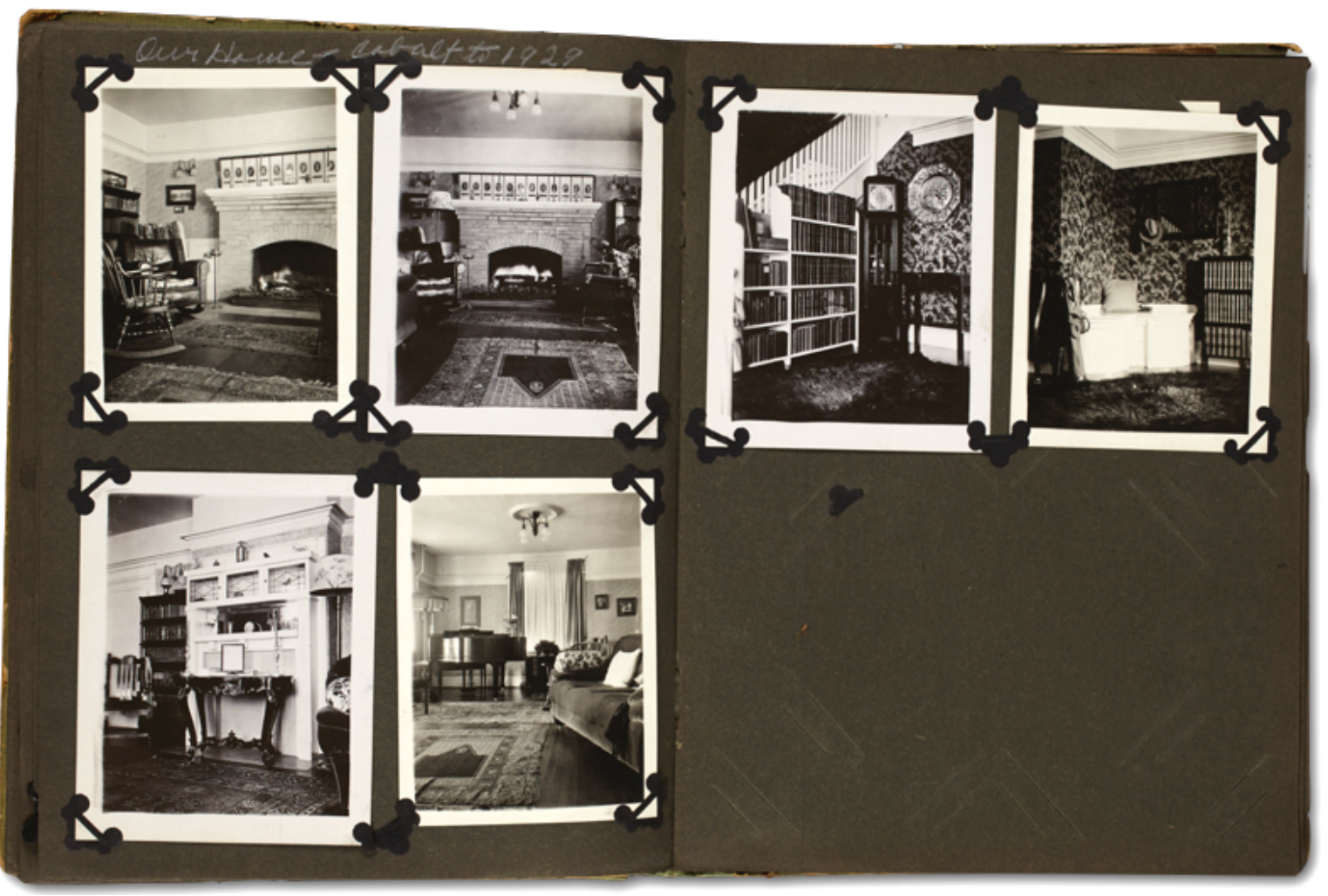

Fig. 11. Interior shots of the Fairlie's home in Cobalt, Ontario, 1929

\footnotetext{
${ }^{53}$ Ibid.,10-11.
} 
In figure 12, Matthew Fairlie has been photographed sitting in the front seat of a brand new Buick.

Another album contains photographs of Alan and Joyce posing in front of the fireplace on a bearskin rug

(fig. 13). ${ }^{54}$ As part of upper-middle-class society, the Fairlies could afford valuable belongings and

expensive home furnishings. From the 1930s to the 1950s, the

family home and the possession of consumer items such as cars

became established as common photographic subject matter. ${ }^{55}$

There are many examples of family members and friends posing

beside the family car, or the positioning of the house as a

backdrop to family photos taken during special outings or

holiday gatherings. In this sense, the family album was used as a

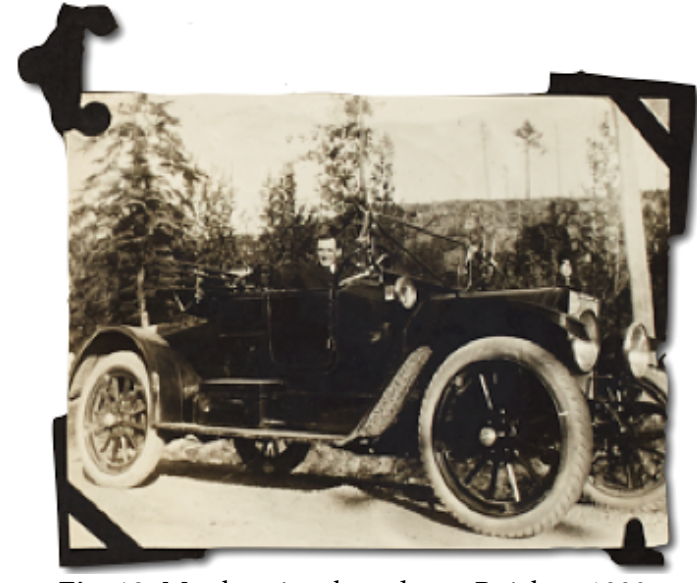

Fig. 12. Matthew in a brand new Buick, c. 1930

way of acknowledging and drawing attention to certain prized possessions. These albums were created

during a time period that suffered through the Great Depression and the Second World War, but the

Fairlie family's picturing taking did not diminish, nor did their ability to acquire new things and travel

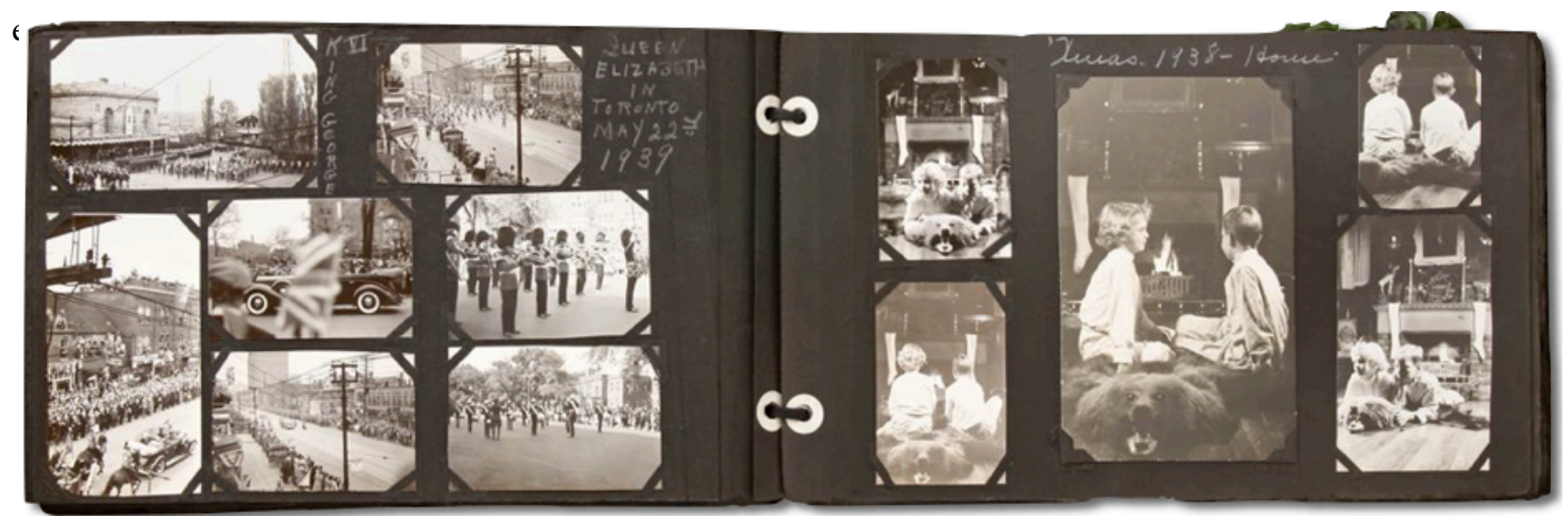

Fig. 13. Alan and Joyce at Christmas, 1938

\footnotetext{
${ }^{54}$ The archival collection includes a document outlining the inventory and valuation of the personal estate of Matthew F. Fairlie conducted after his death in 1944. The appraisal includes some of the following assets and what their value would be in Canadian dollars today: a floral Caucasian room rug (approximately \$4,000), a 132-piece Coalport porcelain dinner set manufactured in England (approximately \$5,500), and a Westington radio with a walnut console (approximately $\$ 1,500$ ). According to an article published in the Toronto Star, when Anne Louise Fairlie died in 1961 she appointed Alan as the main beneficiary of her estate, which at the time was worth $\$ 89,150$; the equivalent to over $\$ 700,000$ today.

${ }^{55}$ Deborah Chambers, "Family as Place: Family Photograph Albums and the Domestication of Public and Private Space" in Picturing Place: Photography and the Geographical Imagination, eds. Joan M. Schwartz and James R. Ryan (New York: I.B. Tauris Co Ltd, 2003), 111.
} 
Another prominent feature found in the Fairlie albums is the relationship that both children had to private schools and summer camps. Both Alan and Joyce attended private schools in Toronto and organized summer camps throughout their childhood. One album in particular (AGO.102890) contains a number of photographs taken with a No. 2 Kodak Brownie camera of Alan and Joyce posing in their school uniforms (fig. 14).

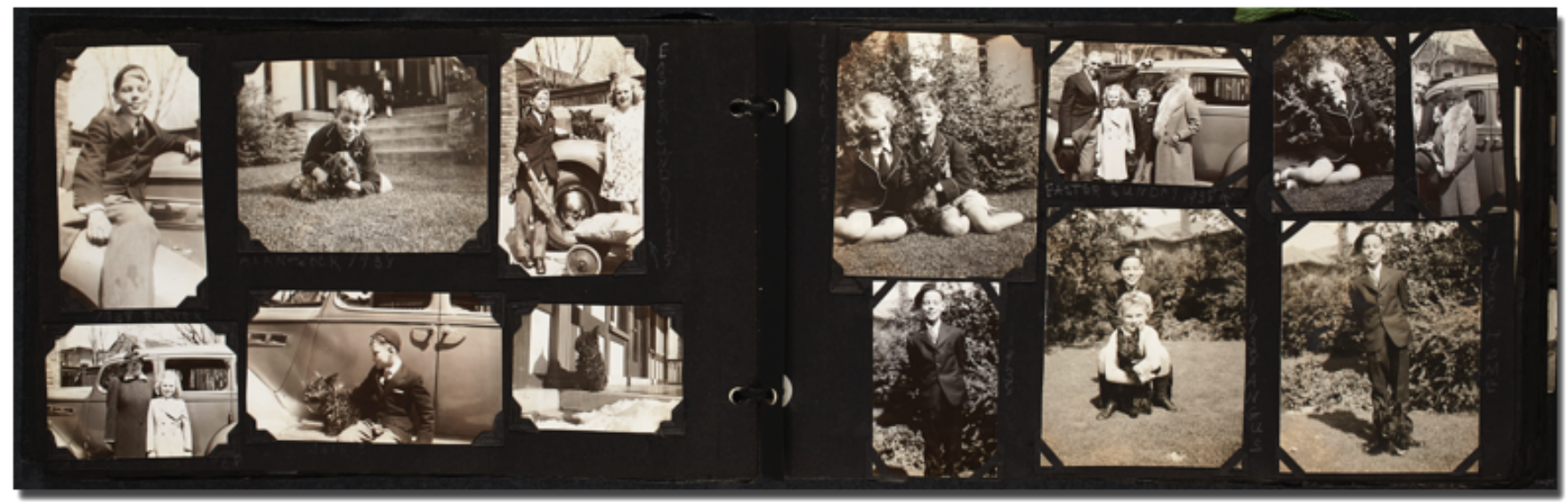

Fig. 14. Alan and Joyce in their school uniforms, 1939

Alan attended Crescent School and Upper Canada College-both all-boys private schools in Toronto-and Joyce went to Bishop Strachan School for girls. The cost of private schools in Toronto during this time was the equivalent to approximately $\$ 30,000$ today, suggesting that these types of schools were targeted at an upper-class elite. Elite culture in Ontario was linked to private schools, as well as summer camps, that offered an environment of select contacts for those of privileged backgrounds. ${ }^{56}$ According to historian Sharon Wall, summer camps emerged "as a reaction to urban, industrial culture and represented yet another manifestation of bourgeois longing for authentic experience and nostalgia for simpler times. ${ }^{\prime 57}$ Private, for-profit camps, often located in the desirable Muskoka, Algonquin, and

\footnotetext{
${ }^{56}$ Sharon Wall, The Nurture of Nature: Childhood, Antimodernism, and Ontario Summer Camps, 1920-55 (Vancouver: UBC Press, 2009), 66.

${ }^{57}$ Ibid., Xv.
} 
Temagami regions of Ontario formed the elite of the province's camping community and catered to a wellto-do middle- and upper-class clientele. ${ }^{58}$ Four albums in the Fairlie collection (AGO.102891, AGO.102892, AGO.102893, and AGO.102894) are souvenir albums from Alan's summer experiences at Camp Temagami that were produced between the years of 1939 and 1946 (fig. 14). These albums are different from the others, as they were commercially produced and given to campers as a keepsake and memory of their summer camp experiences. Each album measures $3 \times 6$ inches and contains approximately 16 silver gelatin photographs that have been bound with colourful string. Each has a cover page that has been stamped with "Camp Temagami" and the date it was produced. Although the Fairlie family did not personally compile these albums, their function as collectible souvenirs speaks to Alan's childhood passion for camping as a retreat from the modern world. The images in each of the albums consistently depict a sense of pride among campers as they learnt new skills—such as fishing and canoeing-and adapted to the wilderness environment.

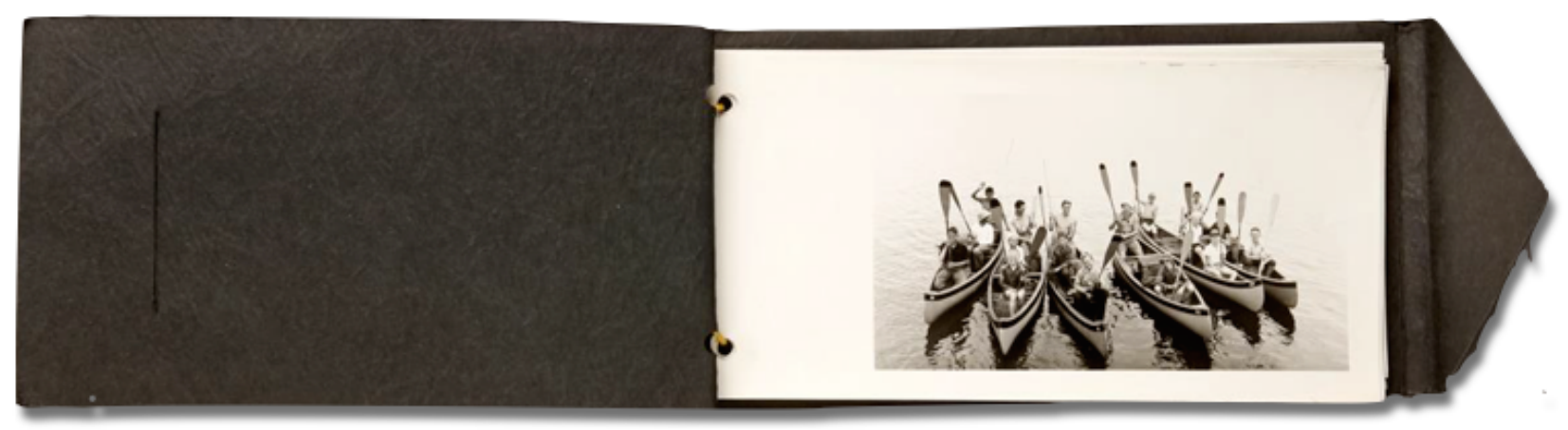

Fig. 15. Alan’s Camp Temagami album, 1936

\section{NATURE \& THE OUTDOORS}

The albums in the Fairlie collection testify to the newfound importance of recreation and leisure as the aspects most worthy of recording during the transition into modern life. The albums created in the 1920s and later include an abundance of images depicting outdoor activities and vacation destinations, a common theme found in snapshot photography from the time. According to historian Cynthia Comacchio, Canadians were increasingly interested in leisure during this time because of drastic changes

\footnotetext{
${ }^{58}$ Ibid., 44, 20.
} 
taking place- "urbanization, technology, and the ease of transportation [all] allowed more opportunities for fun." ${ }^{59}$ Photography was, and still is, a vehicle through which people expressed themselves and ideas of belonging at a time when the world was changing drastically. ${ }^{60}$

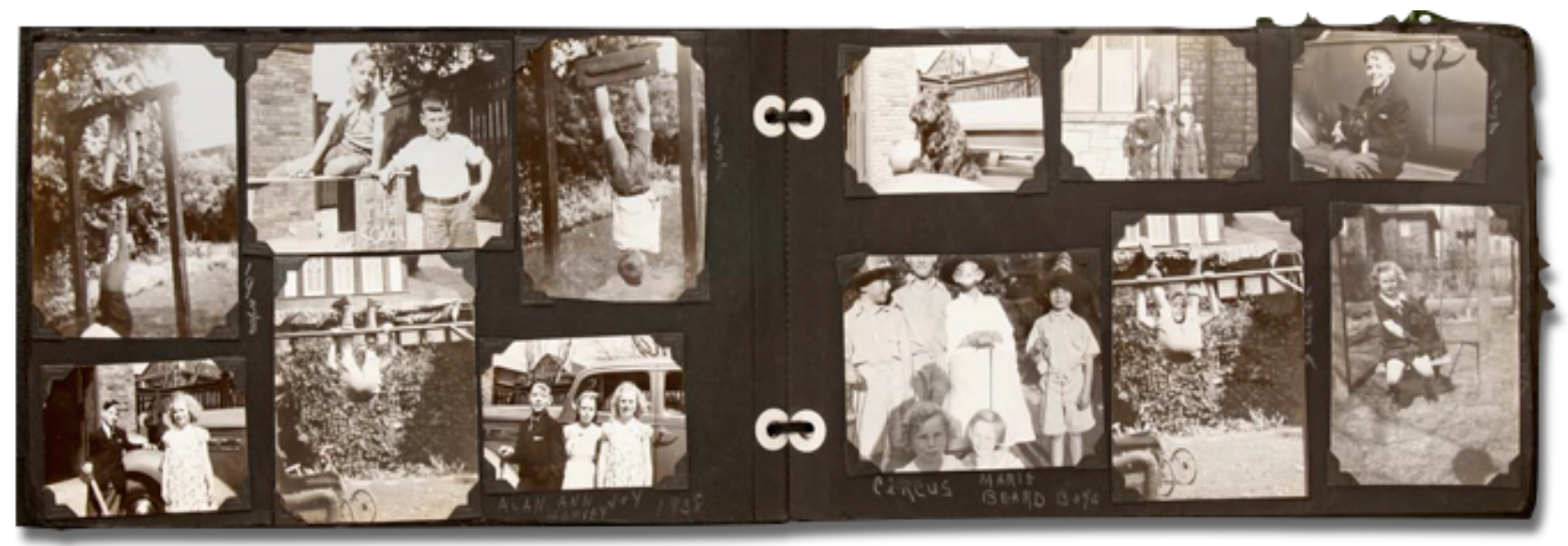

Fig. 16. Alan and Joyce in Toronto, 1938

Almost all the albums in the collection contain photographs depicting travel destinations throughout Ontario where the Fairlie family spent a significant amount of time away from the city. According to handwritten captions, the Fairlies took camping trips to Niagara, Big Bay Point, Lake Simcoe, Temagami, Rostrevor, and Elgin.

Taken together, these albums can be

linked to both nature and the urban

industrial world, documenting

excursions in the wilderness and life

in upper-middle-class Toronto

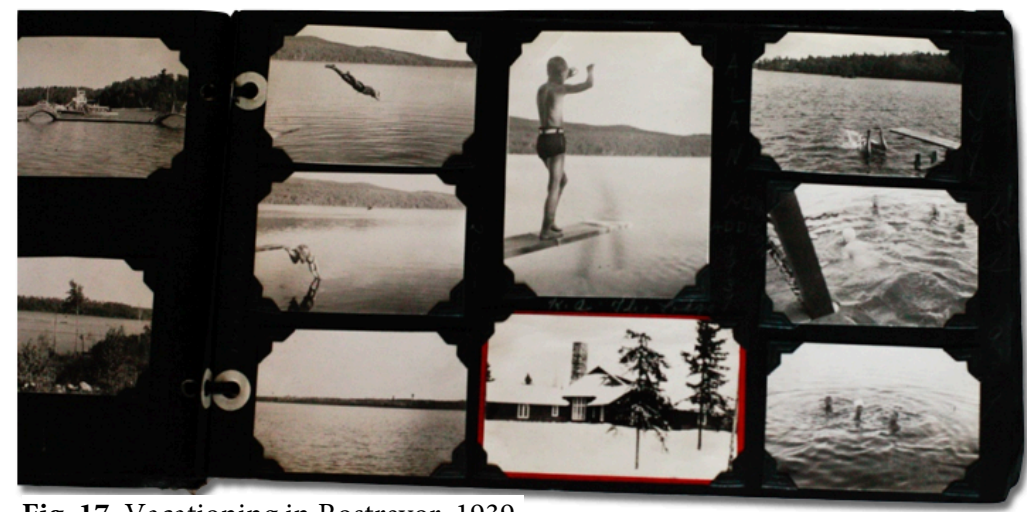

Fig. 17. Vacationing in Rostrevor, 1939

during the first half of the twentieth century. On one hand, they reflect an anti-modern perspective and, on the other, a fascination with all things modern, especially photography. As towns and cities grew rapidly during the first half of the twentieth century, Canadians embraced nature as an antidote for urban industrial culture. An interesting example of this can be seen in an album compiled in 1937 (AGO.102896),

\footnotetext{
${ }^{59}$ Cynthia R Comacchio, The Dominion of Youth: Adolescence and the Making of a Modern Canada, 1920-1950 (Waterloo: Wilfred Laurier University Press, 2008), 163.

${ }^{60}$ Chambers, "Family as Place," 96.
} 
which chronicles the Fairlie family both at their home in Toronto, as well as during vacations and camping trips throughout Ontario (figs. 16-18). The album is an interesting mix of formal family snapshots and collaged images of family members partaking in activities such as horseback riding and canoeing. These photographs portray the Fairlie family happily immersed in the environment, excited about nature and enjoying the outdoors.

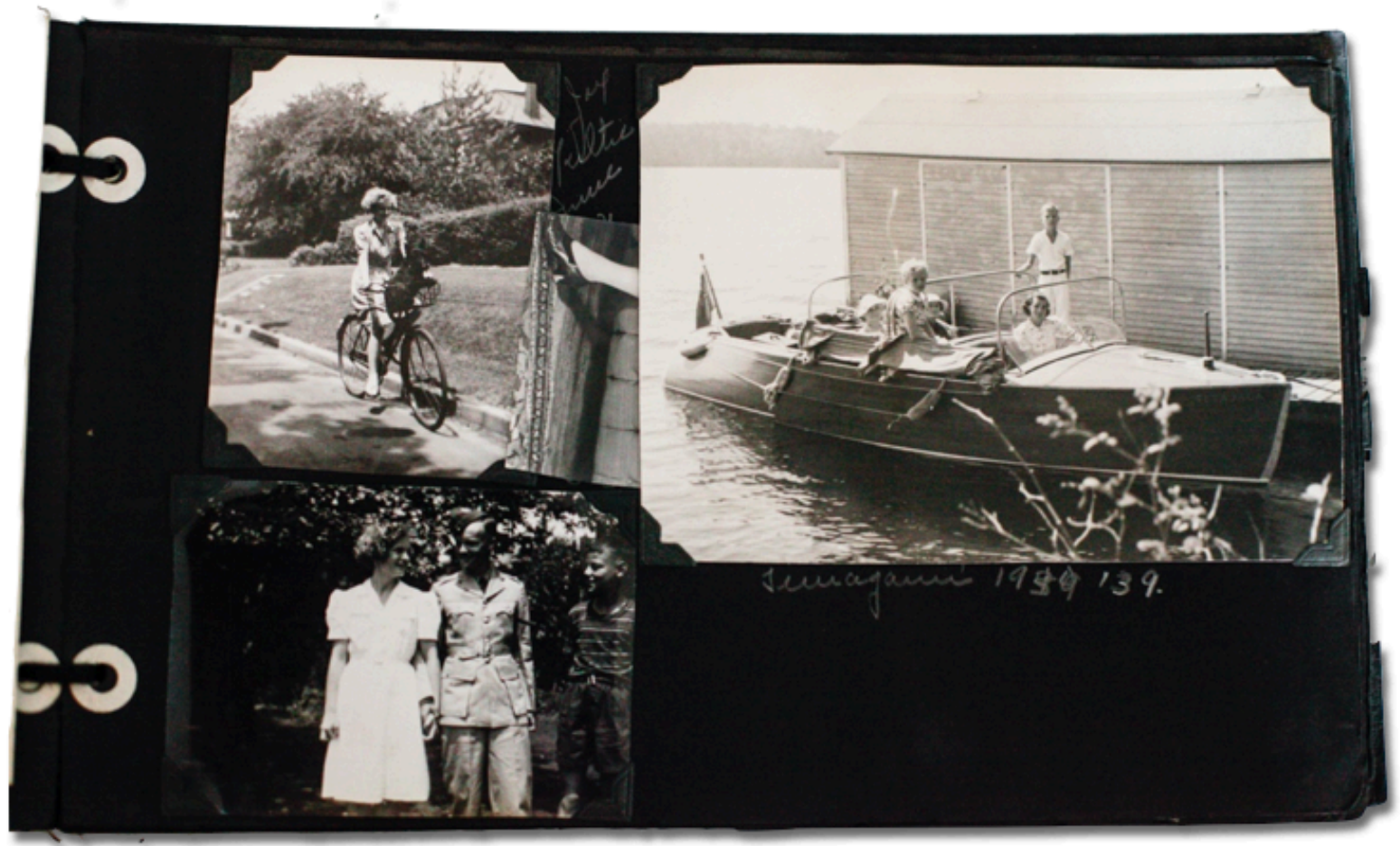

Fig. 18. Vacationing in Temagami, 1939

The sequences of images heighten the contrast between the Fairlies' life in the city and their experiences in nature. One page from AGO.102896 contains photographs that are closely cropped and nestled near one another, evoking feelings of intimacy and personal significance. Each silver gelatin photograph on this page has been cropped to a small size-roughly $1 \times 2$ inches_and strategically laid out to form a cohesive narrative depicting one camping trip taken by Matthew Fairlie in the 1930s (fig. 19). It is interesting to note that the pages of this album in particular include pre-cut slots for standard-size photographs; however, Matthew did not utilize the predetermined layouts, but rather dictated where he wanted the photographs to 
be placed. Examining how he chose to sequence the images on the album page provides clues into the story he was trying to tell. Although the album is not arranged in chronological order, the images position the Fairlie family symbolically within the landscape and record a time of transition between urban living and wilderness.

This study examines the many narratives that arise out of family albums and assists in drawing attention to the ways in which photographs visually represent the trajectory of changing social and cultural values over time. As historical documents, the Fairlie albums are successful at providing a perspective that is emblematic of a larger social narrative-one that is rooted in ideas of Canadian identity. Canadian historian Douglas Cole states that the "shared discovery of the northern wilderness... [has always been] considered a symbol

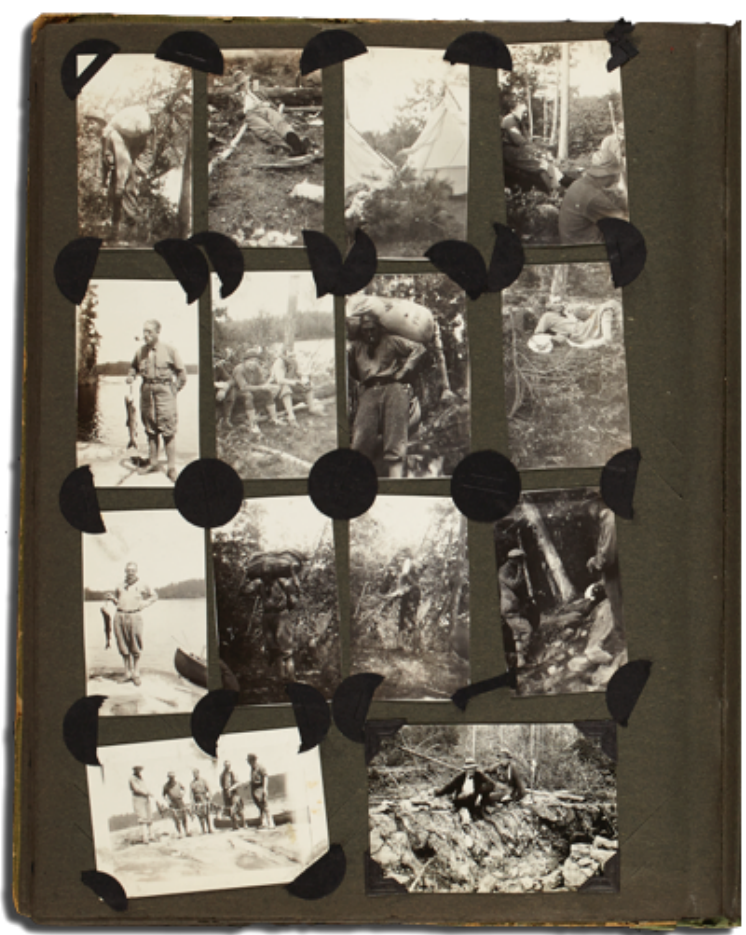

Fig. 19. Matthew's camping trip, 1930s of Canadian life." ${ }^{\prime 1}$ The development of wilderness parks, summer camps, and cottage movements began in the 1890 s with the growth of industrial cities and the simultaneous development of a way to escape them. ${ }^{62}$ As a result, Canadians quickly developed an appreciation for the natural environment. ${ }^{63}$ Interest in the physical environment of the Canadian landscape gained popularity throughout the twentieth century and has grown to be one of the defining aspects of the country's identity today.

In the first half of the twentieth century, art in Canada was also focused on a wilderness painting movement. Images of the north, industrialization, and the landscape are recurring themes that can be found in art produced by members of the Group of Seven. Their paintings played a significant role in the

\footnotetext{
${ }^{61}$ O'Brien and White, Beyond Wilderness, 129.

${ }^{62}$ Ibid., 129

${ }^{63}$ Ibid., 130
} 
nationalization of nature and contributed to the "wilderness ethos" that was developing in central Canada during the first half of the twentieth century ${ }^{64}$ Art, music, and literature from the time reinforced images of wilderness as representative of a truly Canadian experience. The introduction of the camera in the nineteenth century, combined with its continuing technological developments throughout the twentieth century, broadened the imaging capabilities for visually interpreting nature. ${ }^{65}$ The images contained within the Fairlie albums are representative of the growing obsession with Canada's landscape that was taking place during the first half of the twentieth century. The practice of photography was the connecting factor for the Fairlies to both their modern life in the city of Toronto and their experiences with nature.

Photography provided an opportunity for the Fairlie family to document both their life in the city as well as their time spent away from it.

\section{CONCLUSION}

Throughout his life, Alan Fairlie was always adventurous and loved the outdoors. He climbed the Matterhorn, worked the railroads, was a crewmember on a ship that sailed Lake Ontario, trekked through Nepal and South America, and was a member of the first team to journey into Panama. He even made it to Fairlie Castle in Ayrshire, Scotland ${ }^{66}$ Alan documented some of his travels in a scrapbook after returning home from a three-month-long cruise in 1950. This album is unique from the others in the collection, as it includes fewer photographs and is made up of mostly collaged materials (AGO.102886). Alan's travel diary, "The Personal Record of a Good Will Ambassador," is comprised of 78 bound pages with ribbon and serves as both a keepsake for his experiences abroad and a reference tool for the many places he visited. Scrapbooks can be compared to a movie or a photograph in that they all capture lived time in a material

\footnotetext{
${ }^{64}$ O’Brien and White, Beyond Wilderness, 3-6.

${ }^{65}$ Chris Finn, "Connections: Ansel Adams, Edward Burtynsky and the Group of Seven” (Kleinburg: McMichael Canadian Art Collection, 2013).

${ }^{66}$ Kelly Waters, "Alan Takes Scooter on That Final Ride," Salt Spring News, 2001.
} 
form. ${ }^{67}$ Much like the photographs he took, Alan's scrapbook represents a material manifestation of memory and identity, capturing his passion for adventure and his interest in exploring new places. In On Longing, Susan Stewart discusses the scrapbook as a type of souvenir that contains items that refer to a specific place and event, allowing a person to reconstruct its narrative and evoke memory. Organized chronologically, each page of the scrapbook includes images and paper ephemera related to the various cities and towns that Alan visited during his travels. Each page is comprised of interesting juxtapositions that incorporate collaged pamphlets and maps, boarding passes, and postcards with personalized drawings and hand-written captions (fig. 20).

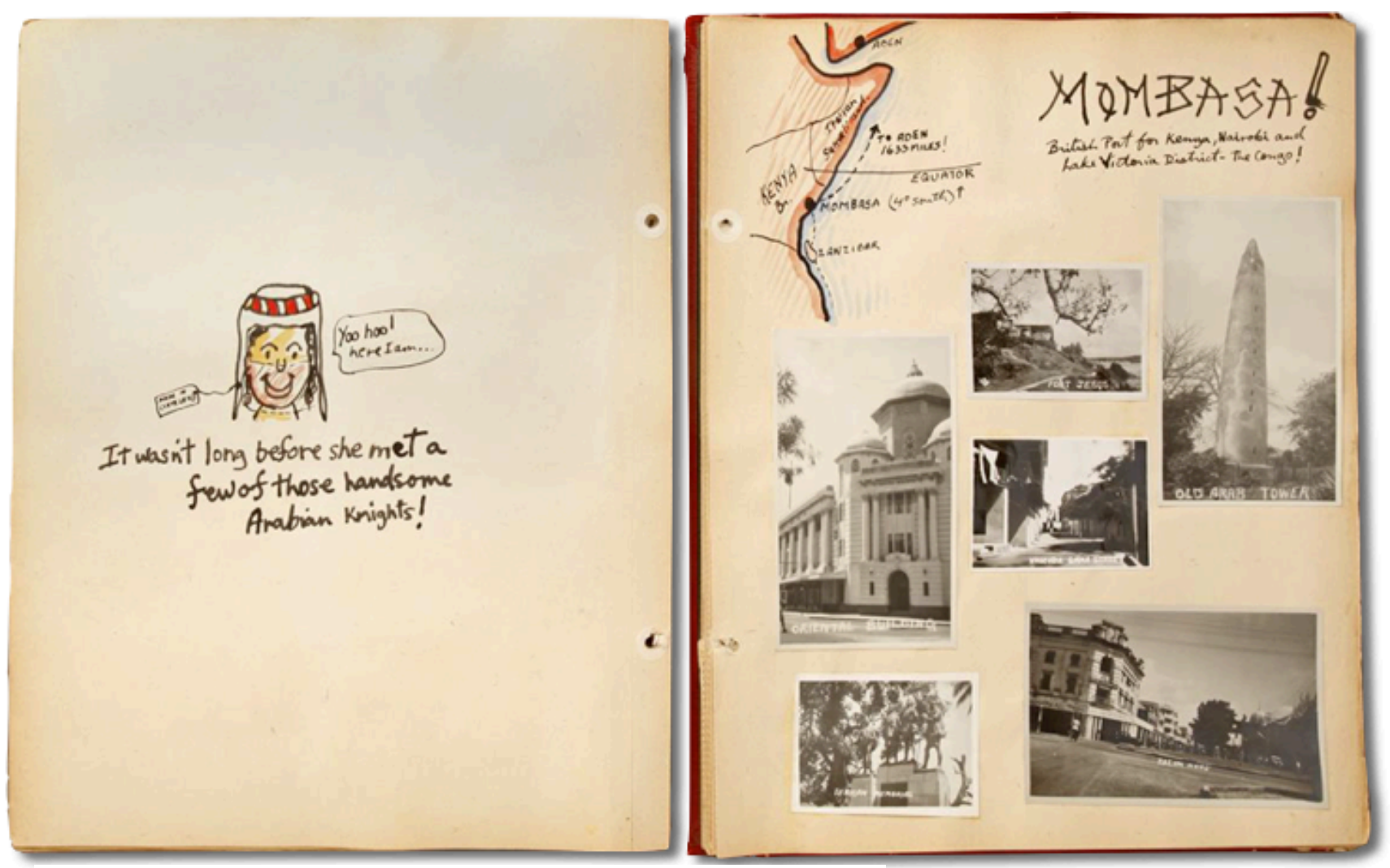

Fig. 20. Alan’s scrapbook, “The Personal Record of a Goodwill Ambassador,” 1950

Alan's passion for and interest in photography is also evident in certain photographs that suggest he experimented with different camera angles and lighting techniques. Throughout the 1930s, creating

\footnotetext{
${ }^{67}$ Katherine Ott, "An Introduction to the History of Scrapbooks," in Scrapbooks in American Life, eds. Katherine Ott, Susan Tucker, and Patricia Buckler (Philadelphia: Temple University Press, 2006), 3.
} 
silhouettes was a popular photographic exercise. The carefully staged nature of silhouettes conforms to earlier modes of theatrical performance for the camera. ${ }^{68}$ The inclusion of this type of photograph (fig. 21) indicates an artful passion for photography and an interest in the many possibilities of the camera. It comes as no surprise that Alan was experimenting with this type of imagery, as he would go on to become a successful filmmaker. In his twenties, he was commissioned to produce films for the Canadian Rugby team during Rugby Week in Bermuda; the real estate development at Giant's Tomb in Penetang, Ontario; and various programs for CTV Television Network. ${ }^{69}$ He also produced his own films documenting his travels around the world in which he explored archeological caves in Yucatan, travelled to Mexico, and shot footage in various countries throughout Europe (figures 22 and 23).

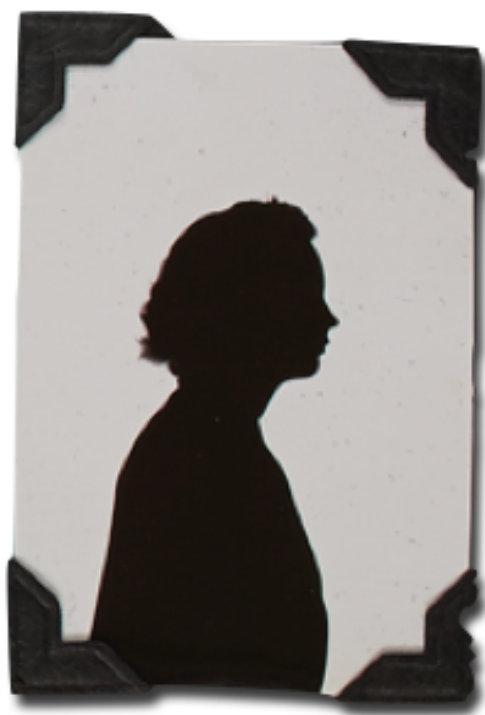

Fig. 21. Experimenting with silhouettes, c. 1930s

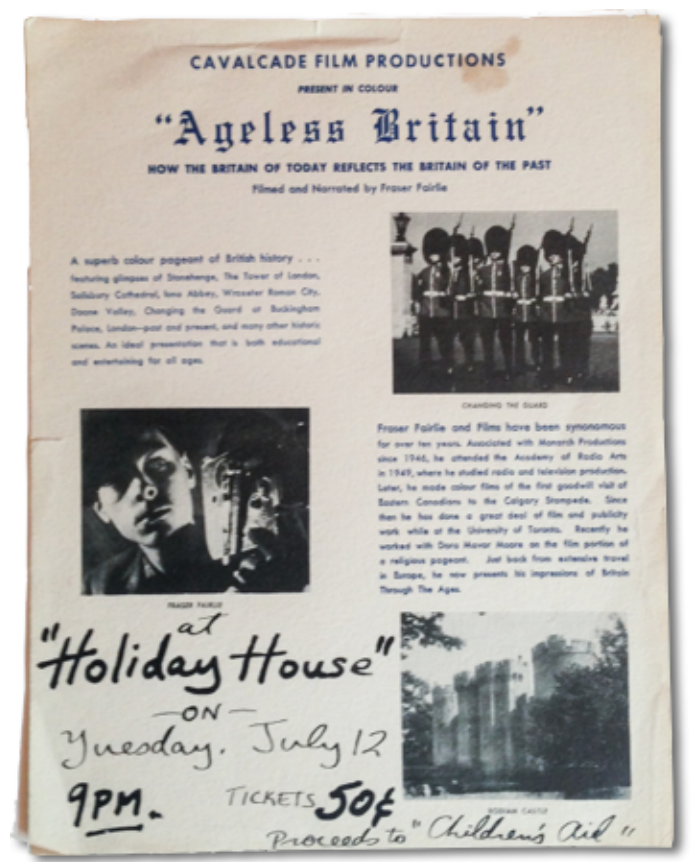

Fig. 22. Film poster for "Ageless Britain," filmed and narrated by Alan F. Fairlie, c. 1950

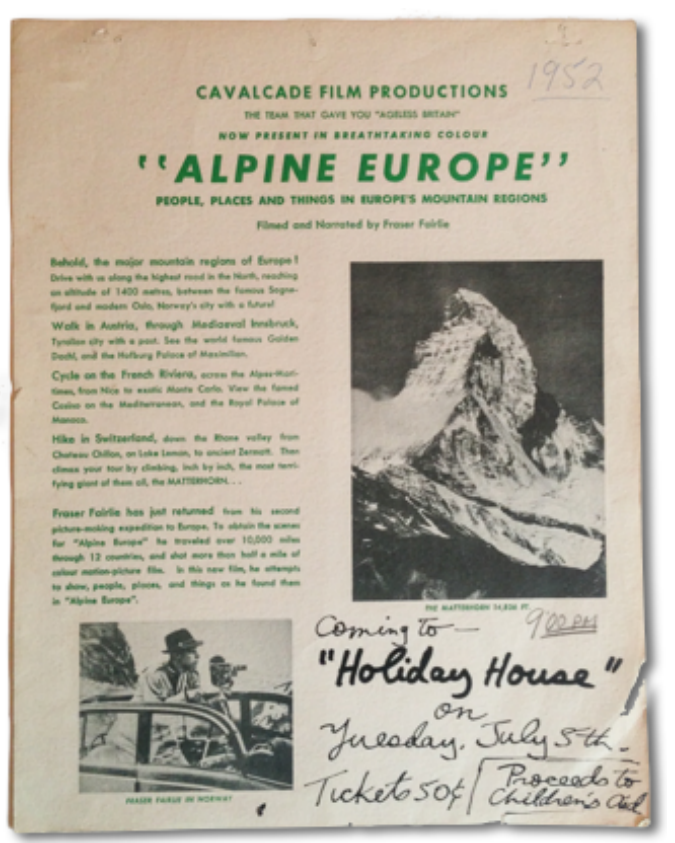

Fig. 23. Film poster for "Alpine Europe," filmed and narrated by Alan F. Fairlie, 1952

\footnotetext{
${ }^{68}$ Greenough et al., The Art of the American Snapshot, 89.

${ }^{69}$ Waters, "Alan Takes Scooter on That Final Ride."
} 
Later in life, Alan retired to Salt Spring Island, British Columbia where he wrote a column titled "Senior's Scene" for local newspaper, The Barnacle. According to residents, Alan was best known for exploring the island on his bright red scooter. He brought his camera with him wherever he went, and often wrote about his photographic practice. ${ }^{70}$ Alan viewed photography as a way of recording not only what he was doing and where he was, but also who was there with him. As he stated in one of his columns, "Every [photograph] brings back dozens of memories... and becomes a personal record forever." ${ }^{\text {11 }}$ Alan was always snapping pictures, hoping that the photographs he took would become treasured memories in the future. Little did he know, his family's albums would one day become part of the AGO's photography collection, representing much more than he could have ever imagined.

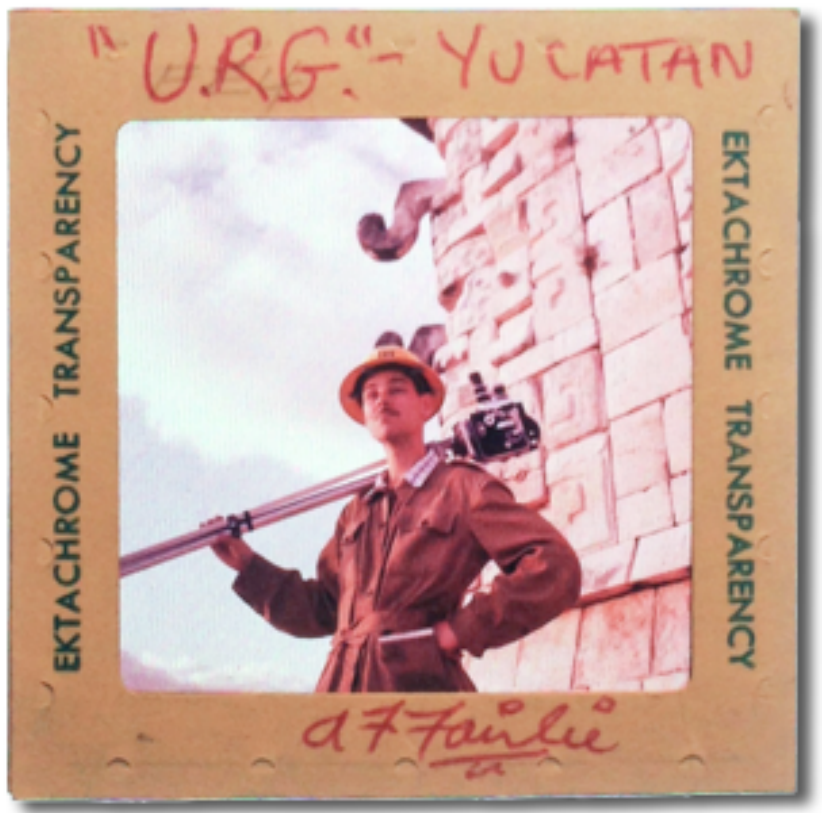

Fig. 24. Alan with his camera, Ektachrome transparency, c. 1950

\footnotetext{
${ }^{70}$ Ibid.

${ }^{71}$ Alan Fairlie, "Photos Recall Christmas Past," The Barnacle, 2000.
} 
PART II

PRACTICAL PROJET 


\section{CHAPTER 5: AGO ARCHIVES AND SPECIAL COLLECTIONS}

Each portion of the Fairlie collection is integral to the other as they provide information about members of the Fairlie family and their lives. The materials in the archival collection offer significant information that is essential in contextualizing the albums and building a biographical history for the family. The practical portion of this project addresses collections management concerns relating to intellectual and physical control, as well as access and use. Furthermore, this project raises questions regarding the needs of the materials in the collection and how they can be better managed. According to the Canadian archival standard, Rules for Archival Description (RAD), a group of documents that have been created or accumulated and used by the same person or family is called an archival fonds. ${ }^{72}$ As part of the AGO's archives and for the purpose of creating a finding aid, the collection of supporting documents and archival records is now referred to as the Fairlie Family fonds.

The Prints and Drawings (P\&D) vault at the AGO holds works on paper, which includes photographic materials, sketches, etchings, watercolours, and drawings. The collection of textual records and ephemera that came with the Fairlie acquisition was originally housed in two boxes on an unidentified shelf in the P\&D vault. These materials needed to be processed, organized, and given a proper home at the AGO. The Archives and Special Collections proved to be a more suitable space for housing and storing these materials. Although the AGO Archives is dedicated to collecting materials that are related to Canadian art and artists, the Fairlie collection provides contextual information for the photographic albums and includes a number of records and documents that are essential for understanding the family's history. Due to their significance and provenance, the archives has agreed to physically house the collection and make the finding aid accessible to staff and researchers. Although the albums and related textual collection will be housed in separate locations physically, through the practical portion of this project they will be connected and accessible through The Museum System (TMS) database.

\footnotetext{
${ }^{72}$ Diane Haglund, Using Archives: A Practical Guide for Researchers (Ottawa: National Archives of Canada, 1993).
} 


\section{CHAPTER 6: APPROACH AND METHODOLOGY}

The task of organizing, arranging, and describing the Fairlie collection has helped to draw attention to the many different aspects of this unique body of work. Each practical component of this thesis-the album inventories, updated cataloguing records, and the finding aid-required compiling information and conducting research in order to determine the most effective way of making all the elements of the collection more accessible. This portion of the project has been an essential part of not only understanding the contents of each album, but also understanding their relationship to one another. Prior to this, the collection of family documents and ephemera had not been processed, arranged, or described. In order to make these materials more accessible, the following projects were completed as part of this thesis.

\section{ALBUM INVENTORIES}

Object-level inventories have helped to provide detailed information on each of the twelve Fairlie albums and have assisted in determining the relationships between them. An archival inventory is a significant tool that allows for a detailed description of collection materials. Descriptive tools such as inventories "bring out important information about collections to guide users in [the] process of discovery." 73 The purpose of the inventories is to provide detailed information and comprehensive records on the contents and context of this body of work. As an informal finding aid, the inventories can be used as a reference tool, enabling staff and researchers to access historical and contextual information on each of the albums in the collection.

The first step in conducting the inventories was to come up with an organizational structure that included appropriate fields for describing photographic albums. In considering this, I chose comparable fields to the ones included in TMS in order to ensure consistency; however, other fields reflecting the

\footnotetext{
${ }^{73}$ Michael J. Fox and Peter L. Wilkerson, Introduction to Archival Organization and Description, ed. Susanne R. Warren (Los Angeles: Getty Information Institute, 1998), 3.
} 
nature of the collection were also included. In determining the categories, two important elements were considered: the target audience-staff at the AGO and potential researchers-and the content of the collection. For each album inventory the following elements of information were used: Location (physical location of the materials in the vault), AGO ID (an original number previously assigned to each album referencing its corresponding record in TMS), Author, Date, Title, Medium, Dimensions, Marks and Inscriptions, History (historical information about the album's context), Contents, Subject(s), and Family Members (a listing of any family members who appear in the album). The inventories connect the collection of albums by providing historical background information, content lists, and subject headings. Moreover, each album inventory provided the data necessary to update the corresponding cataloguing records in TMS (See Appendix I).

\section{CATALOGUING RECORDS}

Another component of this project is the linking of the albums in the AGO's photography collection with the Fairlie Family fonds in the Archives and Special Collections. Each individual album record has been linked digitally to the Fairlie Family fonds so that the materials, although housed in different locations physically, are interrelated and connected through the database. Prior to this project, the records in TMS for each of the albums contained a minimal amount of information and, in some cases, incorrect data. Catalogue records are helpful as they serve as a digital record of each object, series, and file in the collection and fonds. Moreover, cataloguing and documenting collection objects enriches their intrinsic value. The accumulation of information gives an object meaning and context, and results in a stronger understanding of its contribution to the collection. Cataloguing collection materials also creates a powerful tool for centralizing knowledge and is a "useful resource for knowing, accessing, and managing collection [materials]." ${ }^{74}$ After conducting historical research and studying the contents of both the albums and the archival materials, I was able to update each record to include more accurate and detailed

\footnotetext{
${ }^{74}$ Hilary Ericksen, ed. et al., The Small Museums Cataloguing Manual: A Guide to Cataloguing Object and Image Collections (Victoria: Museums Australia [Victoria]), 1990.
} 
information (See Appendix II).

The first step in the cataloguing portion of the project was to create constituent records for members of the Fairlie family who compiled albums in the collection. Prior to this project, the constituent record for each of the albums was listed as 'Unknown, Canadian, $20^{\text {th }}$ Century.' This prevented users from searching the materials accurately and easily within TMS. Creating constituent records makes it possible to form relationships within the database and assists in facilitating access and use of the materials. Records were created for Matthew F. Fairlie, Alan Fraser Fairlie, and Louis J. Fitzpatrick. With this addition, all components of the collection are now accurately represented and connected through TMS. Any record that contained incorrect data has been updated with more detailed information. A new record has also been created for the archival fonds and is also searchable through the database. This step of the project has assisted in highlighting the relationships between collection materials and has made it possible to link associated information. Cataloguing each individual photograph within the albums could not be completed as part of this project due to time constraints and is a potential project for the future.

\section{FINDING AID}

Prior to this project, the family documents and ephemera in the Fairlie collection were housed in the AGO's Prints and Drawings vault. They were stored in two boxes with no organization and, as a result, it was difficult to access and navigate through the materials. The practical component of the project began with the goal of making the documents and ephemera in the collection more accessible by intellectually organizing the materials and creating a finding aid. This not only helps to facilitate access to the materials, but creating a finding aid also allows for the opportunity to gain practical knowledge of archival processes and procedures. 
Finding aids are tools that describe collections and provide "information on the contents and context of the records, [as well as] a physical description of the materials." ${ }^{35}$ According to RAD, there are three purposes of archival description: first, to provide access to materials through retrievable descriptions; second, to promote understanding of archival material by documenting its content, context, and structure; and third, to establish authenticity of archival material by documenting its provenance and circumstances of creation and use. ${ }^{76}$ Creating a finding aid for the Fairlie Family fonds has helped to provide information on the context of the collection and has created access points to the materials contained within it.

\subsection{INTELLECTUAL ARRANGEMENT}

The first challenge I faced was figuring out how to arrange the materials. One of the fundamental principles of archival work is respect for original order. According to RAD, records should be organized in the order established or intended by the creator. Why is original order so important? Archivist Jeff O'Brien states that original order "preserves the relationships between records and any evidence that could be extracted from those relationships." ${ }^{77}$ The Fairlie materials were donated to the AGO with no original order. As a result, I had to spend a significant amount of time devising a suitable order that would facilitate arrangement, description, and access of the materials in the collection.

I began preliminary research into the organization of the finding aid, referencing those already in use at the AGO's Archives and Special Collections, as well as finding aids prepared by former FPPCM students. Moreover, I consulted resources written on maintaining collections and intellectually organizing archival materials. According to RAD, a standard hierarchy should be organized from the most general to the most specific, based on the following levels of arrangement: collection, fonds, series, file, and item. Each level of arrangement has a corresponding level of description. ${ }^{78}$ On advice from Amy Furness, Special

\footnotetext{
${ }^{75}$ Deborah Wythe, "Description," in Museum Archives An Introduction (Chicago: The Society of American Archivists, 2004$), 44$.

${ }^{76}$ Bureau of Canadian Archivists, Rules for Archival Description (Ottawa: Bureau of Canadian Archivists, 1990), xxii.

${ }^{77}$ Jeff O’Brien, Basic RAD: An Introduction to the preparation of fonds-and series-level descriptions using the Rules for Archival Description (Regina: The Saskatchewan Council of Archives, 1997).

${ }^{78}$ Bureau of Canadian Archivists, Rules for Archival Description, xxv.
} 
Collections Archivist at the AGO, I began intellectually organizing the collection by grouping together similar materials. According to archivist Terry Eastwood, "archival arrangement is essentially a process of identifying relationships, not a process of physically ordering and storing documents." ${ }^{79}$ I started to analyze the collection and divide it into suitable series based on the relationships between the materials. A series is a group of records within the fonds that is created or accumulated from the same function, activity, or subject. ${ }^{80}$ In determining the different series for this collection and their order in the finding aid, I took into consideration both the value of these materials for potential researchers as well as their use for this project. I based my series on how much historical and genealogical information each grouping contained and how significant the materials within that category are for understanding the history of the Fairlie family. The Fairlie Family fonds has been arranged into the following seven series: Family Correspondence,

Professional Correspondence, Financial and Legal Documents, Newspapers and Clippings, Photographic Materials, Amateur Film Ephemera, and Memorabilia and Personal Effects (fig. 25).

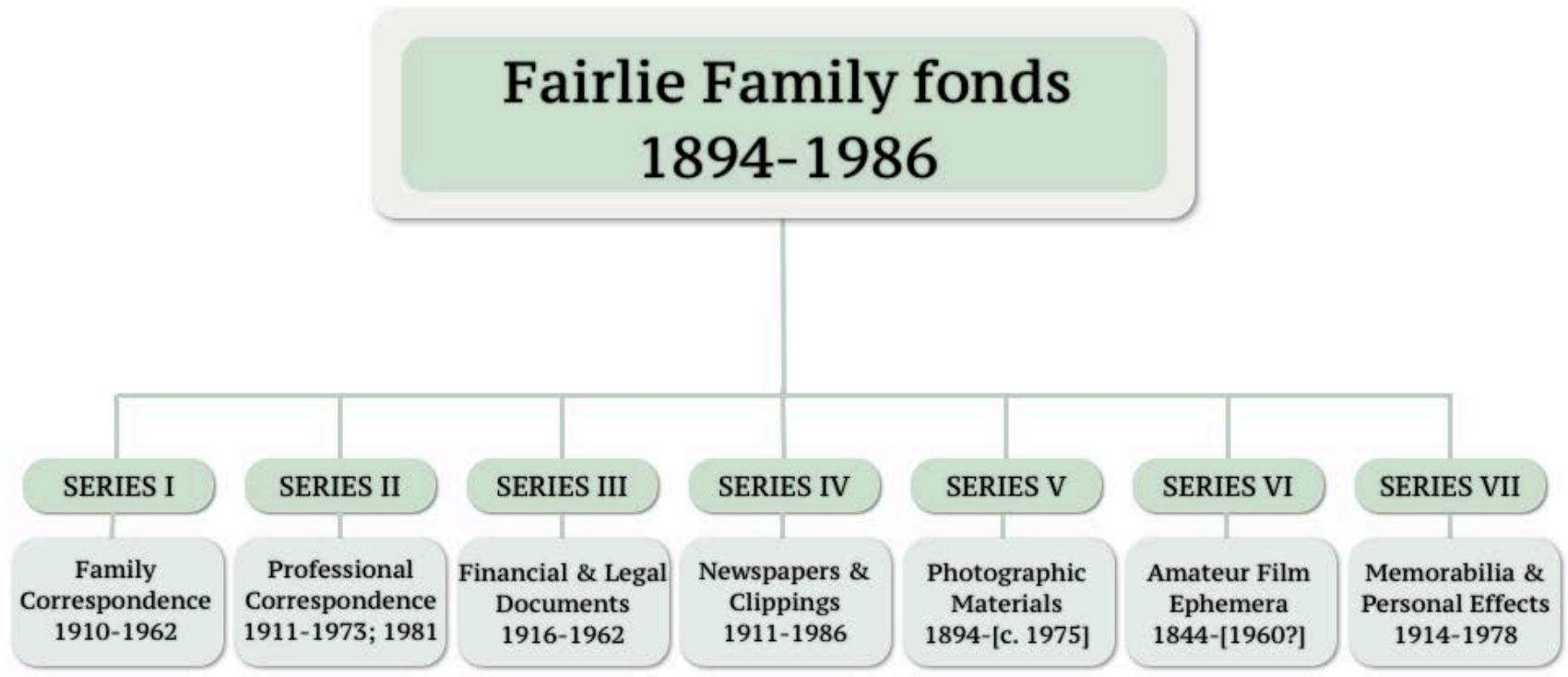

Fig. 25. Intellectual arrangement of the Fairlie Family fonds

\footnotetext{
79 Terry M. Eastwood, "Putting the Parts of the Whole Together: Systematic Arrangement of Archives," Archivaria 50 (Fall 2000 ): 93-94. Terry M. Eastwood is best known for his pioneering roles in international archival education and the creation of archival descriptive standards in Canada.

${ }^{80}$ O'Brien, Basic RAD, 6.
} 
After the basic structure of the finding aid was determined, I created a spreadsheet in Excel to assist in intellectually organizing the materials into folders, which would then be carried out in the physical arrangement as well. I listed the materials at the item level according to their corresponding series and arranged them in chronological order on the spreadsheet. The spreadsheet was a useful reference tool when it came time to physically arranging the materials.

\subsection{HOUSING \& PHYSICAL ARRANGEMENT}

After the materials were intellectually arranged into corresponding series, the next step was to start rehousing and physically arranging them. Using acid and lignin free archival storage boxes and file folders, I arranged the materials according to their corresponding series. After the collection was completely rehoused, I went through each folder labeling it with the date, box, and folder number. After completing the housing and physical arrangement, the collection was moved to the AGO Archives and Special Collections.

\subsection{WRITING THE FINDING AID}

The finding aid for the Fairlie Family fonds was structured so as to offer relevant information about the materials in the clearest way possible so that staff and researchers can access the information and crossreference it with the collection of albums. Using the standards laid out in the RAD manual, I have ensured that the arrangement and description of the collection complies with the Canadian standards. Having access to the album inventories, as well as the archival finding aid and cataloguing records, creates a better opportunity for staff and researchers to utilize the content of the collection in an effective and efficient way.

There are many elements necessary when describing a fonds, which include the following: title, dates, extent, administrative history and biological sketch, custodial history, scope and content, source of supplied title, physical description note, restrictions, accruals note, and linking elements. ${ }^{81}$ Furness

\footnotetext{
${ }^{81}$ O’Brien, Basic RAD, 15.
} 
provided me with the AGO's finding aid template, which included all of the fields necessary for the institution's standards. The finding aid for the Fairlie Family fonds begins with the dates of the collection, from the earliest to the most recent. The extent, or physical size of the collection, is provided in centimeters for textual and graphic materials and also includes the total number of photographs. Next is the biographical sketch, which explains the creator of the fonds and assists in giving context to the collection. This section provides a biography of the Fairlie family and a chronology of some of the family members' lives. In order to write this section, I began researching through the archival materials that were included with the collection. I also pieced together information that I gathered through analyzing the albums and by consulting with various archival organizations such as the University of Toronto Archives, Upper Canada College Archives, and The Salt Spring Island News.

The information at the fonds level is described in the most general way possible. The series and file levels of description include many of the same elements as listed above, but are more specific. At the series level it is important that the scope and content descriptions relate only to that body of work. The same is true when describing the contents at the file level. The completed finding aid is included as an appendix. (See Appendix V on page 64). 


\section{CHAPTER 7: CONCLUSION}

Photography has played a pivotal role in helping people to preserve their memories and identities. In the same sense, the family album has functioned as a method of recording, organizing, and preserving certain aspects of life, allowing people to become the author of their own story. As part of this thesis, it is important to consider the changing contexts of these objects, as they become part of public collections. When viewed in a new context, family albums become part of a much larger narrative-one that includes sociological, historical, and cultural perspectives. We can begin to draw assumptions based on how a particular family chose to photograph and document their lives over a significant period of time. As public art collections and museums continue to show a growing interest in family snapshots and albums, the meaning of these objects continues to change.

Family albums are unique objects that tell us not only about a specific family, but also about a particular time and place in history. As part of public collections, photographic albums have what Martha Langford refers to as an afterlife-they move from "visible world to photograph; photograph to album; private album to public realm; public realm to individual reception." ${ }^{82}$ Even photographs whose stories have been almost forgotten can provide clues into how a particular family chose to document their passions and their dreams on the pages of an album. The afterlife of the Fairlie albums-how the collection made its way to the AGO and what it means today-forces us to consider what happens to all vernacular albums once they are separated from the hands of their maker. This project helps to better understand the lives of family albums and what information these objects can offer to us as part of both public and private collections.

Photographs and family albums not only assist in showing, but also in telling about past experiences. As Langford points out, photographs, and collections of them in particular, represent a constructed world through which certain moments can be recalled. A central theme of this thesis is the

\footnotetext{
${ }^{82}$ Ibid., 19.
} 
formation of narratives-through photographs, albums, scrapbooks, and films. Each of these has an identity and purpose that is linked to the preservation of personal and family memories. These forms of visual communication assist in transferring experiences from one person to another through time and through history. While removed spatially and temporally from the people depicted, the Fairlie albums allow for a connection to exist between generations. ${ }^{83}$ The expressive qualities of family albums, and the multitude of ways in which they reflect individual and cultural values, makes these objects valuable in a number of different contexts. ${ }^{84}$

In the process of completing this project, a relationship has been established between the twelve Fairlie albums. Examining the collection as a whole has helped to better understand the family's response to the numerous changes taking place in Canada during the first half of the twentieth century. The research and analysis conducted on each album, along with the finding aid, object-level inventories, and cataloguing records, provides insight into the Fairlie's photographic practice and forms a case study for examining, understanding, and accessing vernacular objects in public collections. This project provides the Art Gallery of Ontario with strategies for processing, describing, and creating relationships for collections that are comprised of both photographic objects and archival materials. Moreover, this body of work provides a rich resource for furthering our knowledge and scholarly study of snapshot photography and family albums in a Canadian context.

\footnotetext{
${ }^{83}$ Rodney G.S. Carter, "Photography and Personal Mythology," Queen's Quarterly, 114, no. 4 (Winter 2007): 8.

${ }^{84}$ Levine and Snyder, Snapshot Chronicles, 188.
} 
APPENDICES 


\section{APPENDIX I: ALBUM INVENTORIES}

AGO ID: AGO.102886

Institution: Art Gallery of Ontario

Location: CS 6, Bay $1: \mathrm{sb} 82$

Author: Alan Fraser Fairlie

Date: 1950

Title: "The Personal Record of a Good Will Ambassador"

[Travel Scrapbook by Alan Fraser Fairlie]

Medium: Album: 8 real photo postcards, 17 gelatin silver prints and 79 postcards on 78 unbound pages

with ribbon

Dimensions: Album: 35.6 x 30.1 x $3.5 \mathrm{~cm}(14 \times 117 / 8 \times 17 / 16$ in $)$

$\operatorname{Mark}(s)$ :

Inscriptions: Page 1, C, black paint: Canada; BC, black paint: The Personal Record/of a good will ambassador!/... and the light she shed on the Dark Continent...!/1950

\section{History:}

A scrapbook compiled by Alan Fraser Fairlie of an 85-day cruise trip beginning on March 23, 1950. Alan F. Fairlie was travelling aboard the Queen Mary cruise ship as a first class passenger. Departing from New York, the ship travelled to South Hampton, London. Landmarks visited while there included: Grosvenor House, Westminster Abbey, St. Paul's Cathedral, and Piccadilly Circus. The Union Castle Line, "Bloemfontein Castle," is the name of the ship Alan F. Fairlie would spend nine weeks aboard, travelling to 3 continents, 15 countries, and 18,700 miles. Departing from London, England, the ship made stops in: Las Palmas, Spain; the tropical island of St. Helena; South and East Africa, where Alan F. Fairlie visited Cape Town, Port Elizabeth, East London, Durban, Mozambique, Beira and Zanzibar; the city of Mombasa in Kenya; the city of Aden in Yemen located in Southwest Asia; Port Sudan; Cairo, Egypt; Genoa and Portofino, Italy; and lastly before returning to London, Marseilles, France. After returning to England in August, Alan F. Fairlie explored London, which he called "the largest city in the world," before travelling back to New York and eventually returning to his hometown of Toronto, Ontario.

\section{Contents:}

This scrapbook includes Alan F. Fairlie's boarding pass from the Queen Mary and accompanying luggage tag, embarkation notice for Union Castle Line, March 24, 1950, ten postage stamps from various destinations, souvenirs including: silver leaves from South Africa; various paper cutouts; Union Castle Line dinner menu; a pamphlet containing travel tips and a map of South Africa; Deavin's Florist, South Africa delivery card signed by Susan (Alan's wife); Union Castle Line boat ticket; various drawings by Alan F. Fairlie; South African dollar bill; Zanzibar Tour Excursion pamphlet; receipt from Shepheard's Hotel, Egypt; 2 mini photographic souvenir books of Italy; "Westminster Memories" booklet; Victoria League House welcome letter; various newspaper clippings; bank-issued tax-free coupons; and, a movie stub from Tom Arnold's film, "Rosy Mary"

\section{Subject(s):}

Scrapbooks;

Travel;

Family Members:

Alan Fraser Fairlie 
AGO ID: AGO.102887

Institution: Art Gallery of Ontario

Location: CS 6, Bay $1: \mathrm{sb} 83$

Author: Matthew Fraser Fairlie

Date: c. 1922, two photographs dated to 1935

Title: "Picturesque Silverland" [Ontario Travel and Mining Album]

Medium: Album: 22 gelatin silver prints on 38 pages in a tan cloth album

Dimensions: Album: $15 \times 19.3$ x $0.8 \mathrm{~cm}$ (5 7/8 x 7 5/8 x 5/16 in)

$\operatorname{Mark}(s)$ :

Inscriptions: Front cover, BC, silver pen: Picturesque Silverland

\section{History:}

A photographic album compiled by Matthew F. Fairlie documenting a trip to New Liskeard and surrounding areas. New Liskeard is located on the northwestern end of Lake Temiskaming and merged with the town of Haileybury in 2004 to create, which is now known as, the city of Temiskaming Shores. The photographs in the album document various town sites, landscapes, and mining communities throughout northern Ontario. The photographs of mining sites include Foster Silver Mine, located in Cobalt, Ontario and Ashley Gold Mines Ltd., a mining company which operated out of Matachewan, Ontario. Also included in the album are photographs depicting the town of Haileybury before and after the Great Fire of 1922.

\section{Contents:}

According to handwritten captions by Matthew F. Fairlie, the photographs depict the following: "Canada House," which was located in New Liskeard at the time; The Main Street of New Liskeard; Haileybury Train Station; Ferguson Avenue, Haileybury, "Before the Fire”; Haileybury's mascot, a small pony; Foster Mine; [Missing Mine?]; Ashley Gold Mines Ltd.; Fort Temiskaming; “The Old Mission," Lake Temiskaming, referring to the Old Mission Resort in Cobalt, Ontario

\section{Subject(s):}

Mining;

Ontario;

Travel;

\section{Family Members:}

Matthew Fraser Fairlie 
AGO ID: AGO.102890

Institution: Art Gallery of Ontario

Location: CS 6, Bay $1: \mathrm{sb} 86$

Author: Alan Fraser Fairlie

Date: 1936 - 1942

Title: "Snapshots" [Alan Fairlie]

Medium: Album: 79 gelatin silver prints on 48 pages in a brown and orange album with string binding

Dimensions: Album: 7.5 x 21 x $2 \mathrm{~cm}(215 / 16$ x 8 1/4 x 13/16 in)

Mark(s): Front cover, TL, gold: Snapshots

Inscriptions: Front cover, C, pencil: Alan Fairlie

\section{History and Contents:}

A photographic album depicting various travel destination around Ontario. Photographs include the following: documentation of a 1937 trip to the "family camp" in Niagara Falls, Ontario; Alan and Joy horseback riding; and various photographs of Jock, the family dogs Alan in his Crescent School uniform, the Fairlie home and outside activities at Shorncliffe Ave., Toronto, photographs taken "en route to Montreal," Alan Fairlie at Camp Temagami; Big Bay Point on Lake Simcoe; and Welland Canal.

Subject(s):

Family;

Toronto;

Montreal;

Ontario;

\section{Family Members:}

Joyce Fairlie

Alan Fraser Fairlie

Catherine Fraser, "Aunt Cathy" 
AGO ID: AGO.102891

Institution: Art Gallery of Ontario

Location: CS 6, Bay $1:$ sb 87

Author: Louis J. Fitzpatrick

Date: 1880 - 1910

Title: [Family Photographs form the 1890s]

Medium: Album: 236 gelatin silver prints and 1 cyanotype on 96 pages in black album

Dimensions: Album: 32.2 × 25.5 x $3.4 \mathrm{~cm}$ (12 11/16 x $101 / 16$ x 1 5/16 in)

$\operatorname{Mark}(s)$ :

Inscriptions:

\section{History and Contents:}

An early photographic album comprised of snapshots depicting the Fairlie and Fitzpatrick families.

Photographs document the following: Matthew F. Fairlie with Anne Louise Fairlie in Ottawa before they were married; various snapshots of family pets; photographs depicting members of the Fitzpatrick family in fashionable attire, presumably taken in Kingston, Ontario where they resided; an unknown wedding ceremony; various landscape shots; photographs taken on a ship during a trip to the United Kingdom.

Subject(s):

Vacation;

Snapshots;

Photographs;

Albums;

Vernacular;

Family;

Ottawa;

Kingston;

Ontario;

\section{Family Members:}

Louis J. Fitzpatrick

Anne Louise Fairlie

Matthew Fairlie 
AGO ID: AGO.102892, AGO.102893, AGO.102894, AGO.102895

Institution: Art Gallery of Ontario

Location: CS 6, Bay 1:sb 89 (1 box)

Author: Camp Temagami

Date: 1939 - 1946

Title: Camp Temagami

\section{Medium:}

AGO.102892: Album: 19 silver gelatin photographs bound with string AGO.102893: Album: 17 silver gelatin photographs bound with string AGO.102894: Album: 14 silver gelatin photographs bound with string AGO.102895: Album: 14 silver gelatin photographs bound with string Dimensions: Albums: $11 \times 21.4 \times 1 \mathrm{~cm}(45 / 16 \times 8$ 7/16 x 3/8 in.)

Mark(s): Front cover, C, black stamp: Camp Temagami and the creation date Inscriptions:

\section{History and Contents:}

Each of the four albums includes photographs taken at Camp Temagami in Northern Ontario between the years of 1939 and 1946. Camp Temagami was an all-boys wilderness camp that Alan Fraser Fairlie attended as a child. Activities depicted in the albums include: boating, canoeing, horseback riding, and fishing. The albums were given to campers as a souvenir of their summer camping experiences.

\section{Subject(s):}

Summer camp;

Travel;

Campfires;

Outdoor life;

Ontario, Northern;

\section{Family Members:}

Alan Fraser Fairlie 
AGO ID: AGO.102896

Institution: Art Gallery of Ontario

Location: CS 6, Bay $1: \mathrm{sb} 89$

Author: The Fairlie Family

Date: [1910 - 1930]

Title: [Fairlie Snapshot Album]

Medium: Album: 334 gelatin silver prints and 132 pages in a dark green album with painted cover

Dimensions: Album: 28.8 x 22.3 x $4 \mathrm{~cm}(115 / 16$ x 8 3/4 x 1 9/16 in)

Mark(s): Front cover, TC, gold: Post Cards

Inscriptions:

\section{History:}

An album compiled over a twenty-year period from approximately 1910 to 1930 . The photographs are snapshots depicting various members of both the Fairlie and Fitzpatrick families. The album includes photographs taken in Cobalt and Haileybury, which depict various silver-pouring events, mining staff members, equipment and sites around the northern Ontario region. Also included are photographs of the interior of the Fairlie's home when they lived in Cobalt from the early twentieth century to 1930. Photographs include snapshots of various family members at Dawson's Point and other destinations in Kingston, Ontario. This album also includes various photographs from Ottawa of Matthew and Anne Louise and other family members, specifically Matthew's brother, William Alexander Fairlie, his wife Ethel, and their children. This album also includes photographs of the Fitzpatrick family: Anne Louise's brother, Louis Fitzpatrick, his wife Ethel (Pinkham) and their two sons, Louis and James "Jimmy."

\section{Contents:}

Photograph labeled, "Fairlie Boys" includes Matthew Fraser, Thomas Urquhart, John, James and William Alexander Fairlie.

\section{Subject(s):}

Vernacular;

Travel;

Family Members:

Matthew Fraser Fairlie

Anne Louise Fairlie (Fitzpatrick)

Louis Fitzpatrick

Ethel Fitzpatrick (Pinkham)

Alan Fraser Fairlie

Joyce Fairlie

Reverend John Fairlie

Hannah Muldrup Fairlie (Fraser)

Thomas Urquhart Fairlie

John Fairlie

James Fairlie 
AGO ID: AGO.102897

Institution: Art Gallery of Ontario

Location: CS 6, Bay $1: \mathrm{sb} 89$

Author: Matthew F. Fairlie

Date: 1930 s

Title: [Fairlie Snapshot Album]

Medium: Album: 488 gelatin silver prints and 3 gelatin silver prints with applied colour on 100 pages in a black album

Dimensions: Album: 18 x 29.8 x 5 cm (7 1/6 x $113 / 4$ x 1 15/16 in.)

Mark(s): Front cover, TL, silver: Photographs

Inscriptions: Front cover, BR, illegible (faded)

\section{History \& Contents:}

A photographic album documenting Alan and Joyce during their childhood. The snapshots contained within the album depict Joyce at Glen Bernard Camp in 1937, images of the Fairlie family's dog Jockie, studio portraits of Alan and Joyce as children, vacation trips to Rostrevor, Big Bay Point, and Temagami, photographs taken at home in Toronto, images of family members during holiday gatherings, Alan and Joyce in their school uniforms, and images of the inside of the Fairlie's home on Shorncliffe Ave., 1939.

\section{Subject(s):}

Vernacular;

Camp;

Vacation;

Ontario;

Toronto;

Family Members:

Alan F. Fairlie

Joyce Fairlie

Matthew F. Fairlie

Anne Louise Fairlie 
AGO ID: AGO.102898

Institution: Art Gallery of Ontario

Location: CS 6, Bay $1: \mathrm{sb} 89$

Author: Louis J. Fitzpatrick

Date: 1900 s - 1920s

Title: [Album of Louis J. Fitzpatrick]

Medium: Album: 204 gelatin silver photographs and 3 cyanotypes in a black album

Dimensions: Album: 18.6 x 28 x $2.5 \mathrm{~cm}$ (7 5/16 x 11 x 1 in.)

$\operatorname{Mark}(s)$ :

Inscriptions: Inside font cover, TL, black: Louis J. Fitzpatrick/404 Laurier Ave. East/Ottawa, Ontario/Xmas 1906 A.L.F

\section{History \& Contents:}

An early snapshot album containing photographs of the Fitzpatrick family. Images depict family members in very fashionable attire in while in Kingston and Ottawa. Photographs include the Fitzpatrick's home, family pets, horse and carriage, photographs taken while on a trip to the United Kingdom in the early twentieth century.

\section{Subject(s):}

Vernacular;

Kingston;

Ottawa;

\section{Family Members:}

Louis J. Fitzpatrick

Anne Louis Fairlie 
AGO ID: AGO.102899

Institution: Art Gallery of Ontario

Location: CS 6, Bay $1: \mathrm{sb} 89$

Author: Kerr-Addison Gold Mines Ltd.

Date: 1938 - 1941

Title: Photographs of Kerr-Addison Gold Mines LTD From Bush to Bullion

Medium: Album: 190 gelatin silver photographs on 96 pages in a black album

Dimensions: Album: 26 x 33.1 x $2.3 \mathrm{~cm}$ (10 1/4 x $131 / 16$ x 7/8 in.)

Mark(s): Front cover, C, gold: Photographs

Inscriptions: Page 1, C, white pencil: Photographs/ of/ Kerr-Addison Gold Mines Ltd./ From Bush to Bullion

\section{History:}

Matthew F. Fairlie attended Queens University and graduated in 1903. He moved with Cobalt with his wife Anne Louise to work as a Mining Engineer for Kerr Addison Gold Mines Ltd. during the Silver Rush and stayed in Cobalt until the 1920s. The Kerr-Addison Mine was located in Virginiatown, Northern Ontario and at one time was Canada's largest gold producing mine.

\section{Contents:}

A photographic album compiled by Kerr-Addison Gold Mines Ltd. between the years of 1938 and 1941 . Photographs have been carefully laid out, each captioned with the mining site and date it was taken. The images depict various plants, sites, landscapes, and employees associated with Kerr-Addison Gold Mines Ltd. The last few pages of the album includes photographs that have been collaged closely together with small black photo-corners depicting similar subject matter, including: "Staff Residence, 1940," "South End of Mill," and the "Fairlie Mining Lodge."

\section{Subject(s):}

Mining;

Ontario;

Industrialization;

Family Members:

Matthew Fraser Fairlie 


\section{APPENDIX II: TMS CATALOGING RECORDS}

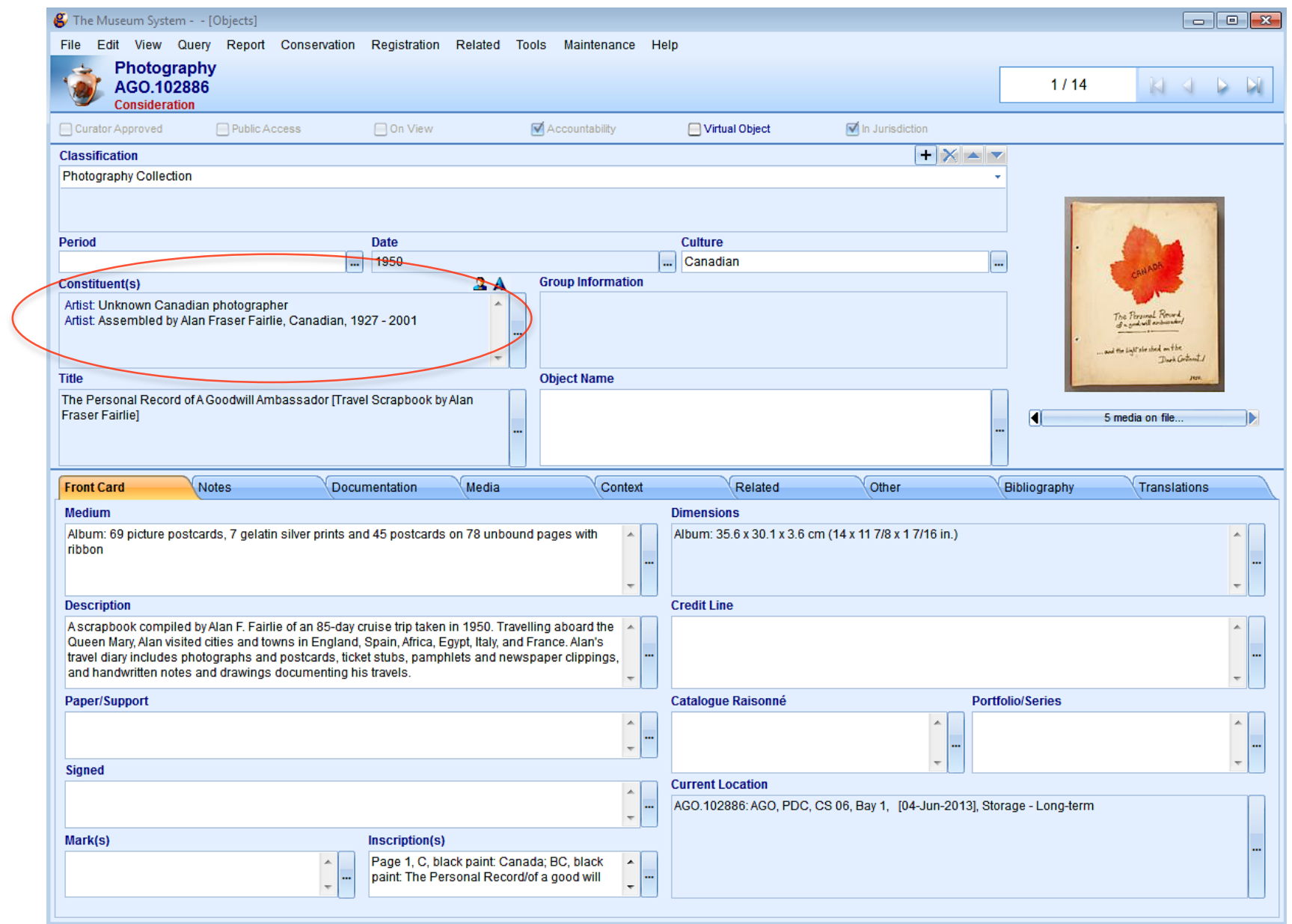

TMS Catalogue Record, AGO.102886

Each album record includes additional information in the description field, as well as newly linked constituent records.

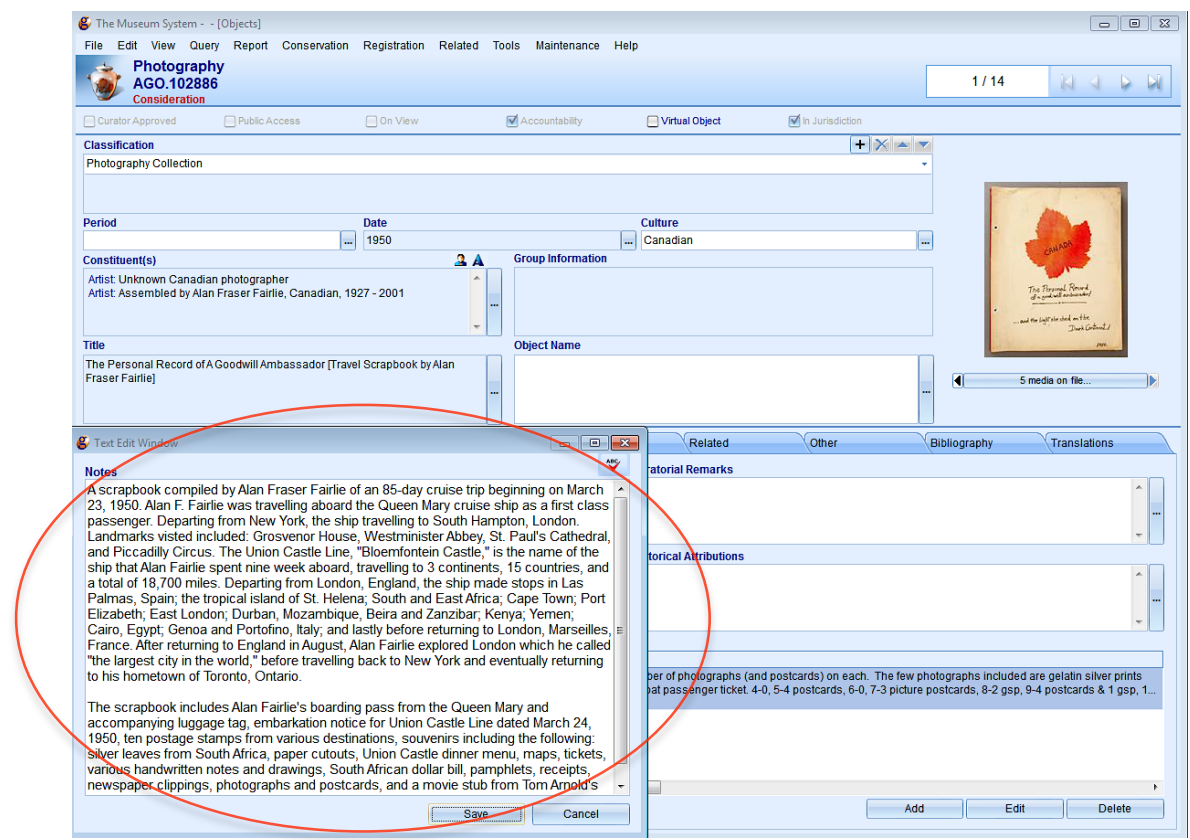

TMS Catalogue Record, AGO.102886 Historical information about the contents of each album has been included in the notes field of the corresponding record. Refer to the related object-level inventories for more information. 


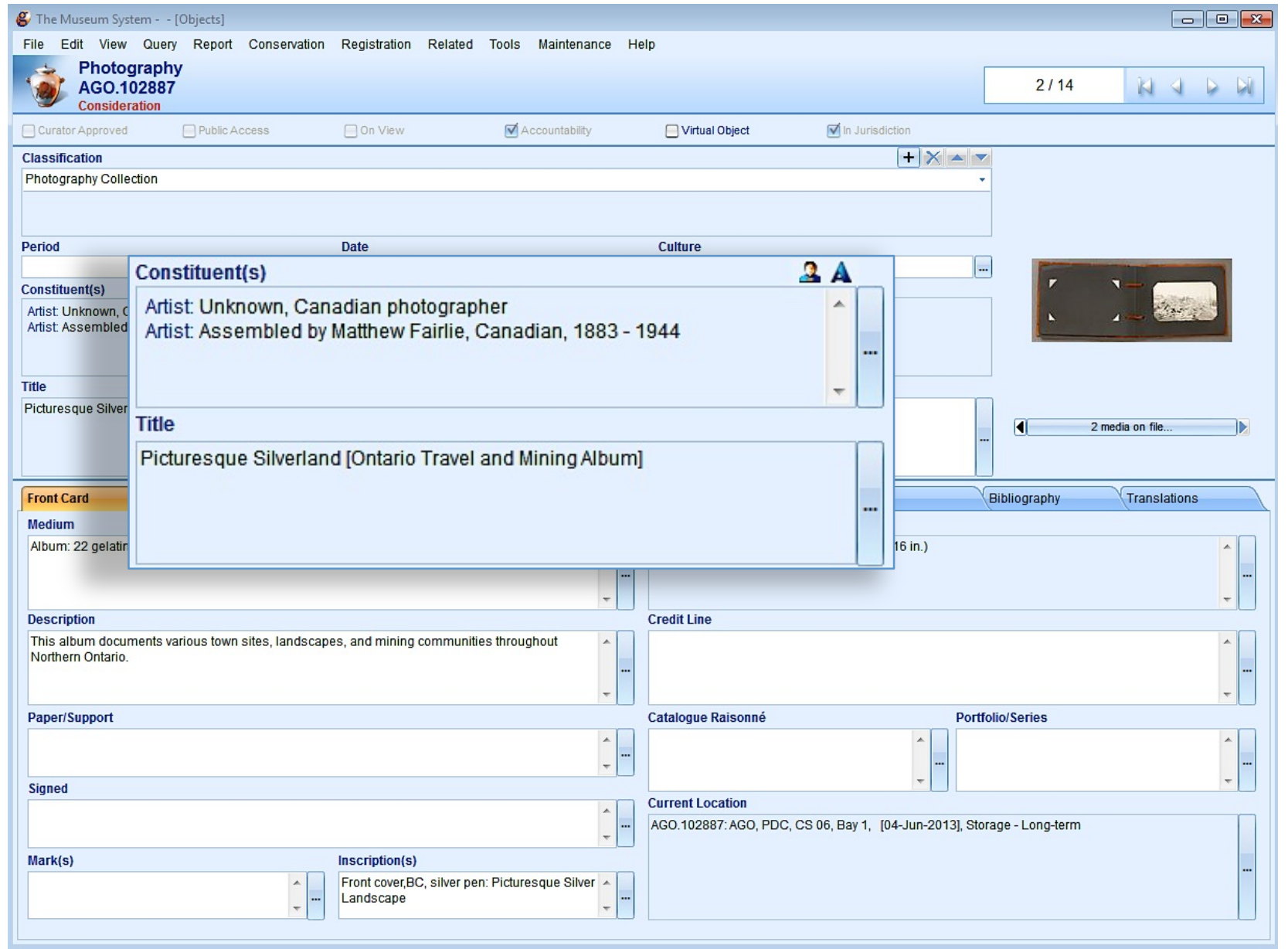

TMS Catalogue Record, AGO.102887

Each record has been updated with correct information. This includes the spelling of Fairlie-which was incorrectly spelt prior to this project—as well as more descriptive and accurate titles for each album. 


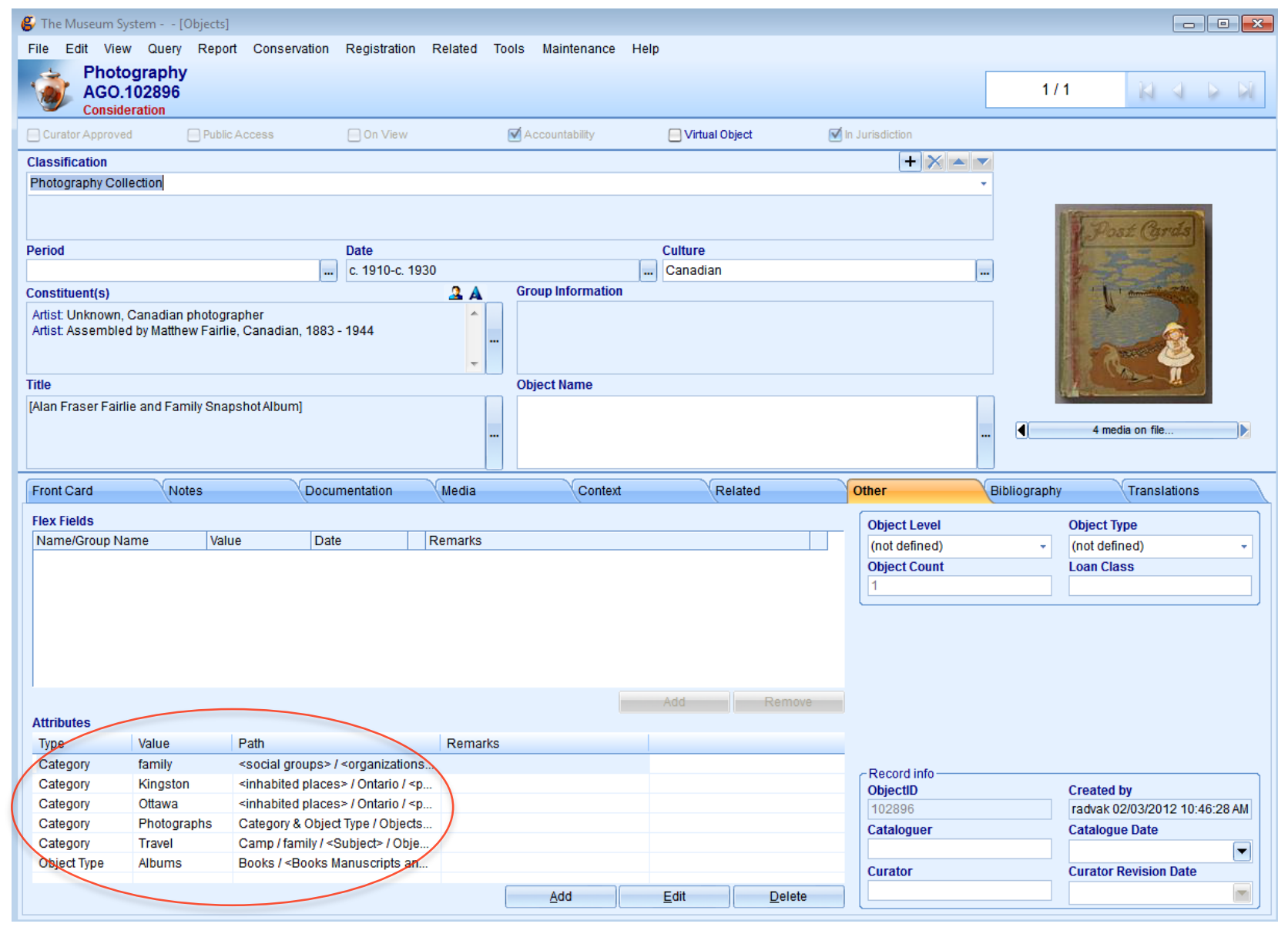

TMS Catalogue Record, AGO.102893

Additional search terms have been added for each TMS record. The subjects are based on the contents of each album. In this case, subject headings include the following: Family, Kingston, Ottawa, Photographs, Travel, and Albums. 


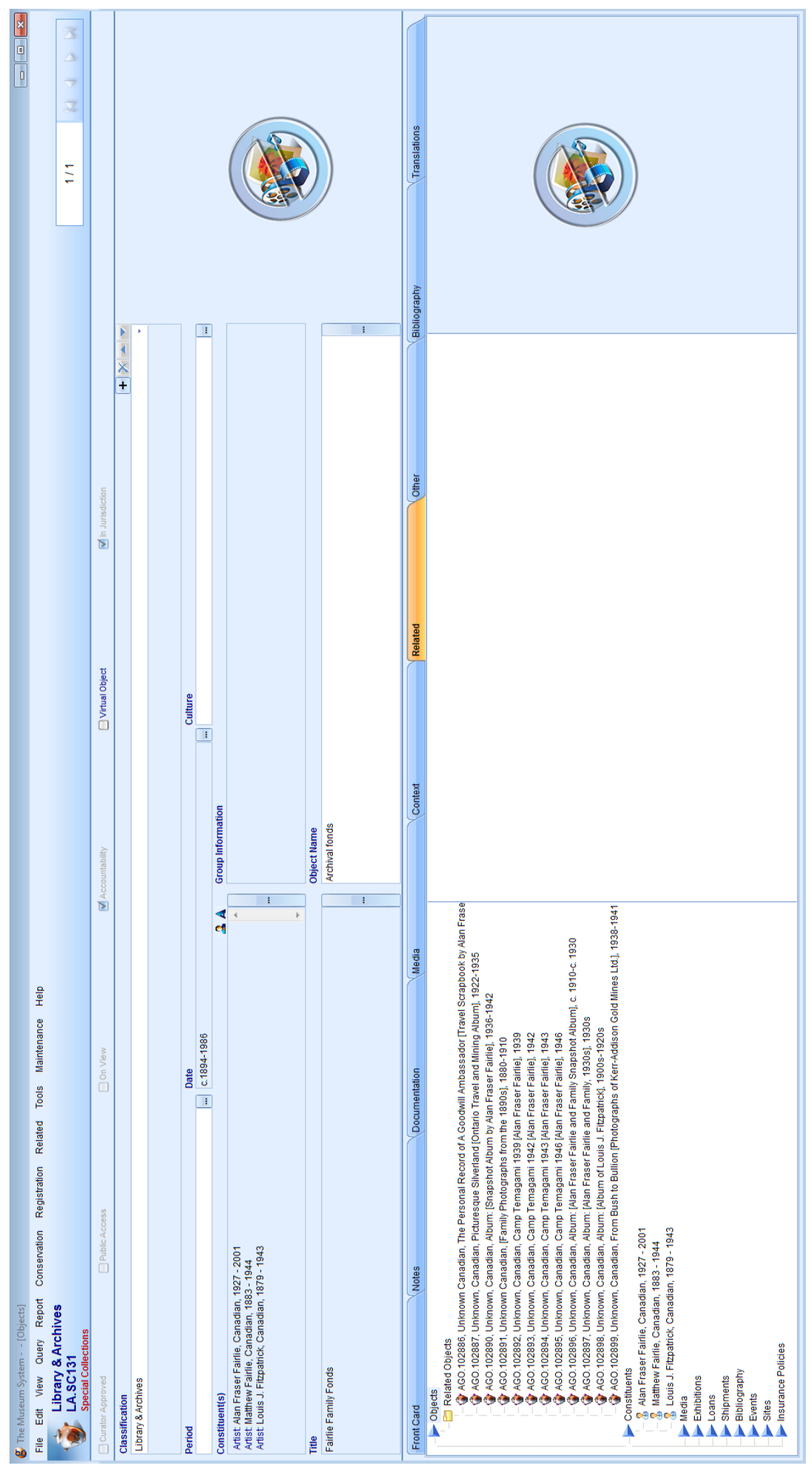

TMS Cataloguing Record, LA.SC131

A new record has been created in TMS for the Fairlie Family fonds (LA.SC131). This record has been linked in TMS with the album and constituent records under the 'related' field tab. 


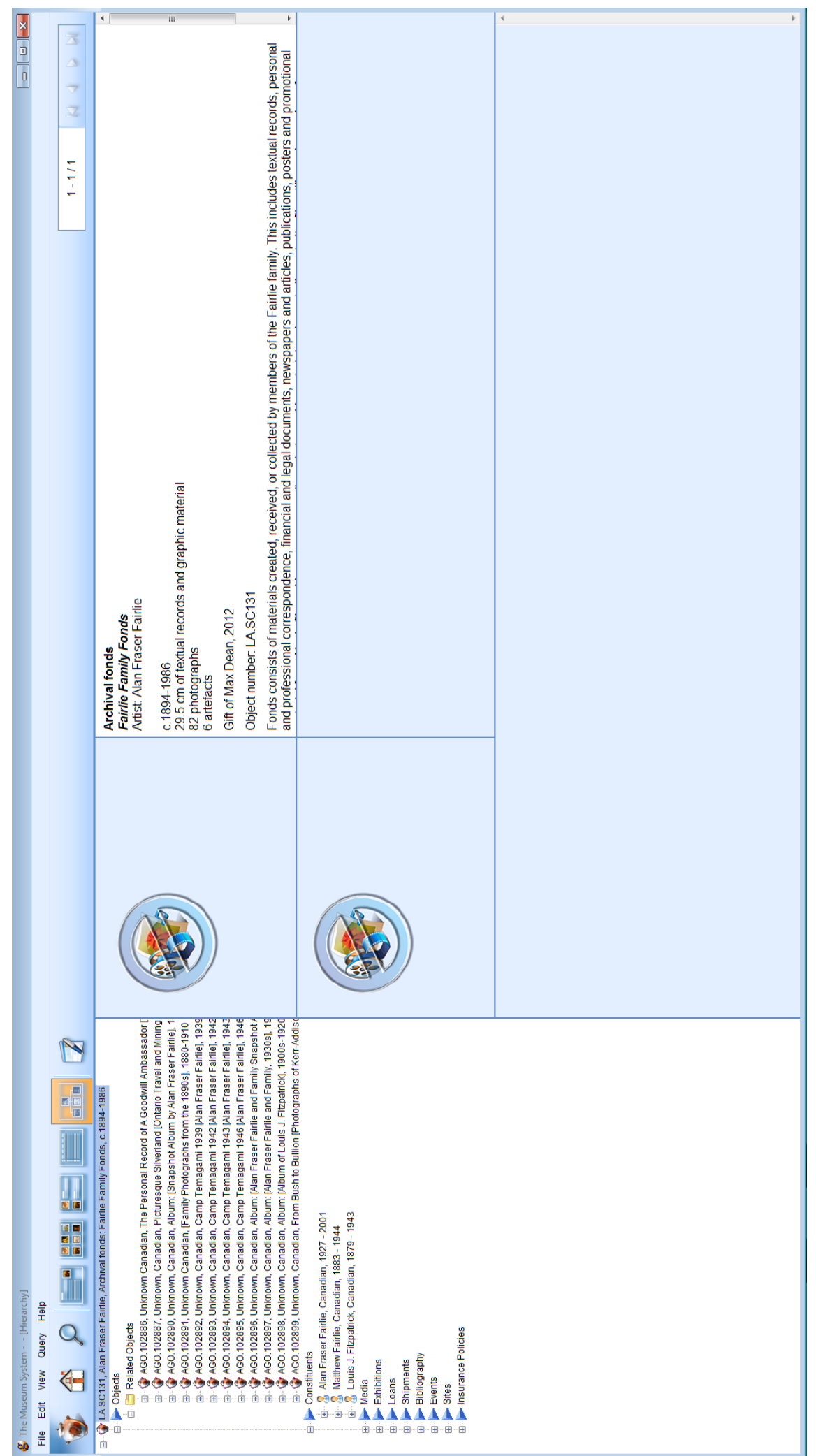

TMS Cataloguing Record, LA.SC131

A hierarchy has been created between the records in TMS, which outlines the relationships that exist between all components of the collection-objects, constituents, and the archival fonds. 
APPENDIX III: FAIRLIE FAMILY TREE

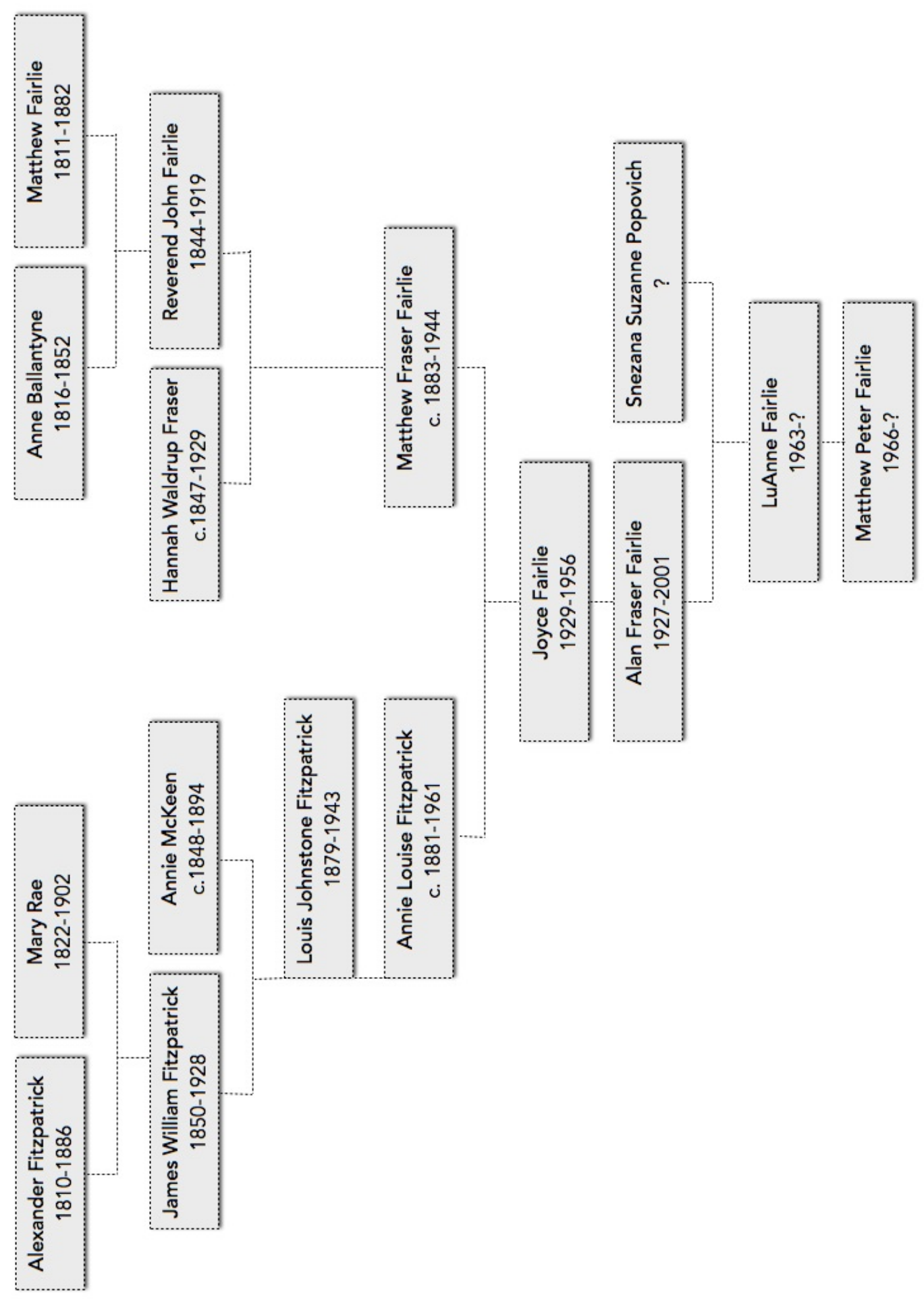




\section{APPENDIX IV}

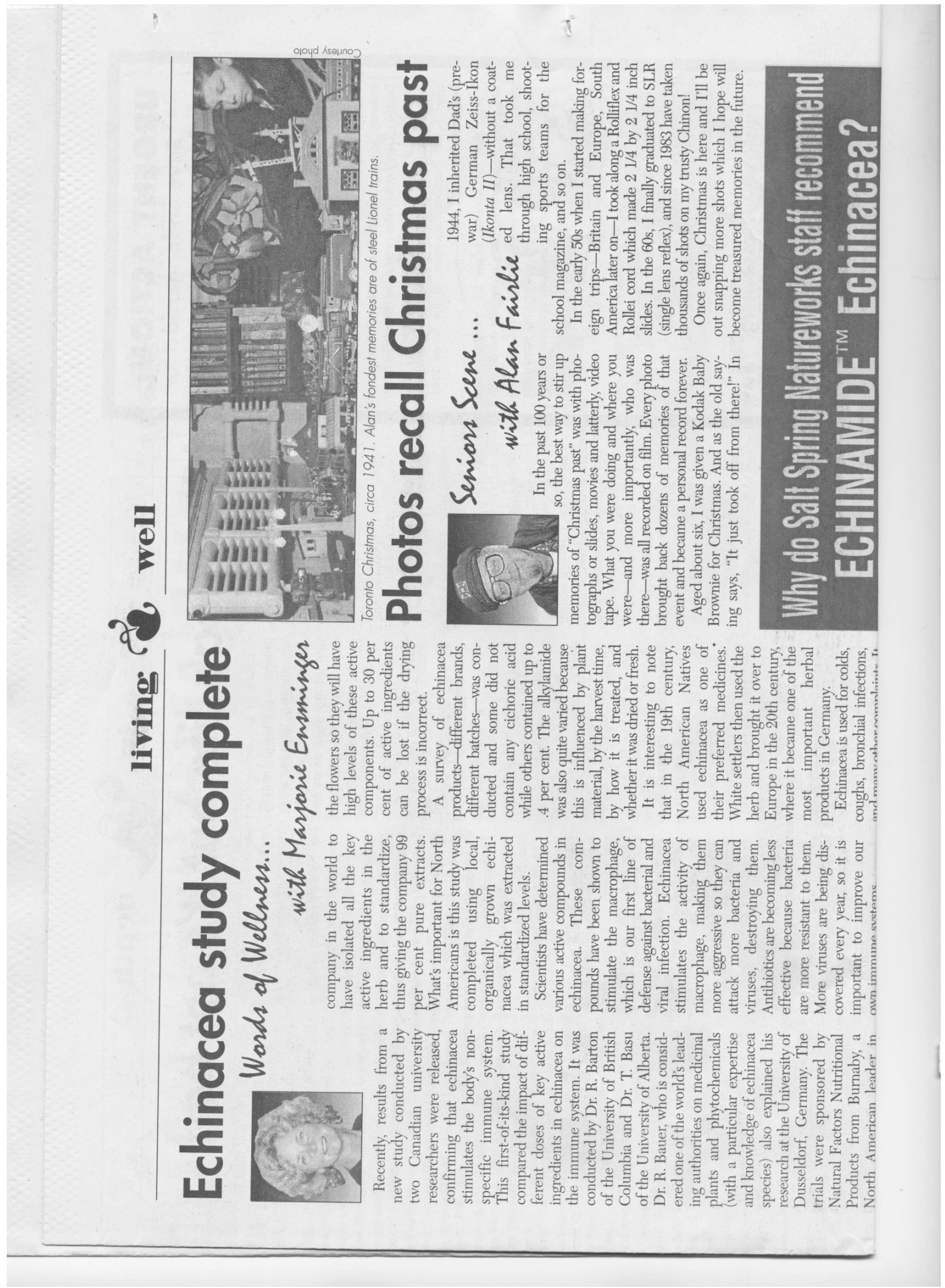

Copy of "Photos Recall Christmas Past," written by Alan F. Fairlie, Published in The Barnacle newspaper, November 28, 2000. Image courtesy of Driftwood Gulf Island Media. 
E.P. Taylor Research Library \& Archives

\section{Description \& Finding Aid: \\ Fairlie Family Fonds \\ CA OTAG SC131}

Prepared by Laura Gentili, 2015 


\section{Fairlie Family fonds}

\section{Dates of creation:}

ca. $1894-1986$

\section{Extent:}

$29.5 \mathrm{~cm}$ of textual records and graphic material

82 photographs

6 artefacts

\section{Biographical sketch:}

The Fairlies were a prominent Canadian family who lived and worked throughout Ontario during the first half of the twentieth century.

Reverend John Fairlie (1844-1919) and his wife Hannah Waldrup Fraser (ca. 1847-1929) came from Scotland to Quebec in 1873, then to Kingston in 1900. They had nine children-four girls and five boys. One of their sons, Matthew Fraser Fairlie (ca. 1883-1944), attended Queens University in Kingston, Ontario. He graduated in 1902 with a Bachelor's Degree in Mining Engineering and moved to Cobalt, Ontario with his wife, Anne Louise Fitzpatrick (ca. 1881-1961) to work for Kerr-Addison Gold Mines Ltd. during the Silver Rush of 1903. They moved to Toronto in the late 1920s, purchased a house in Forest Hill, and adopted two children: Alan Fraser Fairlie (1927-2001) and Joyce Fairlie (1929-1956). Alan attended both Crescent School and Upper Canada College (ca. 1935-1948), two prestigious all-boys private schools in Toronto. Joyce attended Bishop Strachan School for girls (ca. 1935-?).

After attending the University of Toronto for Radio Broadcasting (1949-?), Alan F. Fairlie started a film company, Monarch Productions Ltd. He was commissioned to produce films for the Canadian Rugby team in Bermuda, the development of Giant's Tomb in Penetang, Ontario, and various programs for CTV Television Network. He also shot and produced his own films documenting archaeological caves in Yucatan, his travels to Mexico, and footage in various countries throughout Europe. Alan married Snezana Susanne Popovich in 1962. They had two children: LuAnne Fairlie (1963-) and Matthew Peter Fairlie (1966-). Alan retired to Salt Spring Island, British Columbia where he lived until his death in 2001.

\section{Scope and content:}

Fonds consists of materials created, received, or collected by members of the Fairlie family. This includes textual records, personal and professional correspondence, financial and legal documents, newspapers and articles, publications, posters and promotional material from Alan's filmmaking career, as well as photographic material such as studio portraits, film stills, and a number of negatives depicting travel destinations and events.

\section{Contains series:}

1. Family Correspondence

2. Professional Correspondence

3. Financial and Legal Documents

4. Newspapers and Clippings

5. Photographic Materials

6. Amateur Film Ephemera

7. Memorabilia and Personal Effects 


\section{Custodial history:}

Toronto-based artist Max Dean purchased the Fairlie materials at an antique market in Toronto. From approximately 1992 to 2012, he amassed a collection of over 600 photographic albums. After years of collecting albums from various places, Dean realized that he had more albums than he could properly care for. He allowed the Curators of Photography at the AGO to make a selection of albums, which he later donated to the AGO's photography collection in 2012. The Fairlie collection is the largest concentration within the larger acquisition of 237 albums. The fonds was transferred from the AGO's Prints and Drawings vault to the Archives and Special Collections; the 12 albums remain in the AGO's photography collection.

\section{Notes:}

Source of title proper:

Title based on the contents and provenance of the fonds.

Immediate source of acquisition:

Gift of Max Dean, 2012

Arrangement:

The fonds has been arranged by the archivist following the original order of the creator where possible.

Restrictions on access:

Open. Access to Special Collections is by appointment only. Please contact the reference desk for more information.

Terms governing use and reproduction / publication:

Various copyright holders. Some material in this fonds/collection is in the public domain. Permission of the Art Gallery of Ontario is required for publication. Copyright belonging to other parties, such as that of photographs, may still rest with the creator of these items. It is the researcher's responsibility to obtain permission to publish any part of the fonds/collection.

\section{Associated material:}

There are 12 photographic albums compiled and collected by the Fairlie family in the Art Gallery of Ontario's permanent collection donated by Toronto-based artist Max Dean in 2012. The administrative file also includes 7 photocopied issues of "Senior's Scene," a column written by Alan F. Fairlie for The Barnacle newspaper from 1999 to 2001; an acquisition report written by Associate Curator of Photograph, Sophie Hackett; and, the Fitzpatrick/Fairlie family tree.

Accruals:

No further accruals are expected.

\section{Provenance access point:}

The Fairlie Family (Toronto, ON)

Fairlie, Alan Fraser (1927-2001)

Fairlie, Matthew Fraser (ca. 1883-1944)

Fitzpatrick, Louis J. (1879-1943) 


\section{SERIES 1: FAMILY CORRESPONDENCE}

\section{Dates of creation:}

$1910-1962$

\section{Extent:}

$2.5 \mathrm{~cm}$ of textual records and graphic material

\section{Scope and content:}

Series consists of personal correspondence sent to and from members of the Fairlie family.

\section{Notes:}

Arrangement:

Arranged chronologically by archivist.

\section{File list:}

FILE TITLE

Letters

greeting cards

\section{START END CONTENTS}

DATE DATE

1910

1962

1962 Joyce.
Letters are between members of the immediate

BOX-

FOLDER \#

$1-1$ family, including letters written from Matthew F. Fairlie to his brother, mother, and father. Also included are letters from Matthew and Anne Louise Fairlie to their children Alan and

File includes greeting cards from various $1-2$

\section{SERIES 2: PROFESSIONAL CORRESPONDENCE}

\section{Dates of creation:}

1911 - 1973; 1981

\section{Extent:}

$1.5 \mathrm{~cm}$ of textual records

\section{Scope and content:}

Series consists of professional correspondence pertaining to the lives and careers of members of the Fairlie family.

\section{Notes:}

Arrangement:

Arranged chronologically by archivist. 


\section{File list:}

\begin{tabular}{|c|c|c|c|c|}
\hline FILE TITLE & $\begin{array}{l}\text { START } \\
\text { DATE }\end{array}$ & $\begin{array}{l}\text { END } \\
\text { DATE }\end{array}$ & CONTENTS & $\begin{array}{l}\text { BOX- } \\
\text { FOLDER \# }\end{array}$ \\
\hline $\begin{array}{l}\text { Professional } \\
\text { correspondence }\end{array}$ & 1911 & 1981 & $\begin{array}{l}\text { File contains correspondence regarding } \\
\text { employment, letters pertaining to banking and } \\
\text { adoption, an acceptance letter addressed to } \\
\text { Alan from the National Geographic Society, as } \\
\text { well as various thank you cards to Alan for his } \\
\text { photography contributions to the Canadian } \\
\text { National Railway and the Upper Canada } \\
\text { Railway. }\end{array}$ & $1-3$ \\
\hline
\end{tabular}

\section{SERIES 3: FINANCIAL AND LEGAL DOCUMENTS}

\section{Dates of creation:}

$1916-1962$

\section{Extent:}

$2.5 \mathrm{~cm}$ of textual records

\section{Scope and content:}

Series consists of financial documents and legal records pertaining to members of the Fairlie family, including adoption records, baptism certificates, estate appraisal, and property records.

\section{Notes:}

Arrangement:

Arranged chronologically by archivist. Some materials have remained in their original envelopes.

\section{File list:}

\begin{tabular}{|c|c|c|c|c|}
\hline FILE TITLE & $\begin{array}{l}\text { START } \\
\text { DATE }\end{array}$ & $\begin{array}{l}\text { END } \\
\text { DATE }\end{array}$ & CONTENTS & $\begin{array}{l}\text { BOX- } \\
\text { FOLDER \# }\end{array}$ \\
\hline Legal records & 1916 & 1961 & $\begin{array}{l}\text { File consists of legal records, including } \\
\text { handwritten testimonies by Reverend John } \\
\text { Fairlie and Louis J. Fitzpatrick, adoption } \\
\text { records for Alan and Joyce Fairlie, baptism } \\
\text { certificates, and an original copy of Anne } \\
\text { Louise Fairlie's will. }\end{array}$ & $1-4$ \\
\hline $\begin{array}{l}\text { Financial } \\
\text { documents }\end{array}$ & 1944 & 1962 & $\begin{array}{l}\text { File consists of a Toronto burial grounds deed, } \\
\text { miscellaneous checks and receipts, and an } \\
\text { estate inventory and valuation of the Fairlie's } \\
\text { home on Shorncliffe Ave. conducted in } 1944 \text {. }\end{array}$ & $1-5$ \\
\hline
\end{tabular}




\section{SERIES 4: NEWSPAPERS AND CLIPPINGS}

Dates of creation:

$1911-1986$

\section{Extent:}

$11.4 \mathrm{~cm}$ of textual records

\section{Scope and content:}

Series consists of newspapers, articles, and clippings relating to the personal and professional lives of members of the Fairlie family, including articles written on the Ontario mining industry, obituaries, advertisements, and other articles.

Notes:

Arrangement:

Arranged chronologically by archivist.

File list:

FILE TITLE

START

END

CONTENTS

BOXDATE

DATE

FOLDER \#

Newspaper

1911

1944

Newspaper clippings include the following:

$1-6$

clippings

Matthew and Anne Louise Fairlie's wedding notice, Kennecott Mines Co. article, 2 copies of

The Nugget mining newspaper, multiple copies of Matthew F. Fairlie's obituary from numerous newspapers.

Newspaper

1950

1986

File contains a copy of The Varsity discussing

$1-7$

clippings Monarch Productions Ltd., articles on Queen's mining graduates, clippings of Alan Fairlie's photography as featured in a number of publications, and various miscellaneous articles.

\section{SERIES 5: PHOTOGRAPHIC MATERIALS}

\section{Dates of creation:}

1894 - [ca. 1975]

\section{Extent:}

82 photographs (47 prints, 34 negatives, 1 slide) 


\section{Scope and content:}

Series consists of photographs taken by and of the Fairlie family, including professional studio portraits, photographs taken on film sets, photographic travel negatives, and other miscellaneous photographs and negatives.

\section{Notes:}

Arrangement:

Arranged chronologically by archivist.

Series contains oversized materials that have been stored separately.

Physical condition:

Deterioration and fading to some photographs as noted.

\section{File list:}

\begin{tabular}{|c|c|c|c|c|}
\hline FILE TITLE & $\begin{array}{l}\text { START } \\
\text { DATE }\end{array}$ & $\begin{array}{l}\text { END } \\
\text { DATE }\end{array}$ & CONTENTS & $\begin{array}{l}\text { BOX- } \\
\text { FOLDER \# }\end{array}$ \\
\hline $\begin{array}{l}\text { Photographs and } \\
\text { negatives }\end{array}$ & [ca. 1930] & [ca. 1975] & $\begin{array}{l}60 \text { photographs : } 25 \text { prints, } 34 \text { negatives, } 1 \\
\text { transparency. File consists of a black and white } \\
\text { snapshot of Alan F. Fairlie as a young boy, } \\
\text { black and white negatives taken at Camp } \\
\text { Temagami, colour negatives taken at an } \\
\text { unidentified amusement park, black and white } \\
\text { photographs taken by Alan Fairlie while } \\
\text { filming, miscellaneous negatives from various } \\
\text { travel destinations, and an Ektachrome slide of } \\
\text { Alan with his camera. }\end{array}$ & $1-8$ \\
\hline $\begin{array}{l}\text { Mounted } \\
\text { photographs and } \\
\text { studio portraits } \\
\text { [oversize] }\end{array}$ & 1930 & 1947 & $\begin{array}{l}13 \text { photographs : studio portraits and mounted } \\
\text { photographs of family members taken at } \\
\text { various professional studios in Toronto. }\end{array}$ & 3 \\
\hline $\begin{array}{l}\text { Mounted } \\
\text { photographs and } \\
\text { studio portraits } \\
\text { [oversize] }\end{array}$ & 1894 & 1947 & $\begin{array}{l}9 \text { photographs : studio portraits and mounted } \\
\text { photographs of family members including the } \\
\text { following: Matthew and Anne Louise Fairlie, } \\
\text { Alan and Susanne, Matthew F. Fairlie's class } \\
\text { portrait (image suffering from fading and } \\
\text { spotting), and a mounted photograph of the } \\
\text { Fairlie's home on Shorncliffe Ave. }\end{array}$ & 4 \\
\hline
\end{tabular}

\section{SERIES 6: AMATEUR FILM EPHEMERA}

\section{Dates of creation:}

$1944-[1960$ ?] 


\section{Extent:}

$1.5 \mathrm{~cm}$ of textual records

1 banner : canvas, blue and white (director's chair panel)

\section{Scope and content:}

Series consists of documents and materials related to Alan F. Fairlie's film career, including film advertisements, movie scripts, notes, and film posters.

Notes:

Arrangement:

Arranged chronologically by archivist.

\section{File list:}

FILE TITLE

\section{START}

DATE

\section{END}

DATE

Film ephemera

[1960?]

\section{CONTENTS}

BOX-

FOLDER \#

File consists of 5 poster advertisements for films made by Alan F. Fairlie, film and casting notes, Monarch Productions Ltd. constitution, various bulletins and programs, and 1 canvas director's chair panel.

\section{SERIES 7: MEMORABILIA AND PERSONAL EFFECTS}

\section{Dates of creation:}

[ca. 1900] - 1978

\section{Extent:}

$10.1 \mathrm{~cm}$ of textual records

5 souvenirs (collectibles and other materials)

\section{Scope and content:}

Series consists of travel souvenirs and objects pertaining to members of the Fairlie family. Personal belongings include passports, personal travel diary and notebooks, various drawings and school workbooks, brochures, and miscellaneous collected materials.

\section{Notes:}

Arrangement:

Arranged chronologically by archivist. 
File list:

\begin{tabular}{|c|c|c|c|c|}
\hline FILE TITLE & $\begin{array}{l}\text { START } \\
\text { DATE }\end{array}$ & $\begin{array}{l}\text { END } \\
\text { DATE }\end{array}$ & CONTENTS & $\begin{array}{l}\text { BOX- } \\
\text { FOLDER \# }\end{array}$ \\
\hline $\begin{array}{l}\text { Personal } \\
\text { belongings }\end{array}$ & [ca. 1900] & [ca. 1932] & $\begin{array}{l}\text { File includes souvenirs, brochures, and } \\
\text { notebooks collected and compiled by members } \\
\text { of the Fairlie family. }\end{array}$ & $2-1$ \\
\hline $\begin{array}{l}\text { Personal } \\
\text { belongings }\end{array}$ & 1932 & 1964 & $\begin{array}{l}\text { File consists of Alan F. Fairlie's school puzzle } \\
\text { book, his travel diary, and various brochures. }\end{array}$ & $2-2$ \\
\hline $\begin{array}{l}\text { Personal } \\
\text { belongings }\end{array}$ & 1964 & 1978 & $\begin{array}{l}\text { File consists of memorial records for Anne } \\
\text { Louise Fairlie, excerpts from miscellaneous } \\
\text { novels, a yearbook, and } 2 \text { of Alan F. Fairlie's } \\
\text { passports. }\end{array}$ & $2-3$ \\
\hline $\begin{array}{l}\text { Personal } \\
\text { belongings }\end{array}$ & [19--] & & $\begin{array}{l}\text { File consists of childhood keepsakes, an } \\
\text { address book, and a collected World War I } \\
\text { Canadian Corps telegram. }\end{array}$ & $2-4$ \\
\hline
\end{tabular}




\section{Bibliography}

Abel, Kerry. Changing Places: History, Community and Identity in Northeastern Ontario. London: McGill-Queen's University Press, 2006.

Angus, Charlie and Brit Griffin. We Lived a Life and Then Some: The Life, Death, and Life of a Mining Town. Toronto: Between the Lines Publishing, 1996.

Barthes, Roland. Camera Lucida: Reflections on Photography. Translated by Richard Howard. New York: Hill and Wang, 1980.

Bassnett, Sarah. Picturing Liberalism: Photography and the Making of Modern Toronto. Montreal: McGillQueen's University Press, forthcoming.

Batchen, Geoffrey. Each Wild Idea: Writing, Photography, History. Cambridge: MIT Press, 2002.

---. Forget Me Not: Photography and Remembrance. Cambridge: MIT Press, 2006.

Boerdam, Jaap and Warna Oosterbaan Martinius. "Family Photographs - A Sociological Approach," The Netherlands Journal of Sociology, v16, n2, (Oct, 1980): 95-119.

Bothwell, Robert. A Short History of Ontario. Edmonton: Hurtig Publishers Ltd., 1986.

Bourdieu Pierre et. al, Photography: A Middle-brow Art. Translated by Shaun Whiteside.

Cambridge, UK: Polity Press, 1990 (1965).

Braive, Michael Francois. The Era of the Photograph: A Social History. London: Thames and Hudson, 1966.

Bureau of Canadian Archivists, Rules for Archival Description. Ottawa: Bureau of Canadian Archivists, 1990.

Carmichael, David W. Organizing Archival Records. Lanham: Altamira Press, 2012.

Carter, Rodney G.S. "Photography and Personal Mythology" Queen's Quarterly. Winter 2007 vol. 114 no. 4 , p. 559-569.

Chalfen, Richard. Snapshot Versions of Life. London: Popular Press, 2009.

Chambers, Deborah. "Family as Place: Family Photograph Albums and the Domestication of Public and Private Space" in Picturing Place: Photography and the Geographical Imagination. Schwartz, Joan M. and James R. Ryan, eds. New York: I.B. Tauris Co Ltd, 2003.

Close, Susan. Framing Identity: Social Practices of Photography in Canada. Winnipeg: Arbeiter Ring Publishing, 2008.

Coe, Brian and Paul Gates. The Snapshot Photograph: The Rise of Popular Photography, 18881939. London: Ash \& Grant Publishing, 1977. 
Comacchio, Cynthia R. The Dominion of Youth: Adolescence and the Making of a Modern Canada, 1920-1950. Waterloo: Wilfred Laurier University Press, 2008.

----. The Infinite Bonds of Family: Domesticity in Canada, 1850-1940. Toronto, ON: University of Toronto Press, 1999.

Curtis, Verna Posever. Photographic Memory: The Album in the Age of Photography. New York: Aperture, Library of Congress, 2011.

Dahlgren, Anna. "Dated Photographs: The Personal Photo Album as Visual and Textual Medium." Photography and Culture 3.2 (2010): 175-94.

Dennis, Richard. Cities in Modernity: Representations and Productions of Metropolitan Space, 1840-1930. Cambridge, 2008.

Edwards, Elizabeth, and Janice Hart. Photographs Objects Histories: On the Materiality of Images. London: Routledge, 2004.

Ericksen, Hillary and Ingrid Unger, eds. The Small Museums Cataloguing Manual: A Guide to Cataloguing Object and Image Collections. Victoria: Museums Australia [Victoria], 1990.

Finn, Chris. "Connections: Ansel Adams, Edward Burtynsky and the Group of Seven.” Kleinburg: McMichael Canadian Art Collection, 2013. Web.

Ford, Colin, and Karl Steinorth. You Press the Button, We Do the Rest: The Birth of Snapshot Photography. London: D. Nishen in association with the National Museum of Photography, Film and Television, 1988.

Fox, Michael J. and Peter L. Wilkerson. Introduction to Archival Organization and Description. Edited by Susanne R. Warren. Los Angeles: Getty Information Institute, 1998.

Gardener, Saundra. "Exploring the Family Album: Social Class Differences in Images of Family Life." Sociological Inquiry 62.1 (1991): 245-51.

Grace, Sherrill E. Canada and the Idea of North. Toronto: University of Toronto, 2002.

Greenough, Sarah, Diane Waggoner, Sarah Kennel, and Matthew S. Witkovsky. The Art of the American Snapshot, 1888-1978: from the collection of Robert E. Jackson. Washington: National Gallery of Art, 2007.

Hansen, Judith O'Toole. Different Views in Hudson River School Painting. New York: Columbia University Press, 2008.

Heiferman, Marvin. Now Is Then: Snapshots from the Maresca Collection. New York: Princeton Architectural Press Ltd., 2008.

Hirsch, Julia. Family Photographs: Content, Meaning, and Effect. New York and Oxford: Oxford University Press, 1981. 
Hirsch, Marianne. Family Frames: Photography, Narrative, and Postmemory. Cambridge, MA: Harvard University Press, 1997.

Hirsch, Marianne, ed. The Familial Gaze. Hanover and London: Dartmouth College, 1999.

Hunter, Gregory S. Developing and Maintaining Practical Archives: A How-To-Do-it Manual, $2^{\text {nd }}$ ed. New York: Neal-Schuman Publishers, INC., 2003.

Innis, Harold A. "Settlement and the Mining Frontier." Canadian Frontiers of Settlement, Volume 9, edited by William A. Mackintosh and W.L.G. Joerg. Toronto: Macmillan, 1936.

Ingelevics, Vid. "Damage Done: Materializing the Photographic Image" in Prefix Photo no. 11 (Spring/Summer 2005): 36-49.

Jacobs, David L. "Domestic Snapshots: Toward a Grammar of Motives," Journal of American Culture 4 (Spring 1981): 96.

Jansen, Patrica. Wild Things: Nature, Culture and Tourism in Ontario, 1790-1914. Toronto: University of Toronto Press, 1995.

Kaplan, Louis. American Exposures: Photography and Community in the Twentieth Century. Minneapolis: University of Minnesota Press, 2005.

Kramer, Steven. "Robert C. Kraut's Japan : Cataloguing and Contextualizing post-World War Two Photographic Albums of Japan and the South Pacific." Master's thesis. Ryerson University, 2013.

Krentz, Anna. "Snapshots with an Edge: A Study of Deckled Edge in the North American Snapshot.” Master's thesis. Ryerson University, 2014.

Kuhn, Annette. Family Secrets: Acts of Memory and Imagination. London: Verso, 2002.

Langford, Martha and McCord Museum of Canadian History. Suspended Conversations: The Afterlife of Memory in Photographic Albums. Montreal: McGill-Queen's University Press, 2001.

---. "Telling Pictures and Showing Stories: Photographic Albums in the Collection of the McCord Museum of Canadian History." Montreal: McCord Museum of Canadian History, 2005.

Levine, Barbara and Stephanie Snyder. Snapshot Chronicles: Inventing the American Photo Album. New York: Princeton Architectural Press, 2006.

Lomore, Cassie. "Finding Oceania: Organizing a Collection of Oceanic Photographs and Albums at the Art Gallery of Ontario." Master's thesis. Ryerson University, 2012.

Manco, Sara L. "Finding Wolff: Intellectually Arranging the Werner Wolff Fonds at the Ryerson Image Centre.” Mater's thesis. Ryerson University, 2012. 
McAllister, Danielle. "A Tour Through Scotland: A Finding Aid of Scottish Travel Photography at the Archives \& Special Collections, University of Guelph.” Master's thesis. Ryerson University, 2010.

Motz, Marilyn F. "Visual Autobiography: Photograph Albums of Turn-of-the-Century Midwestern Women." American Quarterly, vol. 41, no. 1 (Mar., 1989): 63-92.

Nelles, H.V. The Politics of Development: Forests, Mines, and Hydroelectric Power in Ontario, 1849-1941. Kingston: McGill-Queen's University Press, 2005.

Nickel, Douglas R. Snapshots: The Photography of Everyday Life, 1888 to the Present. San Francisco: San Francisco Museum of Modern Art, 1998.

Note, Margot. Managing Image Collections: A Practical Guide. United Kingdom: Chandos Publishing, 2011.

O'Brien, Jeff. Basic RAD: An Introduction to the preparation of fonds- and series-level descriptions using the Rules for Archival Description. Regina: The Saskatchewan Council of Archives, 1997.

O'Brien, John and Peter White, eds. Beyond Wilderness: The Group of Seven, Canadian Identity, and Contemporary Art. Montreal: McGill-Queen’s University Press, 2007.

Ott, Katherine. "An Introduction to the History of Scrapbooks" in Katherine Ott, Susan Tucker, and Patricia Buckler, eds., Scrapbooks in American Life (Philadelphia: Temple University Press, 2006): $1-25$.

Parsons, Sarah. "Public/Private Tensions in the Photography of Sally Mann." History of Photography 32.8 (2008): 123-36.

Payne, Carol. The Official Picture: The National Film Board of Canada's Still Photography Collection and the Image of Canada, 1941-1971. Montreal: McGill-Queen’s Press, 2013.

Reiakyam, Oddlaug. "Reframing the Family Photograph.” The Journal of Popular Culture, vol. 25, issue 4, (March 1993): 29-68.

Rigg, Heather. "The Public Lives of Private Family Albums: A Case Study in Collections and Exhibitions at the Art Gallery of Ontario and Max Dean : Album.” Mater's thesis. Ryerson University, 2012.

Ritzenthaler, Mary Lynn and Diane Vogt-O’Connor, Helena Zinkham, Brett Carnell, and Kit Peterson. Photographs: Archival Care and Management. Chicago: Society of American Archivists, 2006.

Rose, Gillian. Doing Family Photography: The Domestic, The Public, and the Politics of Sentiment. London: Ashgate, 2010.

---. "Family Photographs and Domestic Spacings.” Transactions of the Institute of British Geographers 28.1 (2003): 5-18.

Sandbye, Mette. "Looking at the Family Photo Album: A Resumed Theoretical Discussion of Why and How." Journal of Aesthetics \& Culture, 6 (2014). Web. 28 Apr. 2015.

Sarvas, Risto and David M. Frohlich. From Snapshots to Social Media: The Changing Picture of Domestic Photography. New York: Springer, 2011. 
Schwartz, Joan M. and James R. Ryan, eds. Picturing Place: Photography and the Geographical Imagination. New York: I.B. Tauris Co Ltd, 2003.

Siegel, Elizabeth. Galleries of Friendship and Fame: The History of Nineteenth Century American Photograph Albums. Connecticut: Yale University Press, 2010.

Spence, Joe and Patricia Holland. Family Snaps: The Meanings of Domestic Photography. London: Virago Press Limited, 1991.

Stewart, Susan. On Longing: Narratives of the Miniature, the Gigantic, the Souvenir, the Collection. Durham: Duke University Press, 1993.

Stokes, Philip. "The Family Photograph Album So Great a Cloud of Witnesses," in The Portrait Photograph, ed. Graham Clarke. Seattle: University of Washington Press, 1992.

Theimer, Kate, ed. Description: Innovative Practices for Archives and Special Collections. Maryland: Rowman \& Littlefield, 2014.

Waldie, D.J. Close to Home: An American Album. Los Angeles: Getty Publications, 2004.

Wall, Sharon. The Nurture of Nature: Childhood, Antimodernism, and Ontario Summer Camps, 1920-55. Vancouver: UBC Press, 2009.

Walsh, John C. and James Opp. Home, Work, and Play: Situating Canadian Social History. $2^{\text {nd }}$ ed. Toronto: Oxford University Press, 2010.

Waters, Kelly. "Alan Takes Scooter on That Final Ride." Salt Spring News, 2001.

West, D.A. "Re-searching the North in Canada: An Introduction to the Canadian Northern Discourse," Journal of Canadian Studies 26, 2 (1991): 108-19.

Williams, Charles. “The Meaning of Family Photographs.” Web. 1997.

Zuromskis, Catherine. Snapshot Photography: The Lives of Images. Cambridge: MIT Press, 2013. 